\title{
A Luminescent Zirconium(IV) Complex as a Molecular Photosensitizer for Visible Light Photoredox Catalysis.
}

\author{
Yu Zhang, Jeffrey L. Petersen and Carsten Milsmann* \\ C. Eugene Bennett Department of Chemistry, West Virginia University, 100 \\ Prospect Street, Morgantown, West Virginia 26506, United States
}

camilsmann@mail.wvu.edu

Supporting Information 


\section{Contents}

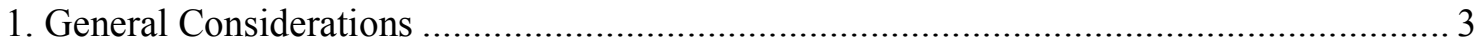

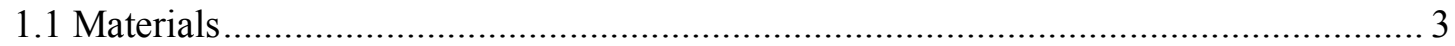

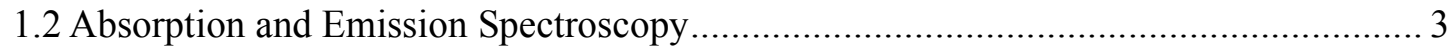

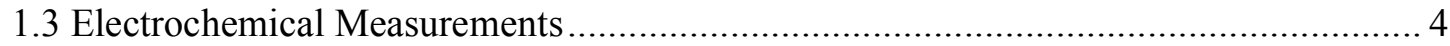

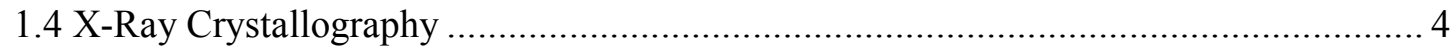

2. Experimental Procedures and Spectroscopic Data......................................................... 5

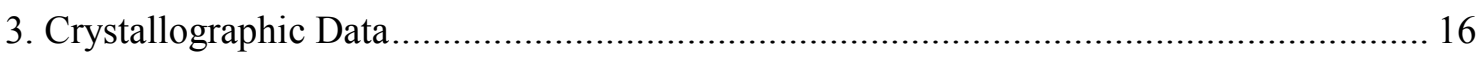

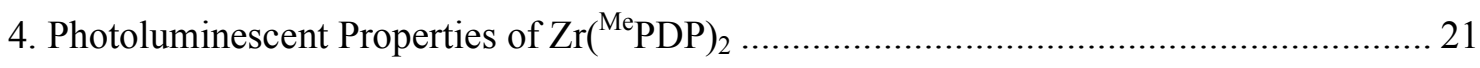

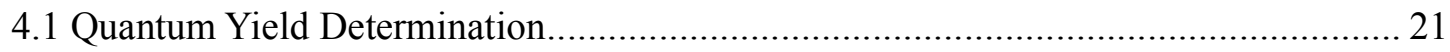

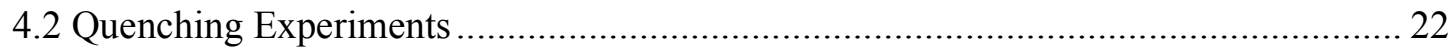

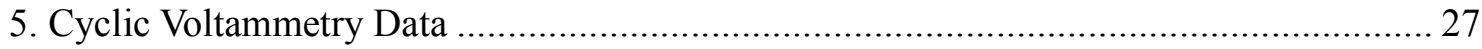

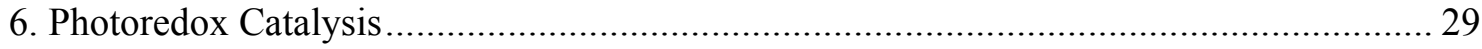

6.1 Experimental Setup for Photoredox Reactions....................................................... 30

6.2 Photoredox-Catalyzed Debromination of Ethyl Bromodifluoroacetate....................... 31

6.3 Reduction of Diethyl Maleate using Photoredox Catalysis ..................................... 36

6.4 Reductive Coupling of Benzyl Bromide using Photoredox Catalysis ......................... 41

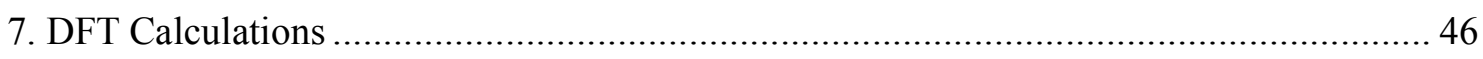

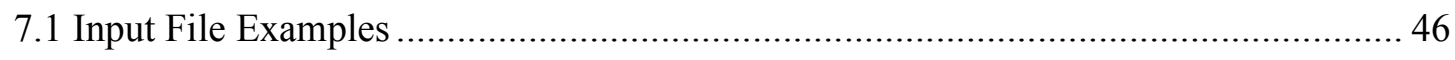

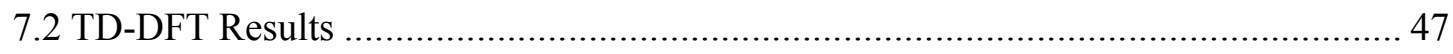

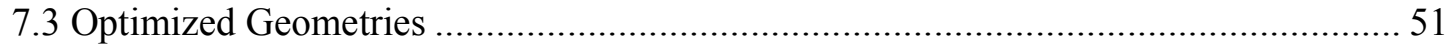

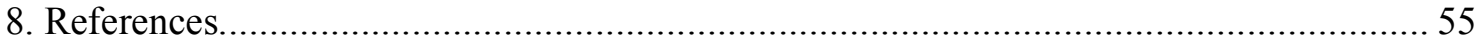




\section{General Considerations}

\subsection{Materials}

All air- and moisture-sensitive manipulations were carried out using standard high vacuum line, Schlenk, or cannula techniques or in an MBraun inert atmosphere drybox containing an atmosphere of purified nitrogen. Solvents for air- and moisture-sensitive manipulations were dried and deoxygenated using a Glass Contour Solvent Purification System and stored over $4 \AA$ molecular sieves. 2,6-Pyridinedimethanol, 4-phenyl-3-buten-2-one, 3-benzyl-5-(2-hydroxyethyl)-4-methylthiazolium chloride, sodium tert-butoxide, 1.6 M $n$-butyllithium solution in hexanes, 1,3,5-trimethoxybenzene, diethyl maleate, ethyl bromodifluoroacetate and iodine were purchased from commercial source. 2,6-Pyridinedicarboxaldehyde, ${ }^{1}$

1,3-dimethyl-2-phenyl-2,3-dihydro-1H-7-methylbenzo-[d]imidazole $\quad\left({ }^{\mathrm{Me}} \mathrm{BIH}\right)^{2-4} \quad$ were prepared following literature procedures. All solids were dried under high vacuum overnight, all liquids were dried over $\mathrm{CaH}_{2}$ for at least two days and vacuum transferred into oven dried glassware in order to bring into the glovebox. High boiling substrates were degassed, dried over $\mathrm{CaH}_{2}$ and filtered through celite in the glovebox. Tetrabutylammonium hexafluorophosphate for electrochemical experiments was ground into a fine power and dried under vacuum at $150{ }^{\circ} \mathrm{C}$ for $48 \mathrm{~h}$ to remove any trace amounts of water. Deuterated solvents for NMR spectroscopy were distilled from sodium metal $\left(\mathrm{C}_{6} \mathrm{D}_{6}\right)$ or $\mathrm{CaH}_{2}\left(\mathrm{CDCl}_{3}\right)$ and stored over $4 \AA$ molecular sieves. ${ }^{1} \mathrm{H}$ and ${ }^{13} \mathrm{C}\left\{{ }^{1} \mathrm{H}\right\} \mathrm{NMR}$ spectra were recorded on an Agilent $400 \mathrm{MHz}$ spectrometer or a Varian INOVA $600 \mathrm{MHz}$ spectrometer. All chemical shifts are reported relative to $\mathrm{SiMe}_{4}$ using ${ }^{1} \mathrm{H}$ (residual) chemical shifts of the solvent as a secondary standard. High resolution mass spectra were obtained on a Thermo Finnigan Linear Trapping Quadrupole mass spectrometer. Melting points were taken on a Mel-Temp ${ }^{\circledR}$ melting point apparatus.

\subsection{Absorption and Emission Spectroscopy}

UV-vis absorption spectra were recorded on a Shimadzu UV-1800 spectrophotometer in gastight quartz cuvettes with a $10 \mathrm{~mm}$ path length fitted with screw caps. Emission spectra were obtained in $10 \mathrm{~mm}$ path length gastight quartz cuvettes with screw caps using a 
Shimadzu RF-5301 PC spectrofluorophotometer.

\subsection{Electrochemical Measurements}

Cyclic voltammetry measurements were conducted under nitrogen atmosphere inside an MBraun drybox using a Gamry Interface 1000 electrochemical workstation in a single compartment cell using $1 \mathrm{mM}$ sample solutions in THF with $0.1 \mathrm{M}$ tetrabutylammonium hexafluorophosphate as supporting electrolyte. A three electrode setup was employed with a glassy carbon electrode as working electrode, a platinum sheet as the counter electrode and a silver wire as a quasi-reference electrode. Ferrocene was added as an internal standard after completion of the measurements and all potentials are referenced versus the $\mathrm{Fc}^{+} / \mathrm{Fc}$ couple.

\subsection{X-Ray Crystallography}

Single crystals suitable for X-ray diffraction were coated with polyisobutylene oil (Sigma-Aldrich) in a drybox, transferred to a nylon loop, and then quickly transferred to the goniometer head of a Bruker AXS D8 Venture fixed-chi X-ray diffractometer equipped with a Triumph monochromator, a Mo Ka radiation source $(1=0.71073 \AA)$, and a PHOTON 100 CMOS detector. The samples were cooled to $100 \mathrm{~K}$ with an Oxford Cryostream 700 system and optically aligned. The APEX2 software program (version 2014.1-1) $)^{5}$ was used for diffractometer control, preliminary frame scans, indexing, orientation matrix calculations, least-squares refinement of cell parameters, and the data collection. Two sets of 12 frames each were collected using the omega scan method with a $10 \mathrm{~s}$ exposure time. Integration of these frames followed by reflection indexing and least-squares refinement produced a crystal orientation matrix for the crystal lattice that was used for the structural analysis. The data collection strategy was optimized for completeness and redundancy using the Bruker COSMO software suite. The space group was identified, and the data were processed using the Bruker SAINT+ program and corrected for absorption using SADABS. The structures were solved using direct methods (SHELXS) completed by subsequent Fourier synthesis and refined by full-matrix least-squares procedures using the programs provided by SHELXL-2014. ${ }^{6}$ 


\section{Experimental Procedures and Spectroscopic Data}

\section{2,6-bis(5-methyl-3-phenyl-1H-pyrrol-2-yl)pyridine $\left(\mathrm{H}_{2}^{\mathrm{Me}} \mathrm{PDP}\right)$ :}

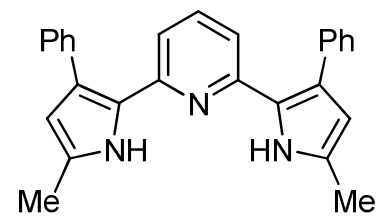

The synthesis was carried out according to a modified literature procedure. ${ }^{7,8}$ 2,6-Pyridinedicarboxaldehyde (3.50 g, $25.90 \mathrm{mmol}, 1.00$ equiv), 4-phenyl-3-buten-2-one (7.65 g, $52.32 \mathrm{mmol}, 2.02$ equiv), and 3-benzyl-5-(2-hydroxyethyl)-4-methyl-thiazolium chloride (4.19 g, $15.54 \mathrm{mmol}, 0.6$ equiv), were mixed in a $250 \mathrm{~mL}$ Schlenk flask under an argon atmosphere. Absolute ethanol was added and the mixture was heated to reflux. A solution of sodium tert-butoxide ( $1.49 \mathrm{~g}, 15.54 \mathrm{mmol}, 0.6$ equiv) in ethanol was added via syringe and heating was continued for 24 hours. The reaction was cooled to room temperature and ammonium acetate $(11.98 \mathrm{~g}, 155.42 \mathrm{mmol}, 6$ equiv) was added to the mixture. The reaction mixture was heated to reflux open to air for 24 hours. The solid precipitate was collected via filtration, washed with ethanol, and dried under high vacuum to yield the desired product as a pale yellow solid (Yield: $3.14 \mathrm{~g}, 31 \%$, one crop). X-ray quality crystals of $\mathrm{H}_{2}{ }^{\mathrm{Me}} \mathrm{PDP}$ were grown from DCM and hexane solution cooled to $4{ }^{\circ} \mathrm{C}$. M.p. $210-212{ }^{\circ} \mathrm{C} .{ }^{1} \mathrm{H}$ NMR (600 MHz, $\left.\mathrm{C}_{6} \mathrm{D}_{6} ; \delta, \mathrm{ppm}\right): 9.59$ (s, 2H, NH), 7.43 (d, J= $7.8 \mathrm{~Hz}$, 4H, $\mathrm{Ph} H), 7.37$ (t, $J=7.8 \mathrm{~Hz}, 4 \mathrm{H}, \mathrm{Ph} H), 7.29$ (tt, $J=7.8,1.8 \mathrm{~Hz}, 2 \mathrm{H}, \mathrm{Ph} H), 7.14$ (t, $J=8.4$ Hz, 1H, PyH), 6.94 (d, $J=8.4$ Hz, 2H, PyH), 5.98 (d, $J=3.0$ Hz, 2H, Pyrrole $H$ ), 2.20 (s, $\left.6 \mathrm{H}, \mathrm{CH}_{3}\right) .{ }^{13} \mathrm{C}$ NMR $\left(151 \mathrm{MHz}, \mathrm{C}_{6} \mathrm{D}_{6} ; \delta, \mathrm{ppm}\right): 150.51,137.69,136.58,129.62,129.40$, 128.56, 126.59, 125.99, 125.29, 116.54, 111.03, 12.88. HRMS (ESI) calcd for $\mathrm{C}_{27} \mathrm{H}_{24} \mathrm{~N}_{3}{ }^{+}$ $[\mathrm{M}+\mathrm{H}]^{+} \mathrm{m} / z$ 390.19647; Found 390.19704. 


\section{$\operatorname{Zr}\left({ }^{\mathrm{Me}} \mathbf{P D P}\right)_{2}$ :}

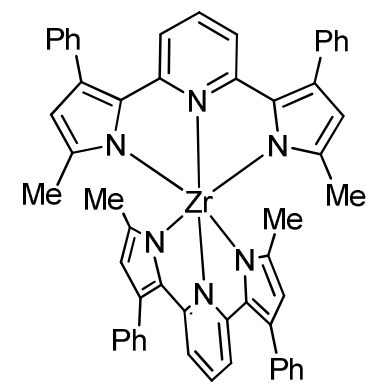

$n$-BuLi (0.972 mL (1.6 M solution in hexanes), $1.56 \mathrm{mmol}, 2.02$ equiv) was added slowly to a $20 \mathrm{~mL}$ vial charged with a solution of $\mathrm{H}_{2}{ }^{\mathrm{Me}} \mathrm{PDP}(300 \mathrm{mg}, 0.770 \mathrm{mmol}, 1.00$ equiv) in 5 $\mathrm{mL}$ of THF. The reaction was stirred for 2 hours at room temperature to generate a luminescent dark green-yellow solution of the deprotonated ligand. A solution of $\mathrm{ZrCl}_{4}(99$ $\mathrm{mg}, 0.424 \mathrm{mmol}, 0.55$ equiv) in $3 \mathrm{~mL}$ of THF was added in small portions to the deprotonated ligand over 1 hour. The reaction mixture was allowed to stir at room temperature and the color of the solution slowly changed to fluorescent red. After 2 days, THF was removed in vacuo. The solid residue was washed three times with benzene to remove any unreacted $\mathrm{Li}_{2}{ }^{\mathrm{Me}} \mathrm{PDP}$ and potential mono-ligated zirconium species. The crude product was redissolved in THF and filtered. Addition of (TMS) $)_{2} \mathrm{O}$ gave the desired product as a red microcrystalline material (Yield: $232 \mathrm{mg}, 69 \%$ ). Anal. Calcd for $\mathrm{C}_{54} \mathrm{H}_{42} \mathrm{~N}_{6} \mathrm{Zr} \cdot{ }^{1} / 2$ (TMS) $)_{2} \mathrm{O}: \mathrm{C}, 72.26 ; \mathrm{H}, 5.43 ; \mathrm{N}, 8.87$. Found: C, 71.91; H, 5.61; N, 8.51. ${ }^{1} \mathrm{H}$ NMR (600 MHz, $\left.\mathrm{C}_{6} \mathrm{D}_{6} ; \delta, \mathrm{ppm}\right): 7.45$ - $7.43(\mathrm{~m}, 8 \mathrm{H}, \mathrm{Ph} H), 7.41$ - $7.38(\mathrm{~m}, 8 \mathrm{H}, \mathrm{Ph} H), 7.32$ (tt, $J=7.8,1.8 \mathrm{~Hz}, 4 \mathrm{H}, \mathrm{Ph} H), 7.15$ (t, $J=8.4 \mathrm{~Hz}, 2 \mathrm{H}, \mathrm{Py} H), 6.81$ (d, $J=8.4 \mathrm{~Hz}, 4 \mathrm{H}, \mathrm{Py} H$ ), $5.79(\mathrm{~d}, J=0.6 \mathrm{~Hz}, 4 \mathrm{H}$, Pyrrole $H), 2.06\left(\mathrm{~s}, 12 \mathrm{H}, \mathrm{CH}_{3}\right) .{ }^{13} \mathrm{C} \mathrm{NMR}\left(151 \mathrm{MHz}, \mathrm{C}_{6} \mathrm{D}_{6} ; \delta, \mathrm{ppm}\right)$ : $154.68,141.77,140.81,136.89,134.85,130.26,129.37,128.57,127.07,113.22,111.89$, 14.58. An alternative way of purification could also be employed: After washing with 
benzene, the crude product was dried in vacuo, redissolved in DCM, and filtered to remove $\mathrm{LiCl}$ and potentially unreacted $\mathrm{ZrCl}_{4}$. Removal of the solvent in vacuo provided a red microcrystalline solid (Yield: $263 \mathrm{mg}, 73 \%$, based on $325 \mathrm{mg}$ ligand scale). The compound was pure based on NMR analysis. Single crystals suitable for X-ray crystallographic analysis were grown by slow diffusion of pentane into a saturated solution of $\operatorname{Zr}\left({ }^{\mathrm{Me}} \mathrm{PDP}\right)_{2}$ in DCM at $-35^{\circ} \mathrm{C}$.

\section{$\left[\mathrm{Li}(\mathrm{THF})_{4}\right]\left[\mathrm{Ti}\left({ }^{\mathrm{Me}} \mathrm{PDP}\right)_{2}\right]$ :}

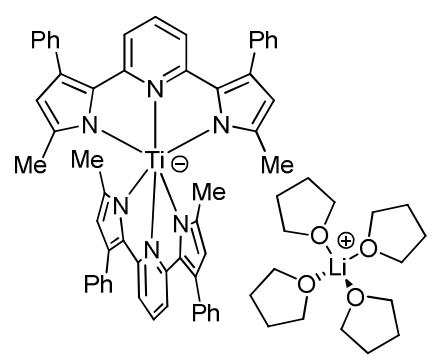

$n$-BuLi (1.16 mL (1.6 M solution in hexanes), $1.86 \mathrm{mmol}, 2.02$ equiv) was added slowly to a $50 \mathrm{~mL}$ thick-walled glass vessel containing a solution of $\mathrm{H}_{2}{ }^{\mathrm{Me}} \mathrm{PDP}(358 \mathrm{mg}, 0.919 \mathrm{mmol}$, 1.00 equiv) in $5 \mathrm{~mL}$ of THF. The reaction was stirred for 2 hours at room temperature to generate a luminescent dark green-yellow solution of deprotonated ligand. A solution of $\mathrm{TiCl}_{3}(\mathrm{THF})_{3}(177 \mathrm{mg}, 0.478 \mathrm{mmol}, 0.52$ equiv) in $3 \mathrm{~mL}$ of $\mathrm{THF}$ was added to the deprotonated ligand in small portions over a period of 1 hour. The thick-walled vessel was sealed with a PTFE screw cap and heated to $75{ }^{\circ} \mathrm{C}$ overnight, resulting in a dark red solution. After cooling to room temperature, the reaction vessel was brought back into the glovebox and the volatiles were removed in vacuo. The residue was redissolved by benzene and filter through celite to remove $\mathrm{LiCl}$. After evaporation of benzene, the crude product was recrystallized from equal amounts of THF and $\mathrm{Et}_{2} \mathrm{O}$ cooled to $-35^{\circ} \mathrm{C}$. The product was collected by filtration as dark purple microcrystals (Yield: $318 \mathrm{mg}, 62 \%$ ). X-ray quality crystals of $\left[\mathrm{Li}(\mathrm{THF})_{4}\right]\left[\mathrm{Ti}\left({ }^{\mathrm{Me}} \mathrm{PDP}\right)_{2}\right]$ were grown from THF and toluene solution cooled to $-35{ }^{\circ} \mathrm{C} .{ }^{1} \mathrm{H}$ NMR (400 MHz, $\left.\mathrm{C}_{6} \mathrm{D}_{6} ; \delta, \mathrm{ppm}\right): 23.39$ (br, 4H), 19.69 (br, 12H), 10.82 (br, 4H), $8.14(\mathrm{~s}, 8 \mathrm{H}), 6.11(\mathrm{~s}, 8 \mathrm{H}), 5.81(\mathrm{~s}, 4 \mathrm{H}), 3.43(\mathrm{~s}, 32 \mathrm{H}$, including extra THF residue), 1.33(s, 
$32 \mathrm{H}$, including extra THF residue), $-34.53(\mathrm{br}, 2 \mathrm{H})$. Multiple attempts to obtain satisfactory elemental analysis have been unsuccessful due to the high sensitivity of the compound.

\section{$\operatorname{Ti}\left({ }^{\mathrm{Me}} \mathrm{PDP}\right)_{2}$ :}

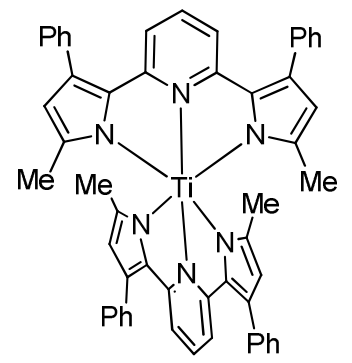

In a $20 \mathrm{~mL}$ vial, a solution of [Li(THF $\left.)_{4}\right]\left[\mathrm{Ti}\left({ }^{\mathrm{Me}} \mathrm{PDP}\right)_{2}\right](140 \mathrm{mg}, 0.125 \mathrm{mmol}, 1.00$ equiv $)$ in $3 \mathrm{~mL}$ of chloroform was treated with iodine ( $16 \mathrm{mg}, 0.063 \mathrm{mmol}, 0.50$ equiv) dissolved in 2 $\mathrm{mL}$ of chloroform. The color of the reaction mixture turned to dark brown immediately and the reaction was allowed to stir at room temperature for 30 mins. The volatiles were removed in vacuo and the resulting solid material was heated to $100{ }^{\circ} \mathrm{C}$ under high vacuum for $8 \mathrm{hrs}$ in order to remove THF that was generated during the reaction. The crude product was redissolved in chloroform and filter through Celite to remove $\mathrm{LiCl}$. The filtrate was dried in vacuo and the product was collected as a dark brown solid (Yield: $95 \mathrm{mg}, 92 \%$ ). X-ray quality crystals of $\mathrm{Ti}\left({ }^{\mathrm{Me}} \mathrm{PDP}\right)_{2}$ were obtained via slow evaporation of THF at room temperature. ${ }^{1} \mathrm{H}$ NMR (600 MHz, $\left.\mathrm{CDCl}_{3} ; \delta, \mathrm{ppm}\right): 7.457 .43$ (m, 8H, $\left.\mathrm{PhH}\right), 7.40-7.37$ (t, $J$ $=7.8 \mathrm{~Hz}, 8 \mathrm{H}, \mathrm{Ph} H$ ), 7.31 (tt, $J=7.8,1.8 \mathrm{~Hz}, 4 \mathrm{H}, \mathrm{Ph} H), 7.10$ (t, $J=7.8 \mathrm{~Hz}, 2 \mathrm{H}, \mathrm{Py} H$ ), 6.72 (d, $J=7.8 \mathrm{~Hz}, 4 \mathrm{H}, \mathrm{Py} H), 5.63$ (s, 4H, Pyrrole $H$ ), 2.08 (s, 12H, $\left.\mathrm{CH}_{3}\right) .{ }^{13} \mathrm{C}$ NMR $(151 \mathrm{MHz}$, $\left.\mathrm{CDCl}_{3} ; \delta, \mathrm{ppm}\right): 155.07,142.42,140.85,136.38,135.26,129.22,128.64,128.56,127.16$, 110.98, 110.90, 15.12. Anal. Calcd for $\mathrm{C}_{54} \mathrm{H}_{42} \mathrm{~N}_{6} \mathrm{Ti}^{2}{ }^{2}{ }_{3} \mathrm{CHCl}_{3}$ : C, 72.76; H, 4.77; N, 9.31; Found: C, 72.51; H, 5.01; N, 9.25. 

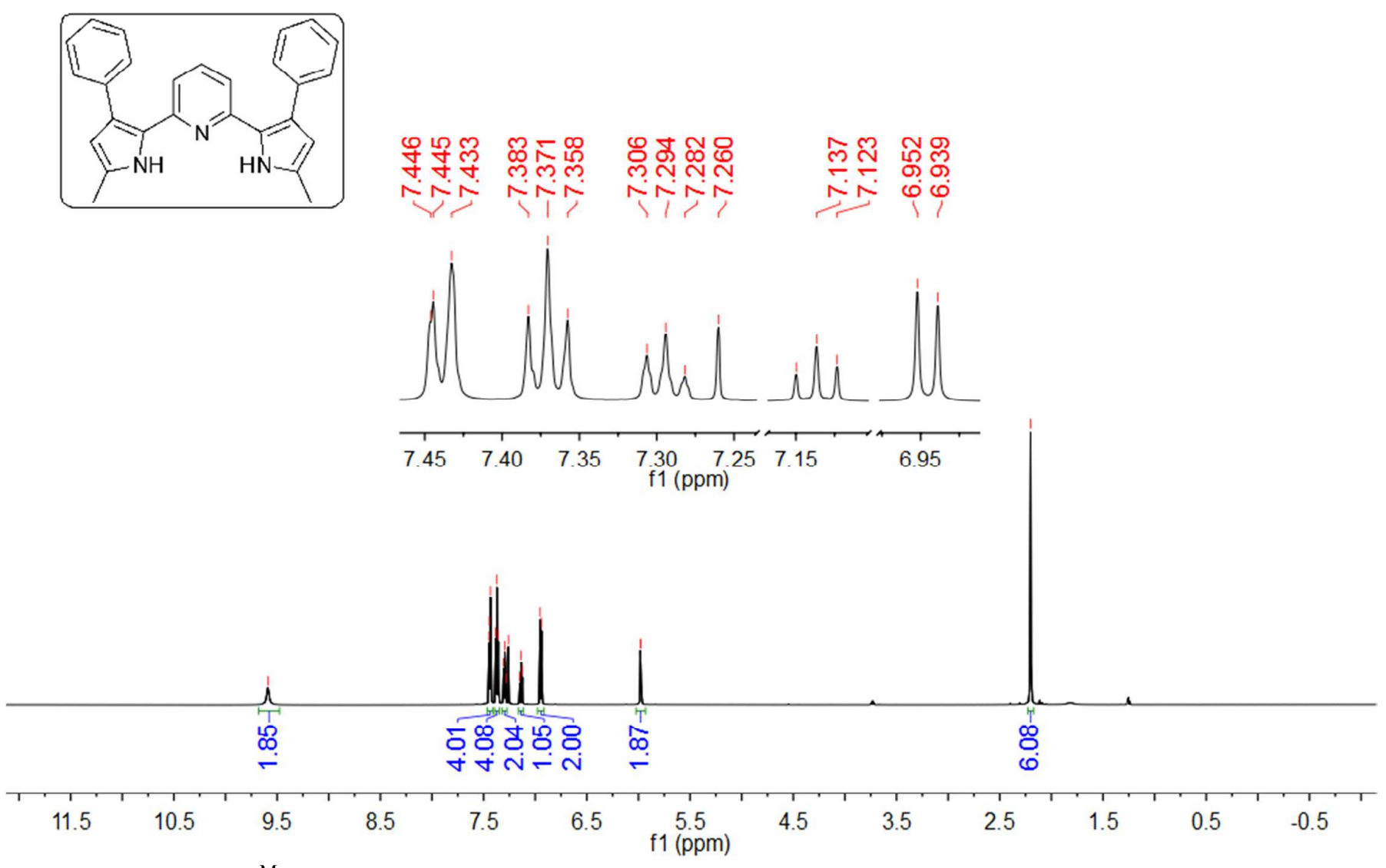

Figure S1. ${ }^{1} \mathrm{H}$ NMR spectrum of $\mathrm{H}_{2}{ }^{\mathrm{Me}} \mathrm{PDP}$ in $\mathrm{CDCl}_{3}$. 

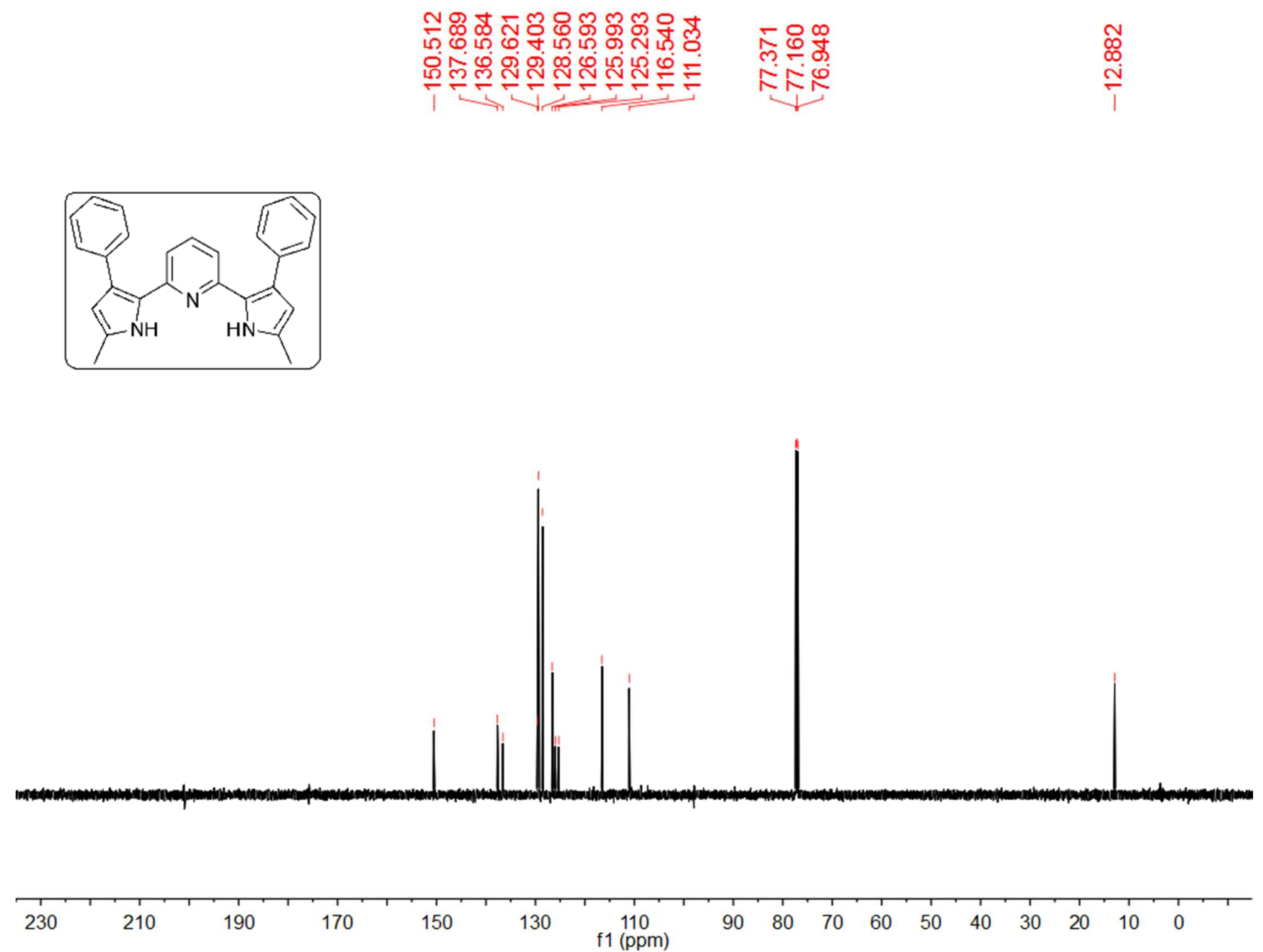

Figure S2. ${ }^{13} \mathrm{C}$ NMR spectrum of $\mathrm{H}_{2}{ }^{\mathrm{Me}} \mathrm{PDP}$ in $\mathrm{CDCl}_{3}$. 


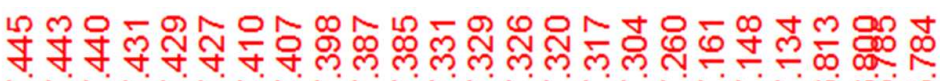

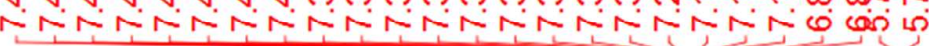

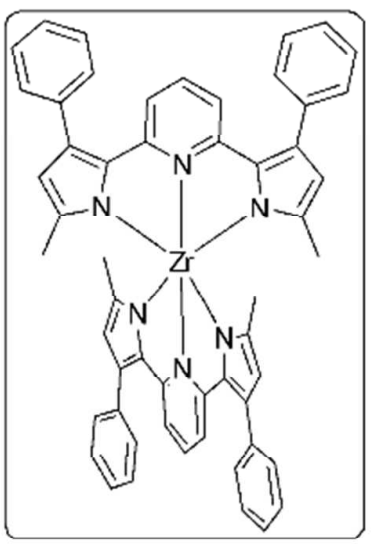

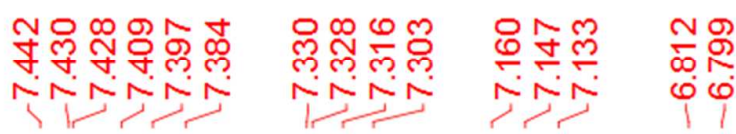
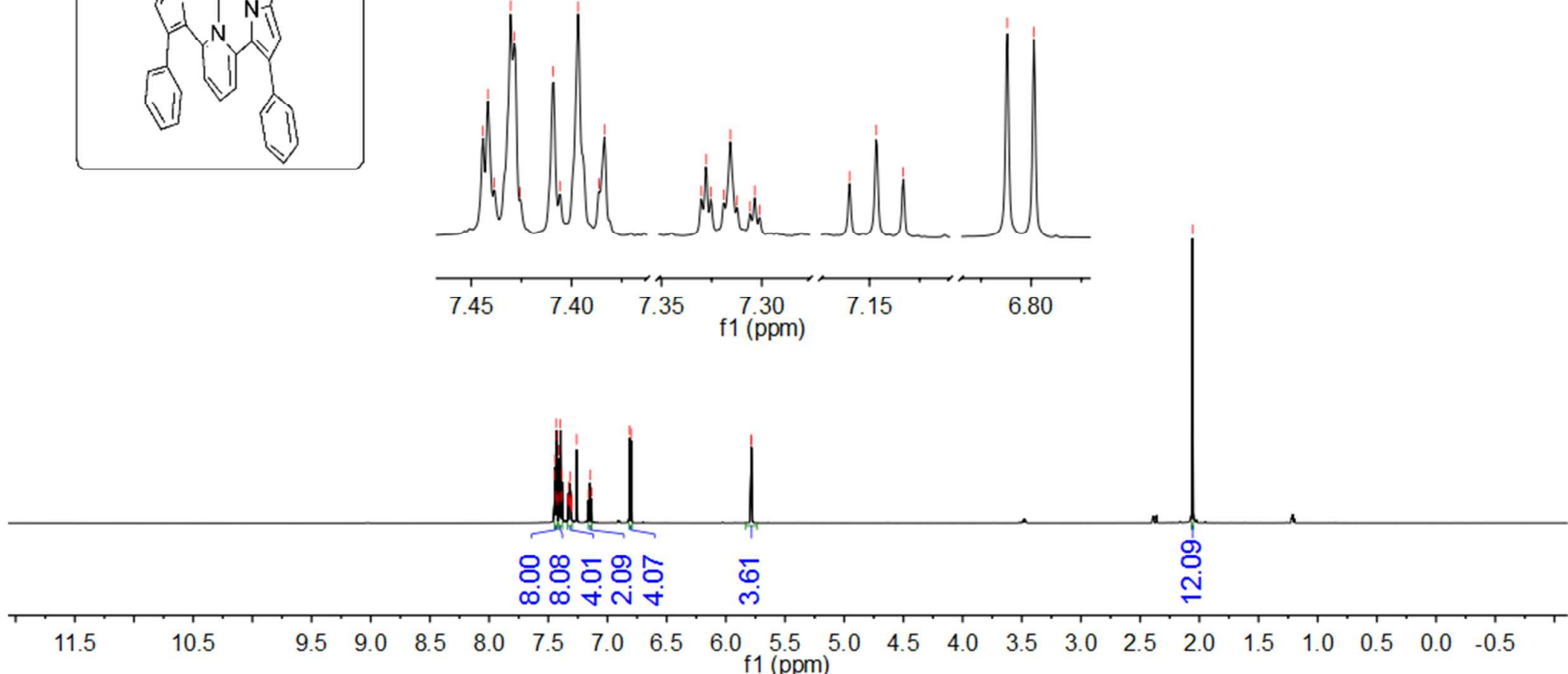

Figure S3. ${ }^{1} \mathrm{H}$ NMR spectrum of $\mathrm{Zr}\left({ }^{\mathrm{Me}} \mathrm{PDP}\right)_{2}$ in $\mathrm{CDCl}_{3}$. 

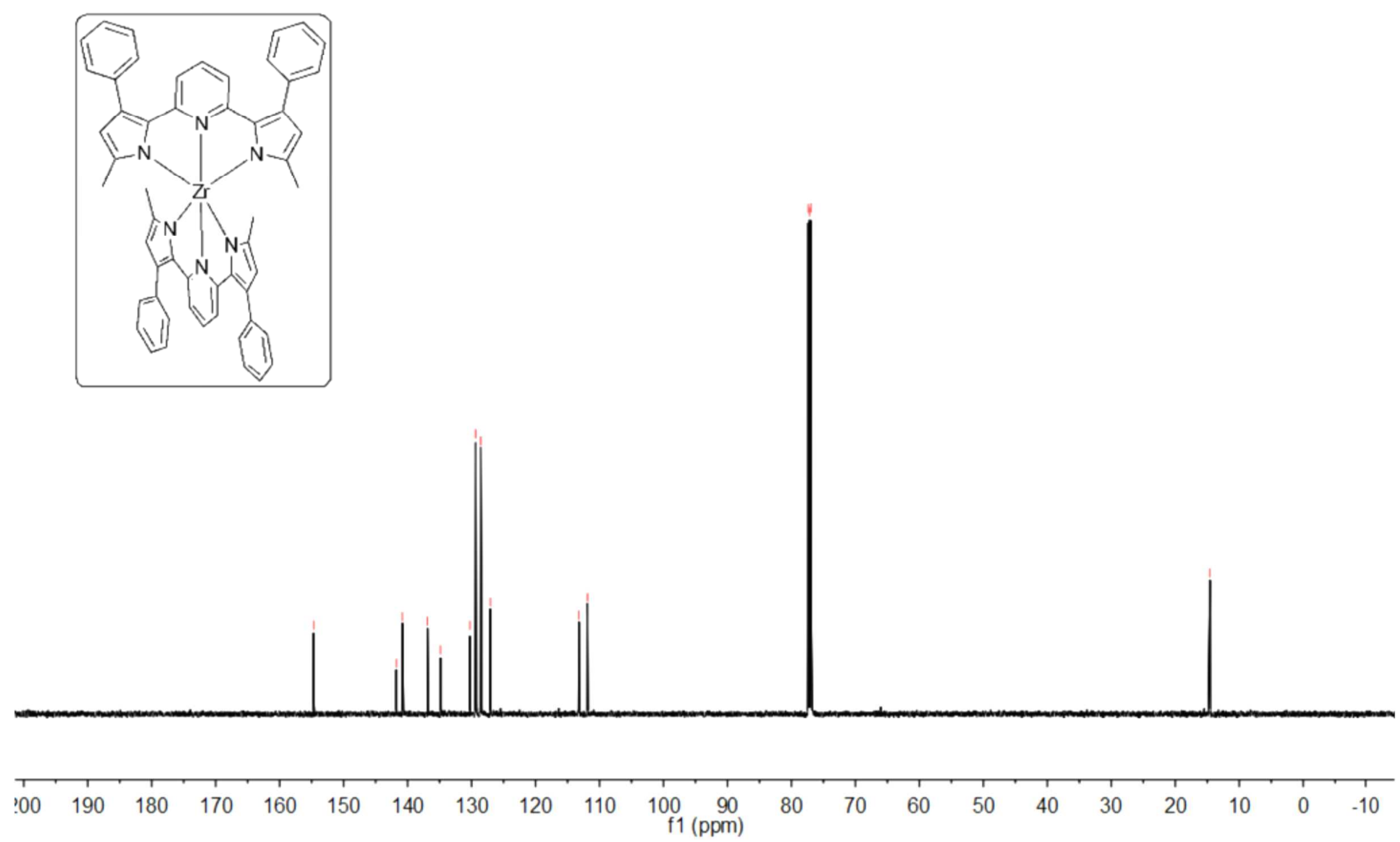

Figure S4. ${ }^{13} \mathrm{C}$ NMR spectrum of $\mathrm{Zr}\left({ }^{\mathrm{Me}} \mathrm{PDP}\right)_{2}$ in $\mathrm{CDCl}_{3}$. 


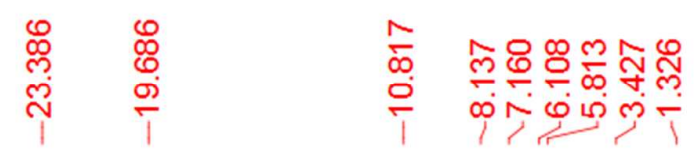
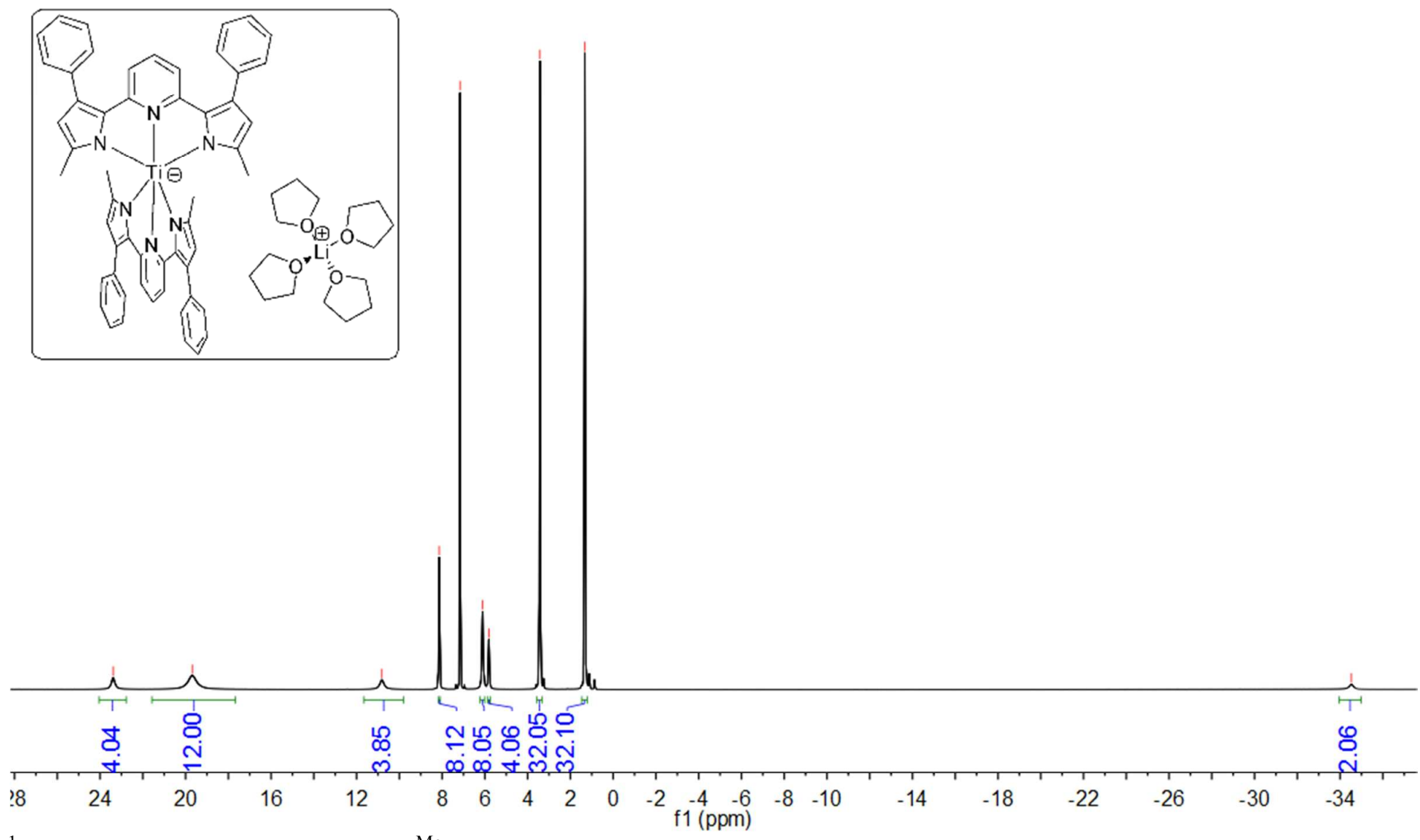

Figure S5. ${ }^{1} \mathrm{H}$ NMR spectrum of $\left[\mathrm{Li}(\text { thf })_{4}\right]\left[\mathrm{Ti}\left({ }^{\mathrm{Me}} \mathrm{PDP}\right)_{2}\right]$ in $\mathrm{C}_{6} \mathrm{D}_{6}$. 

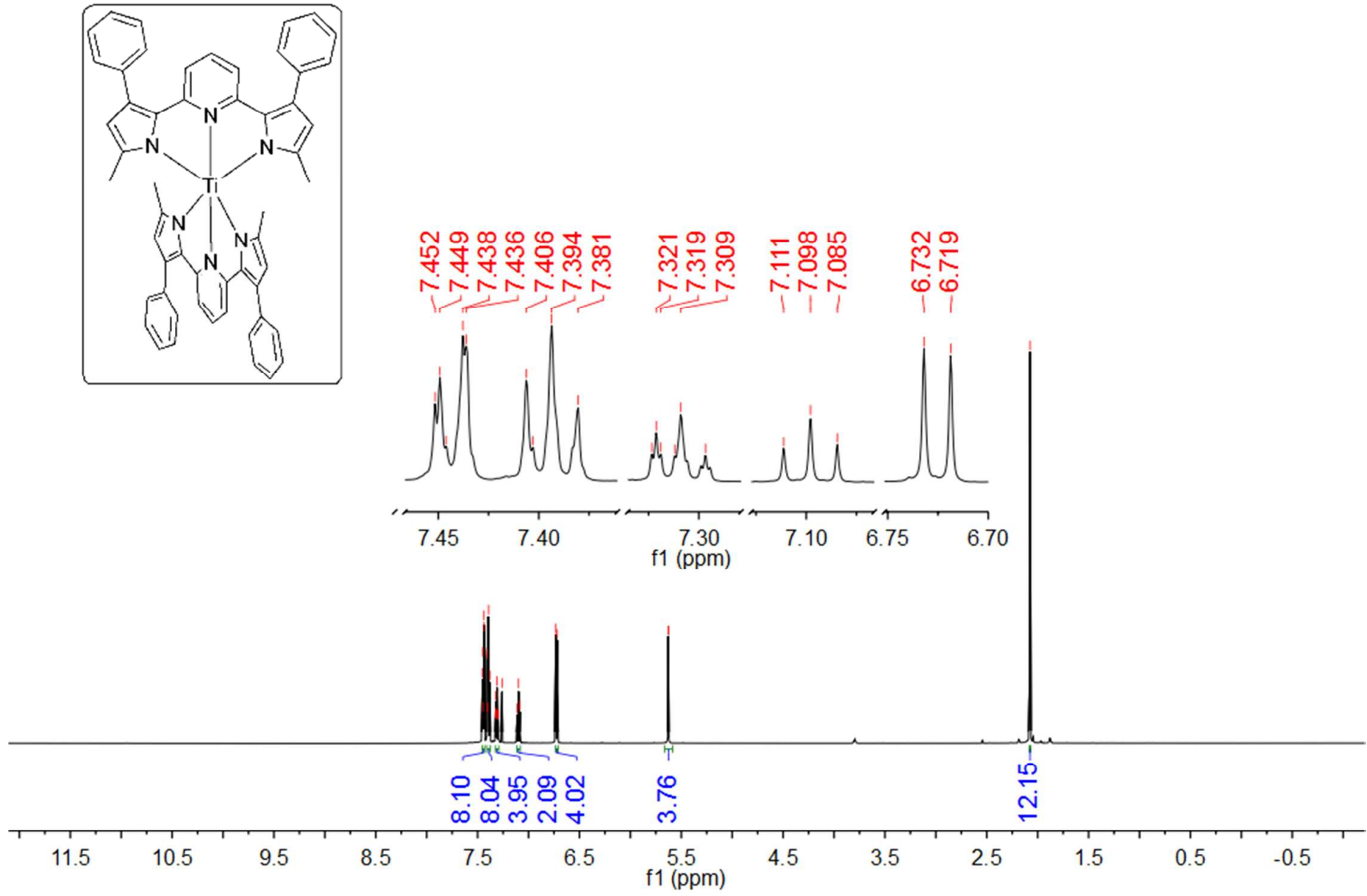

Figure S6. ${ }^{1} \mathrm{H}$ NMR spectrum of $\mathrm{Ti}\left({ }^{\mathrm{Me}} \mathrm{PDP}\right)_{2}$ in $\mathrm{CDCl}_{3}$. 


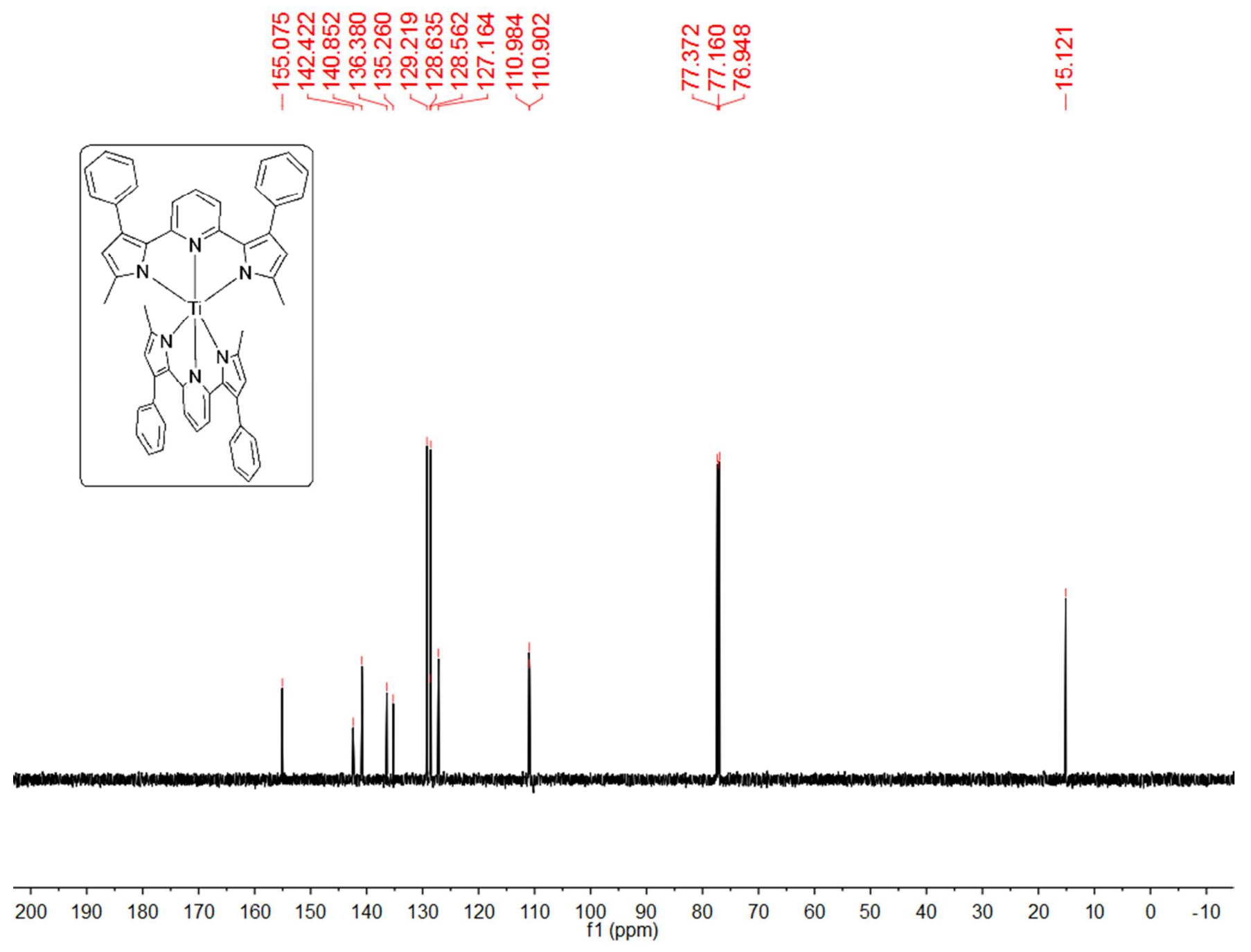

Figure S7. ${ }^{13} \mathrm{C}$ NMR spectrum of $\mathrm{Ti}\left({ }^{\mathrm{Me}} \mathrm{PDP}\right)_{2}$ in $\mathrm{CDCl}_{3}$. 


\section{Crystallographic Data}

\section{$\mathrm{H}_{2}\left({ }^{\mathrm{Me}} \mathrm{PDP}\right)$ :}

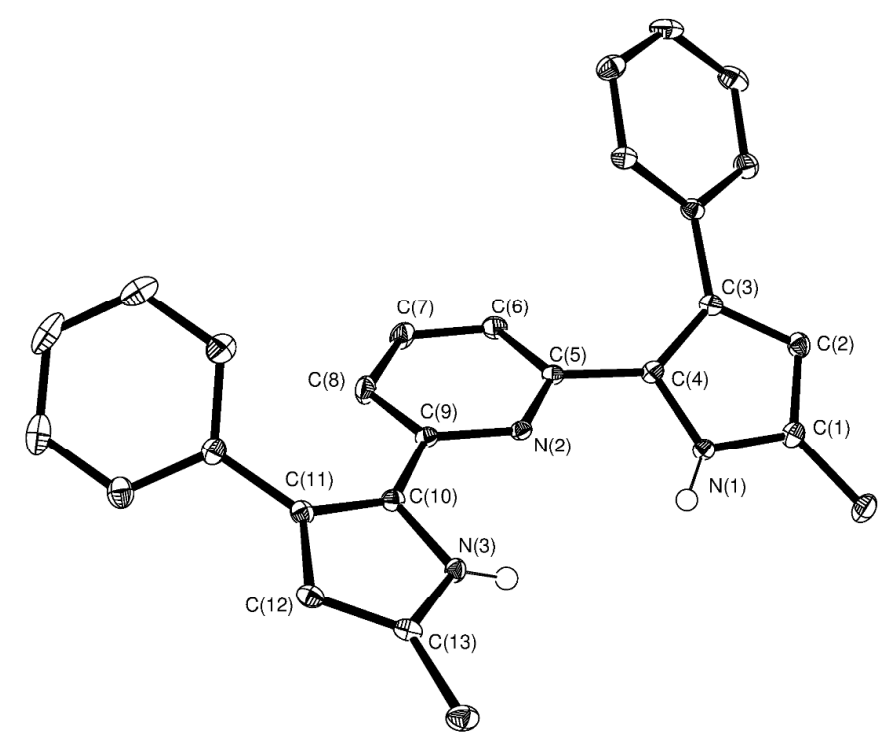

Figure S8. Representation of the molecular structure of $\mathrm{H}_{2}\left({ }^{\mathrm{Me}} \mathrm{PDP}\right)$ with $50 \%$ probability ellipsoids. Hydrogen atoms except for $\mathrm{N}-\mathrm{H}$ hydrogens were omitted for clarity.

\section{$\operatorname{Ti}\left({ }^{\mathrm{Me}} \mathrm{PDP}\right)_{2}$ :}

A THF molecule that lies near a center of inversion is badly disordered and was treated as a diffuse electron density contribution with the aid of the SQUEEZE routine in the program PLATON. ${ }^{9,10}$ Although specific positions for the independent carbon, hydrogen, and oxygen atoms of this disordered THF molecule were not determined, the calculated density, absorption coefficient, and formula weight reflect their presence within the crystal lattice. The empirical formula and empirical formula weight calculated by the CHECKcif program based on one molecule of $\left[\mathrm{C}_{27} \mathrm{H}_{21} \mathrm{~N}_{3}\right]_{2} \mathrm{Ti}$ and one refined molecule of THF are $\mathrm{C}_{58} \mathrm{H}_{50} \mathrm{~N}_{6} \mathrm{OTi}$ and 894.91, respectively, whereas the reported empirical formula weight based on one molecule of $\left[\mathrm{C}_{27} \mathrm{H}_{21} \mathrm{~N}_{3}\right]_{2} \mathrm{Ti}$ and two molecules of THF are $\mathrm{C}_{62} \mathrm{H}_{58} \mathrm{~N}_{6} \mathrm{O}_{2}$ Ti and 967.04, respectively. The greater than $5 \%$ discrepancy between the calculated formula weight (based on the refined atoms in the crystallographic asymmetric unit) and the reported formula weight that includes the THF molecule treated by SQUEEZE produces a Level B alert when CHECKcif is run on the corresponding cif file. The non-hydrogen atoms of the other 
molecule of THF were located and refined anisotropically with the two C-O distances and the three C-C distances restrained at $1.46 \pm 0.02 \AA$ and $1.52 \pm 0.02 \AA$, respectively.

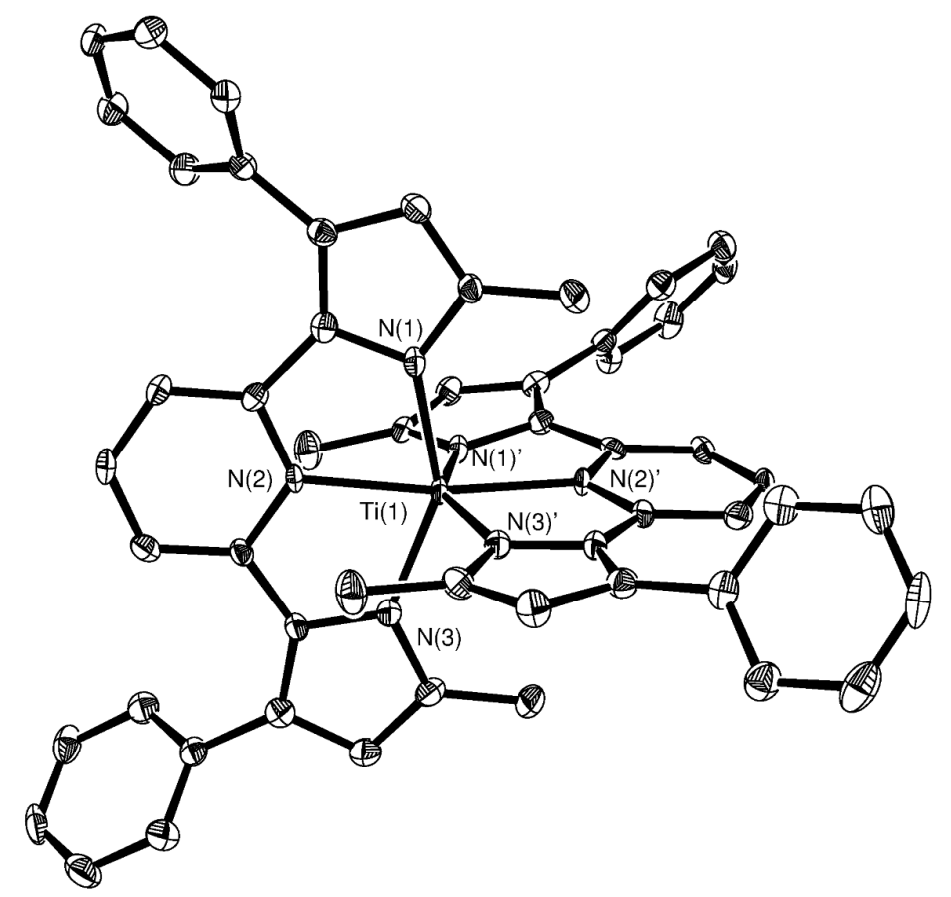

Figure S9. Representation of the molecular structure of $\mathrm{Ti}\left({ }^{\mathrm{Me}} \mathrm{PDP}\right)_{2}$ with $50 \%$ probability ellipsoids. Hydrogen atoms were omitted for clarity.

\section{$\left[\mathbf{L i}(\text { thf })_{4}\right]\left[\mathbf{T i}\left({ }^{\mathrm{Me}} \mathbf{P D P}\right)_{2}\right]:$}

Two of the four molecules of THF bound to the lithium cation suffer from a 50:50 two-site disorder. The two $\mathrm{C}-\mathrm{O}$ and three $\mathrm{C}-\mathrm{C}$ bond distances within each disordered site were restrained to $1.46 \pm 0.01 \AA$ and $1.54 \pm 0.01 \AA$, respectively. The $\mathrm{O}$ and four $\mathrm{C}$ atoms of each disordered site were refined using an isotropic thermal model. The disordered toluene that lies near the center of inversion was refined while fitting the six carbon atoms of the phenyl ring to a hexagon with an edge length of $1.39 \AA$. 

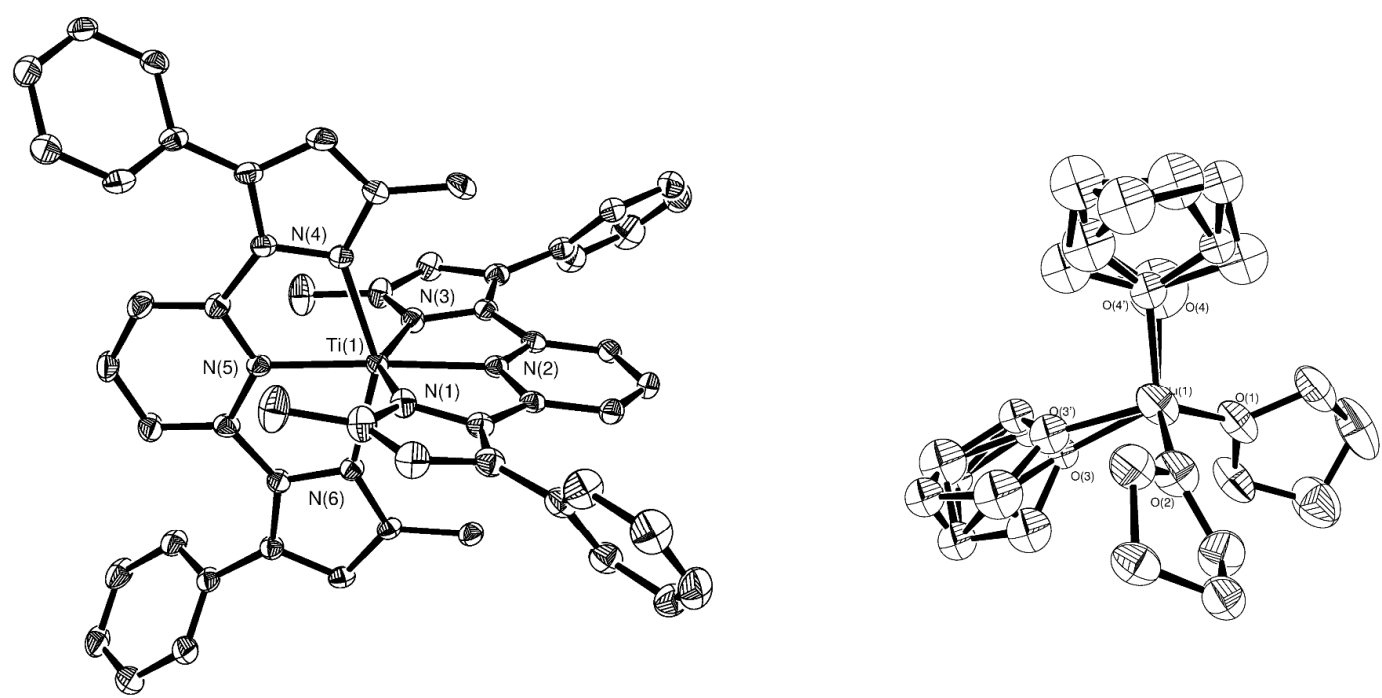

Figure S10. Representation of the molecular structure of $\left[\mathrm{Li}(\operatorname{thf})_{4}\right]\left[\mathrm{Ti}\left({ }^{\mathrm{Me}} \mathrm{PDP}\right)_{2}\right]$ with $50 \%$ probability ellipsoids. Hydrogen atoms were omitted for clarity. Left: Anion $\left[\mathrm{Ti}\left({ }^{\mathrm{Me}} \mathrm{PDP}\right)_{2}\right]^{1-}$. Right: Cation $\left[\mathrm{Li}(\mathrm{thf})_{4}\right]^{1+}$; two of the THF ligands were found to be disordered over two positions. The atom positions for these rings were modelled isotropically.

\section{$\operatorname{Zr}\left({ }^{\mathrm{Me}} \mathrm{PDP}\right)_{2}$ :}

One of the two molecules of $\mathrm{CH}_{2} \mathrm{Cl}_{2}$ in the asymmetric unit is badly disordered and was treated as a diffuse electron density contribution with the aid of the SQUEEZE routine in the program PLATON. ${ }^{9,10}$ A poorly resolved molecule of pentane was also treated as a diffuse electron density contribution with the aid of the SQUEEZE routine in the program PLATON. Although specific positions for the independent carbon, hydrogen, and chlorine atoms of the disordered $\mathrm{CH}_{2} \mathrm{Cl}_{2}$ molecule and the carbon and hydrogen atoms of the pentane molecule were not determined, the calculated density, absorption coefficient, and empirical formula weight reflect their presence within the crystal lattice. Consequently, the empirical formula and empirical formula weight calculated by the CHECKcif program based up one molecule of $\left[\mathrm{C}_{27} \mathrm{H}_{21} \mathrm{~N}_{3}\right]_{2} \mathrm{Zr}$ and one resolved molecule of $\mathrm{CH}_{2} \mathrm{Cl}_{2}$ are $\mathrm{C}_{55} \mathrm{H}_{44} \mathrm{Cl}_{2} \mathrm{~N}_{6} \mathrm{Zr}$ and 951.08, respectively, whereas the reported empirical formula weight based on one molecule of $\left[\mathrm{C}_{27} \mathrm{H}_{21} \mathrm{~N}_{3}\right]_{2} \mathrm{Zr}$, two molecules of $\mathrm{CH}_{2} \mathrm{Cl}_{2}$, and one molecule of pentane located on a center of symmetry are $\mathrm{C}_{58.50} \mathrm{H}_{52} \mathrm{Cl}_{4} \mathrm{~N}_{6} \mathrm{Zr}$ and 1072.08 , respectively. The greater than $10 \%$ discrepancy between the calculated molecular weight (based on the refined atoms in the crystallographic asymmetric unit) and the reported molecular weight that includes the $\mathrm{CH}_{2} \mathrm{Cl}_{2}$ and pentane 
molecules treated by SQUEEZE produces a Level A alert when CHECKcif is run on the corresponding cif file. The $\mathrm{C}-\mathrm{Cl}$ distances within the resolved $\mathrm{CH}_{2} \mathrm{Cl}_{2}$ molecule were restrained at $1.72 \pm 0.01 \mathrm{~A}$.

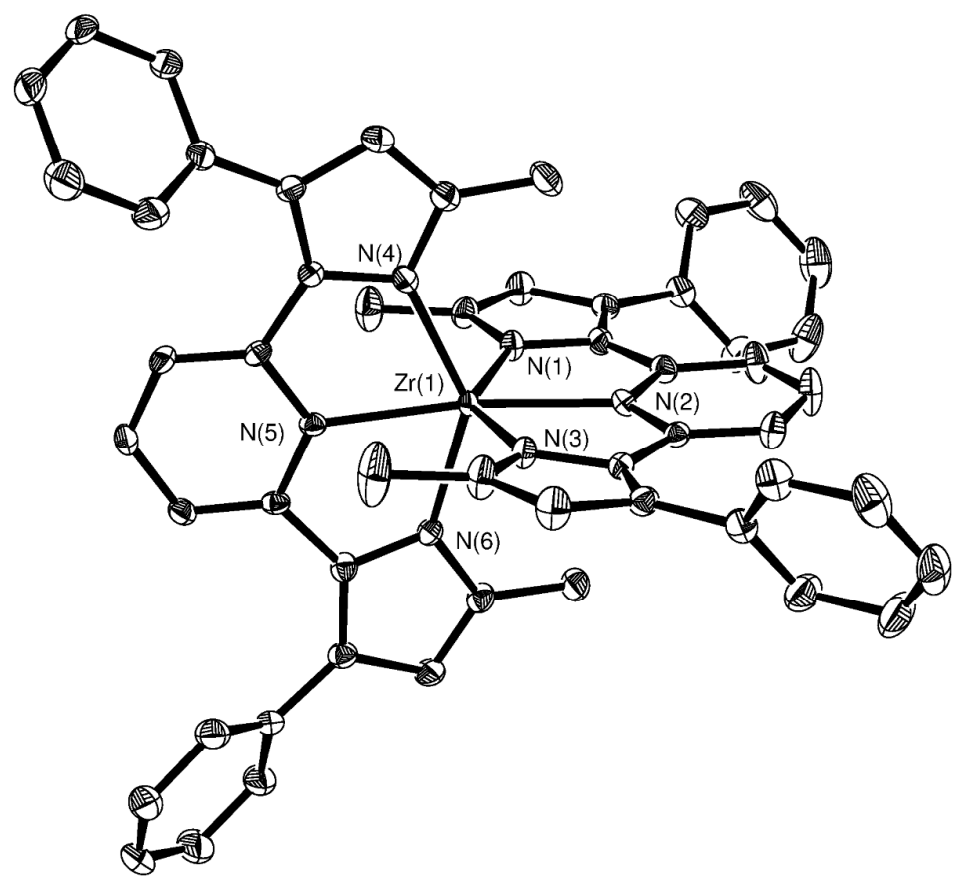

Figure S11. Representation of the molecular structure of $\mathrm{Zr}\left({ }^{\mathrm{Me}} \mathrm{PDP}\right)_{2}$ with $50 \%$ probability ellipsoids. Hydrogen atoms were omitted for clarity. 
Table S1. Selected bond distances $(\AA)$.

\begin{tabular}{|c|c|c|c|}
\hline & $\left({ }^{\mathrm{Me}} \mathrm{PDP}\right)_{2} \mathrm{Zr}$ & $\left({ }^{\mathrm{Me}} \mathrm{PDP}\right)_{2} \mathrm{Ti}$ & {$\left[\left({ }^{\mathrm{Me}} \mathrm{PDP}\right)_{2} \mathrm{Ti}\right]^{-}$} \\
\hline M1-N1 & $2.150(2)$ & $2.058(3)$ & $2.115(2)$ \\
\hline M1-N2 & $2.289(2)$ & $2.122(3)$ & $2.127(2)$ \\
\hline M1-N3 & $2.184(2)$ & $2.020(3)$ & $2.110(2)$ \\
\hline M1-N4 & $2.144(3)$ & $2.058(3)$ & $2.119(2)$ \\
\hline M1-N5 & $2.300(2)$ & $2.122(3)$ & $2.131(2)$ \\
\hline M1-N6 & $2.172(2)$ & $2.020(3)$ & $2.107(2)$ \\
\hline \multicolumn{4}{|l|}{ Pyrrole (I) } \\
\hline N1-C1 & $1.380(4)$ & $1.384(4)$ & $1.361(4)$ \\
\hline $\mathrm{C} 1-\mathrm{C} 2$ & $1.370(5)$ & $1.374(5)$ & $1.381(4)$ \\
\hline $\mathrm{C} 2-\mathrm{C} 3$ & $1.426(5)$ & $1.414(5)$ & $1.409(4)$ \\
\hline $\mathrm{C} 3-\mathrm{C} 4$ & $1.385(4)$ & $1.388(5)$ & $1.397(4)$ \\
\hline N1-C4 & $1.398(4)$ & $1.393(4)$ & $1.386(4)$ \\
\hline $\mathrm{C} 4-\mathrm{C} 5$ & $1.443(4)$ & $1.439(5)$ & $1.451(4)$ \\
\hline \multicolumn{4}{|l|}{ Pyridine (I) } \\
\hline $\mathrm{N} 2-\mathrm{C} 5$ & $1.365(4)$ & $1.371(4)$ & $1.360(3)$ \\
\hline $\mathrm{C} 5-\mathrm{C} 6$ & $1.386(4)$ & $1.390(5)$ & $1.391(4)$ \\
\hline $\mathrm{C} 6-\mathrm{C} 7$ & $1.377(5)$ & $1.380(5)$ & $1.383(4)$ \\
\hline $\mathrm{C} 7-\mathrm{C} 8$ & $1.382(5)$ & $1.379(5)$ & $1.383(4)$ \\
\hline $\mathrm{C} 8-\mathrm{C} 9$ & $1.383(4)$ & $1.407(5)$ & $1.393(4)$ \\
\hline $\mathrm{N} 2-\mathrm{C} 9$ & $1.363(4)$ & $1.365(4)$ & $1.361(3)$ \\
\hline C9-C10 & $1.447(4)$ & $1.436(5)$ & $1.455(4)$ \\
\hline \multicolumn{4}{|l|}{ Pyrrole (II) } \\
\hline N3-C10 & $1.388(4)$ & $1.385(4)$ & $1.380(3)$ \\
\hline $\mathrm{C} 10-\mathrm{C} 11$ & $1.392(4)$ & $1.383(5)$ & $1.399(4)$ \\
\hline $\mathrm{C} 11-\mathrm{C} 12$ & $1.404(5)$ & $1.415(5)$ & $1.413(4)$ \\
\hline C12-C13 & $1.374(4)$ & $1.372(5)$ & $1.375(4)$ \\
\hline N3-C13 & $1.377(4)$ & $1.389(4)$ & $1.363(4)$ \\
\hline \multicolumn{4}{|l|}{ Pyrrole (III) } \\
\hline N4-C28 & $1.383(3)$ & & $1.357(3)$ \\
\hline $\mathrm{C} 28-\mathrm{C} 29$ & $1.372(5)$ & & $1.379(4)$ \\
\hline C29-C30 & $1.418(4)$ & & $1.408(4)$ \\
\hline
\end{tabular}




\begin{tabular}{|c|c|c|}
\hline C30-C31 & $1.386(4)$ & $1.402(4)$ \\
\hline N4-C31 & $1.392(4)$ & $1.382(3)$ \\
\hline C31-C32 & $1.448(4)$ & $1.446(4)$ \\
\hline \multicolumn{3}{|l|}{ Pyridine (II) } \\
\hline N5-C32 & $1.360(4)$ & $1.360(3)$ \\
\hline C32-C33 & $1.384(4)$ & $1.392(4)$ \\
\hline C33-C34 & $1.380(4)$ & $1.387(4)$ \\
\hline C34-C35 & $1.384(5)$ & $1.388(4)$ \\
\hline C35-C36 & $1.387(4)$ & $1.396(4)$ \\
\hline N5-C36 & $1.360(3)$ & $1.362(3)$ \\
\hline C36-C37 & $1.447(4)$ & $1.438(4)$ \\
\hline \multicolumn{3}{|l|}{ Pyrrole (IV) } \\
\hline N6-C37 & $1.390(4)$ & $1.388(3)$ \\
\hline C37-C38 & $1.386(4)$ & $1.399(4)$ \\
\hline C38-C39 & $1.418(5)$ & $1.405(4)$ \\
\hline C39-C40 & $1.376(4)$ & $1.381(4)$ \\
\hline N6-C40 & $1.375(4)$ & $1.364(3)$ \\
\hline
\end{tabular}

\section{Photoluminescent Properties of $\mathrm{Zr}\left({ }^{\mathrm{Me}} \mathrm{PDP}\right)_{2}$}

\subsection{Quantum Yield Determination}

The quantum yield of $\mathrm{Zr}\left({ }^{\mathrm{Me}} \mathrm{PDP}\right)_{2}$ was determined via comparative method. ${ }^{11,12}$ Rhodamine 6G in ethanol $(\Phi=0.94)$ was used as a standard and the excitation wavelength for all photoluminescence intensity measurements was kept constant at $488 \mathrm{~nm} .{ }^{13}$ The quantum yield was calculated by using the following equation:

$$
\Phi_{X}=\Phi_{S T}\left(\frac{\operatorname{Grad}_{X}}{\operatorname{Grad}_{S T}}\right)\left(\frac{n_{X}^{2}}{n_{S T}^{2}}\right)
$$

The subscripts $X$ and $S T$ stand for the sample and the standard, respectively. $\Phi$ is the photoluminescence quantum yield. Grad is the gradient from the plot of integrated photoluminescence intensity versus absorbance, and $n$ is the refractive index of the solvent. 


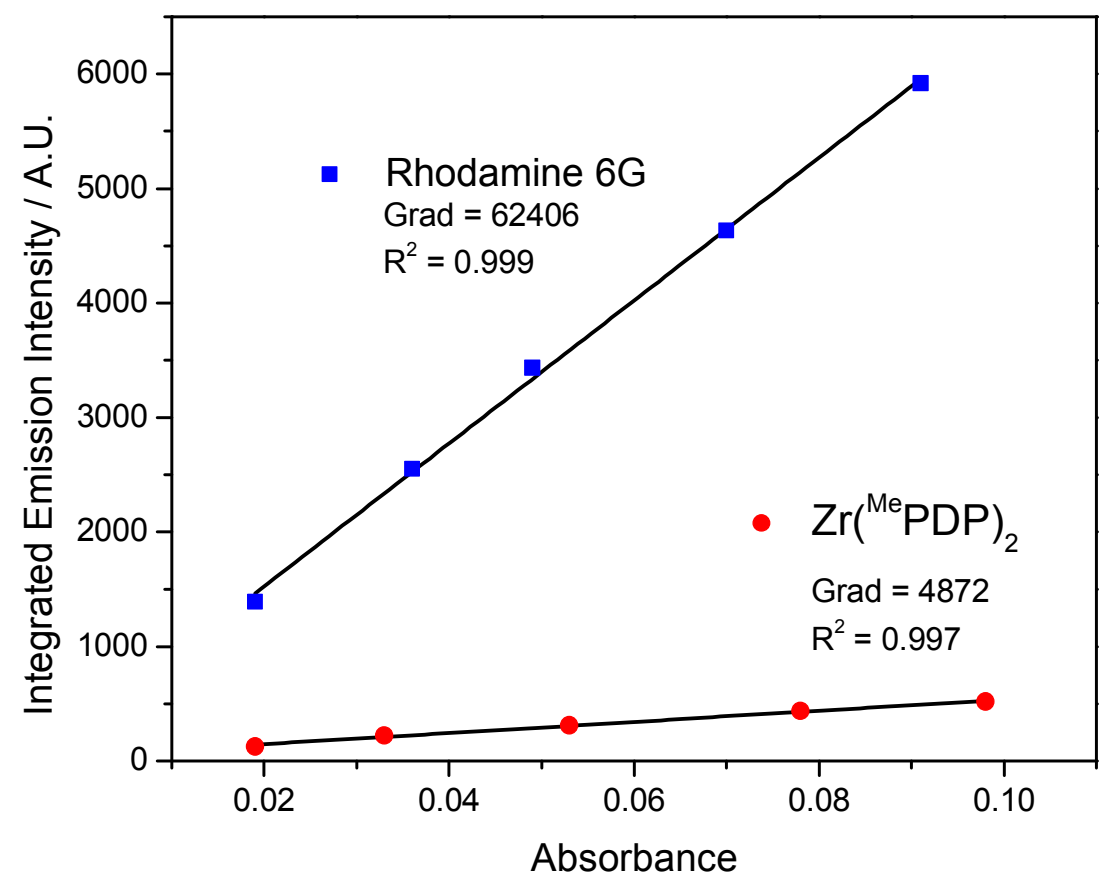

Figure S12. Plot of absorbance at $488 \mathrm{~nm}$ versus integration of the emission spectrum for Rhodamine $6 \mathrm{G}$ in ethanol $(\Phi=0.94)$ and $\mathrm{Zr}\left({ }^{\mathrm{Me}} \mathrm{PDP}\right)_{2}$ in THF. The black lines represent linear fits of the data and the gradients used for the quantum yield determination is shown next to the corresponding fit.

\subsection{Quenching Experiments}

Samples for Stern-Volmer quenching experiments with ${ }^{\mathrm{R}} \mathrm{BIH}(\mathrm{R}=\mathrm{Me}, \mathrm{H}, \mathrm{Cl})$ were prepared individually in the drybox from stock solutions of $\mathrm{Zr}\left({ }^{\mathrm{Me}} \mathrm{PDP}\right)_{2}$ and the corresponding ${ }^{\mathrm{R}} \mathrm{BIH}$ derivative in THF. The final concentration of $\mathrm{Zr}\left({ }^{\mathrm{Me}} \mathrm{PDP}\right)_{2}$ for each measurement was $3.83 \cdot 10^{-6} \mathrm{~mol} \mathrm{~L}^{-1}$ leading to a maximum absorbance in the visible region of the absorption spectrum below 0.1 to avoid effects from self-absorption. An electronic absorption spectrum was recorded for each sample after the luminescence measurement to confirm the integrity of the sample. Emission intensities were obtained via numerical integration of the experimental spectra (Figure S13, Figure S15) and Stern-Volmer plots (Figure S14, Figure S16) were generated using the absolute concentration of the quencher for the corresponding sample. 


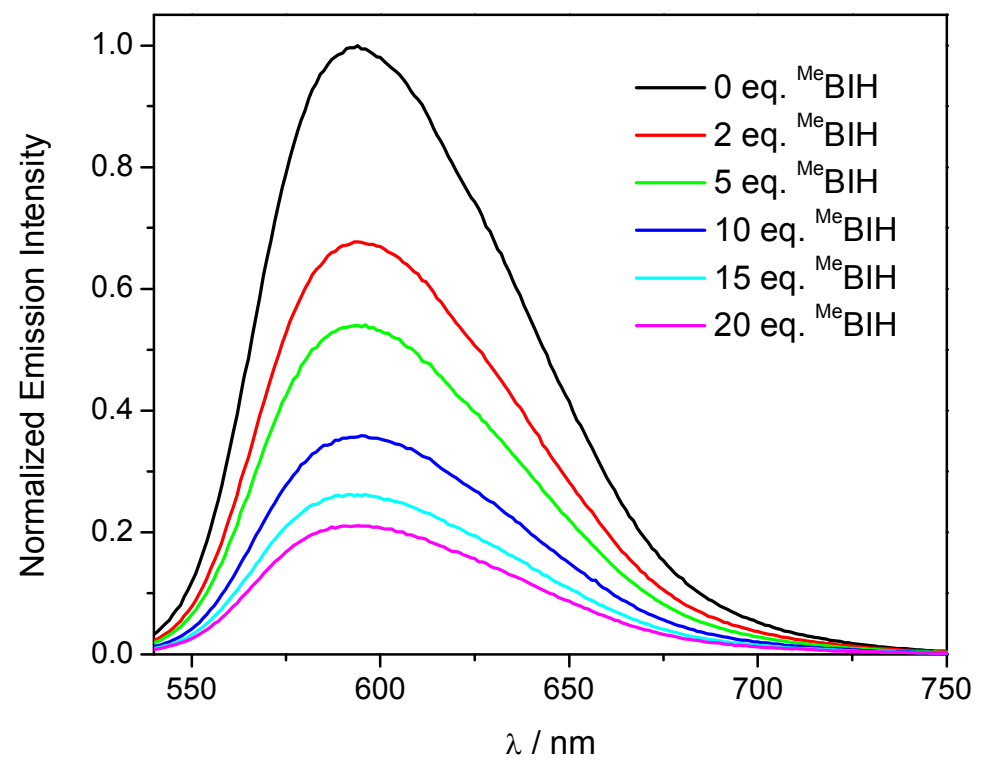

Figure S13. Emission spectra of $\mathrm{Zr}\left({ }^{\mathrm{Me}} \mathrm{PDP}\right)_{2}$ upon excitation at $527 \mathrm{~nm}$ in THF solution in the presence of varying amounts of ${ }^{\mathrm{Me}} \mathrm{BIH}$.

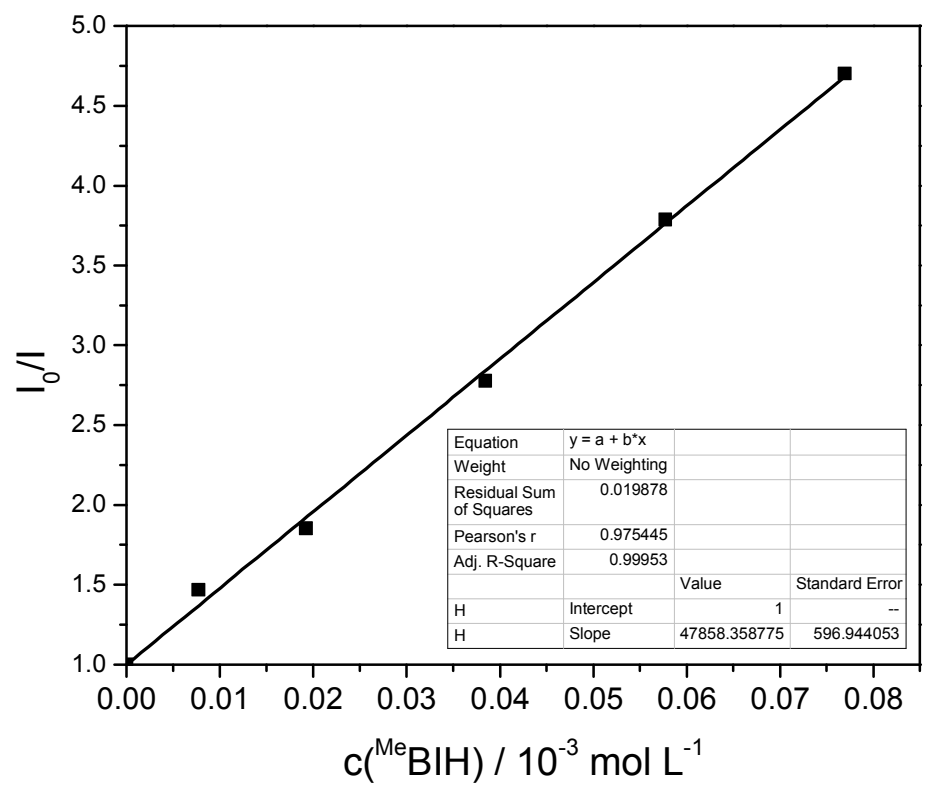

Figure S14. Stern-Volmer quenching of $\mathrm{Zr}\left({ }^{\mathrm{Me}} \mathrm{PDP}\right)_{2}$ by ${ }^{\mathrm{Me}} \mathrm{BIH}$ in anhydrous THF under inert atmosphere. 


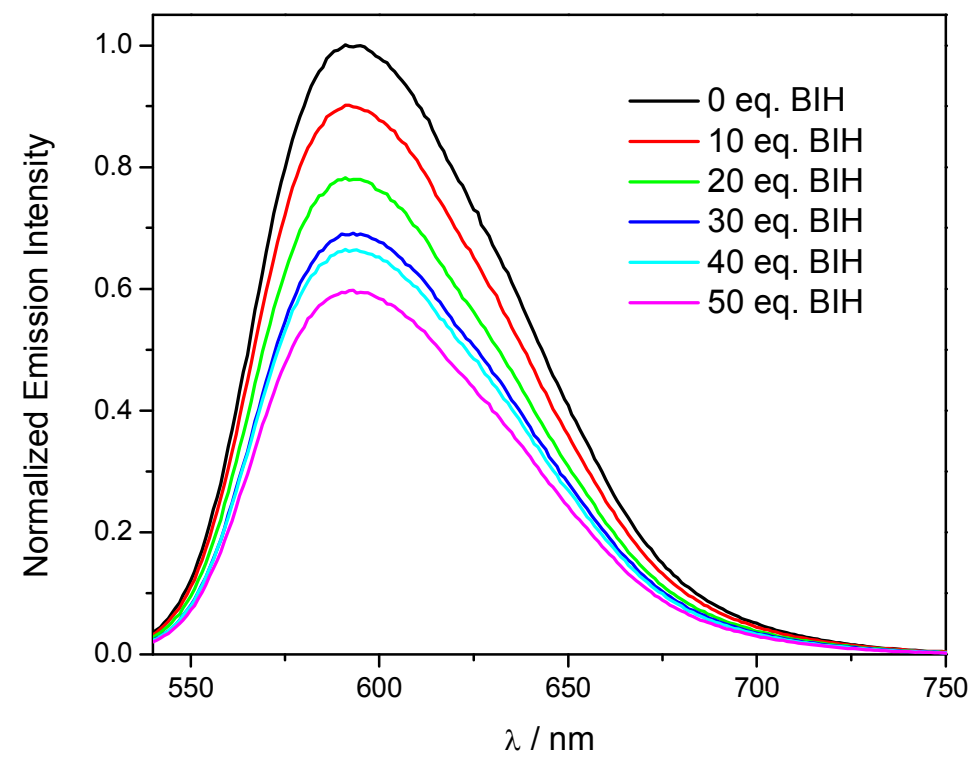

Figure S15. Emission spectra of $\mathrm{Zr}\left({ }^{\mathrm{Me}} \mathrm{PDP}\right)_{2}$ upon excitation at $527 \mathrm{~nm}$ in THF solution in the presence of varying amounts of BIH.

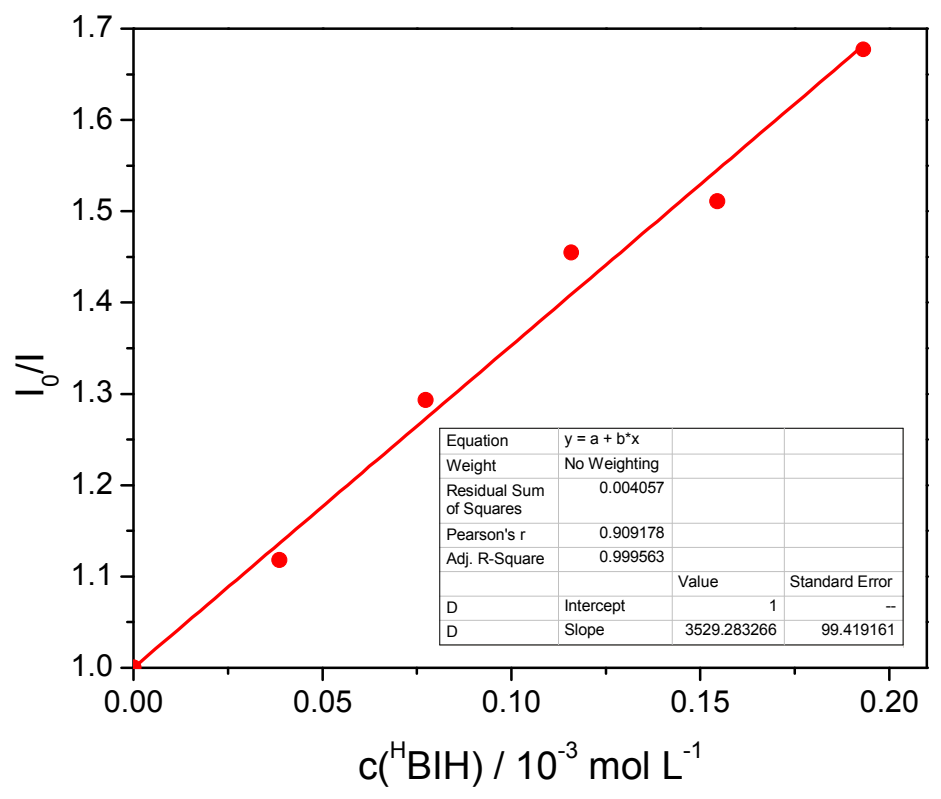

Figure S16. Stern-Volmer quenching of $\mathrm{Zr}\left({ }^{\mathrm{Me}} \mathrm{PDP}\right)_{2}$ by $\mathrm{BIH}$ in anhydrous THF under inert atmosphere. 


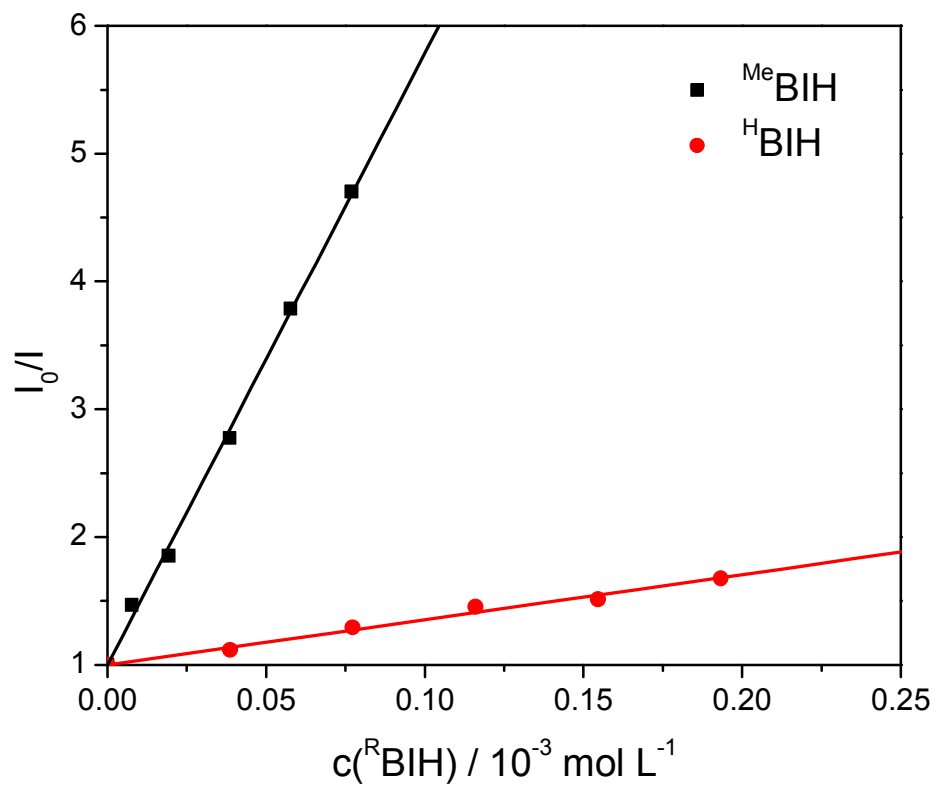

Figure S17. Comparison of Stern-Volmer quenching data of $\mathrm{Zr}\left({ }^{\mathrm{Me}} \mathrm{PDP}\right)_{2}$ with ${ }^{\mathrm{R}} \mathrm{BIH}$ in $\mathrm{THF}$ under inert atmosphere.

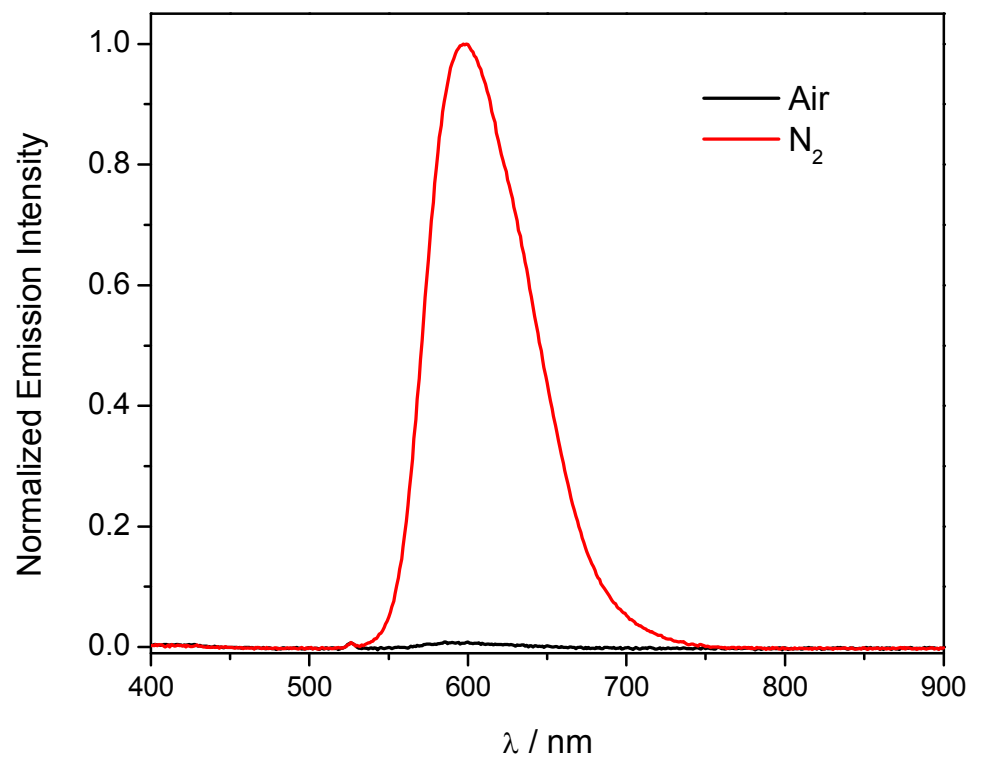

Figure S18. Emission spectra of $\mathrm{Zr}\left({ }^{\mathrm{Me}} \mathrm{PDP}\right)_{2}$ upon excitation at $527 \mathrm{~nm}$ in THF under inert atmosphere (red) and upon exposure to air (black). 


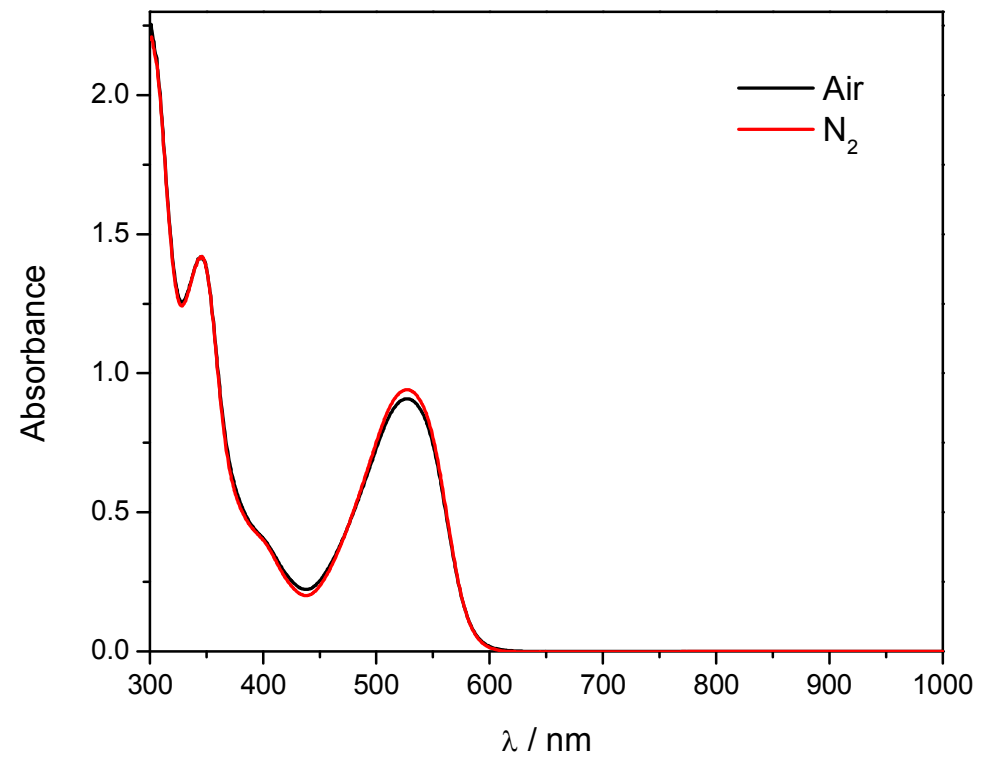

Figure S19. Electronic absorption spectra of $\mathrm{Zr}\left({ }^{\mathrm{Me}} \mathrm{PDP}\right)_{2}$ in THF under inert atmosphere (red) and upon exposure to air (black). 


\section{Cyclic Voltammetry Data}

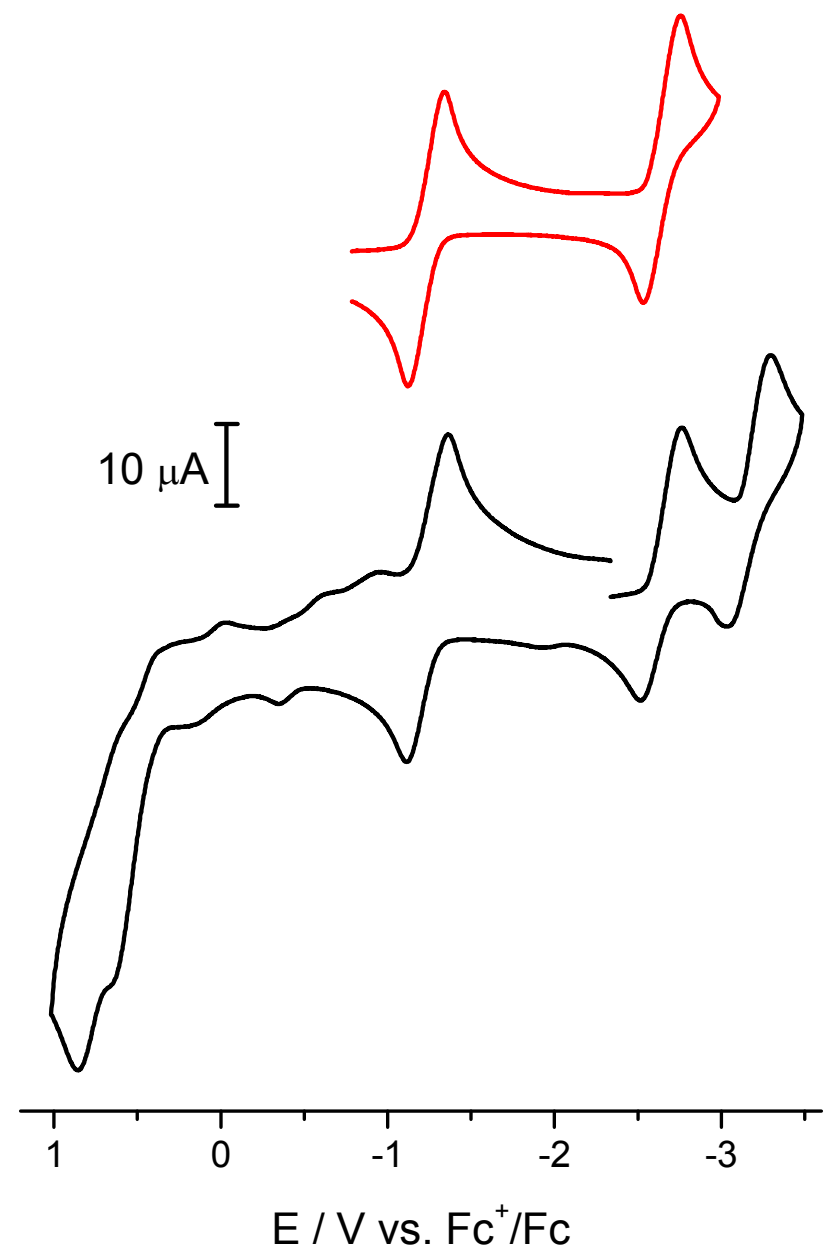

Figure S20. Cyclic voltammogram of $\mathrm{Ti}\left({ }^{\mathrm{Me}} \mathrm{PDP}\right)_{2}$ in $\mathrm{THF}$ at room temperature (scan rate 200 $\mathrm{mV} \mathrm{s}^{-1}, 0.1 \mathrm{M}\left[\mathrm{N}(n-\mathrm{Bu})_{4}\right] \mathrm{PF}_{6}$, glassy carbon working electrode). Black: Overview of all redox events. Red: Fully reversible redox events. 


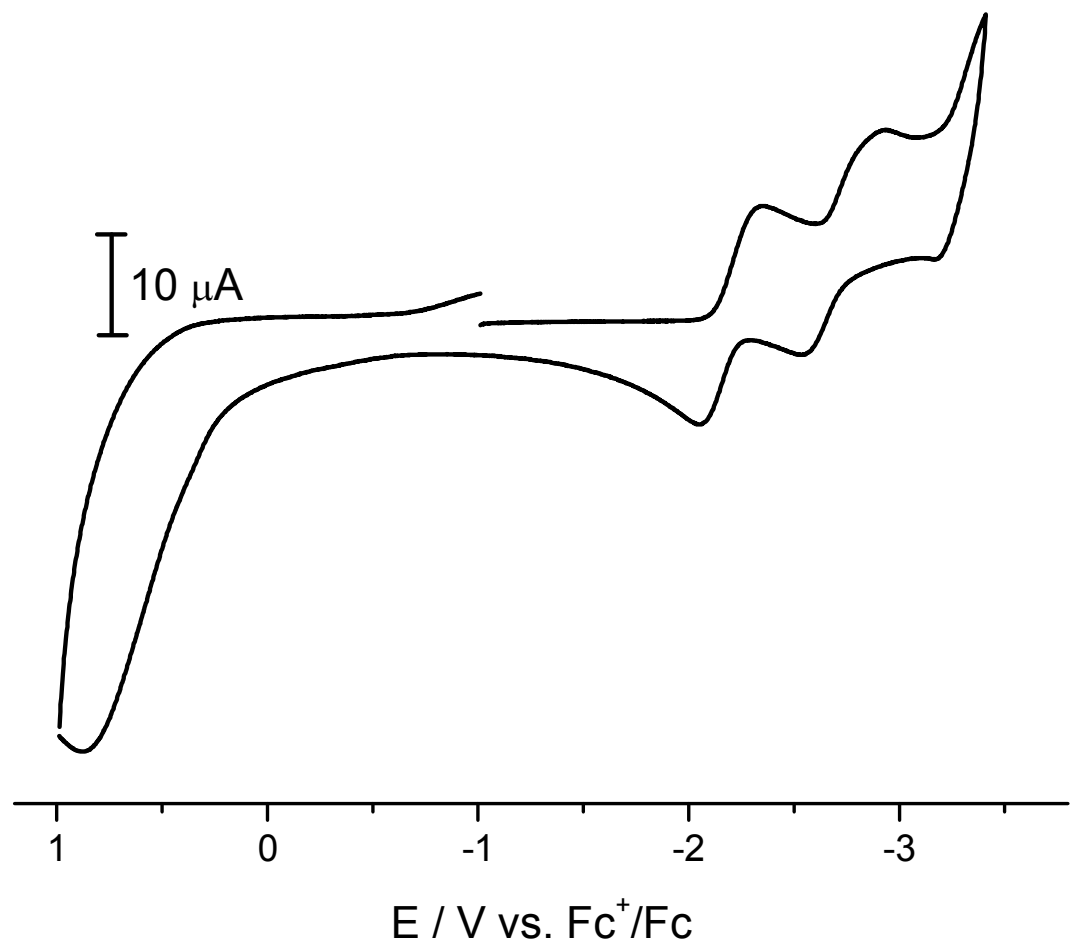

Figure S21. Cyclic voltammogram of $\mathrm{Zr}\left({ }^{\mathrm{Me}} \mathrm{PDP}\right)_{2}$ in THF at room temperature (scan rate 200 $\mathrm{mV} \mathrm{s}^{-1}, 0.1 \mathrm{M}\left[\mathrm{N}(n-\mathrm{Bu})_{4}\right] \mathrm{PF}_{6}$, glassy carbon working electrode).

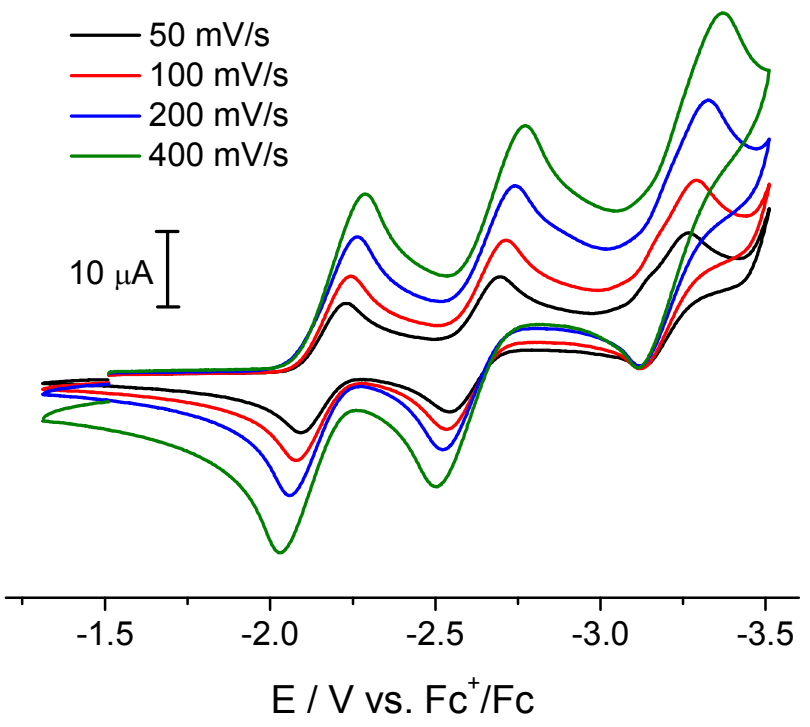

Figure S22. Cyclic voltammogram of $\mathrm{Zr}\left({ }^{\mathrm{Me}} \mathrm{PDP}\right)_{2}$ in $\mathrm{THF}$ at room temperature at different scan rates (o.1 M $\left[\mathrm{N}(n-\mathrm{Bu})_{4}\right] \mathrm{PF}_{6}$, glassy carbon working electrode). 


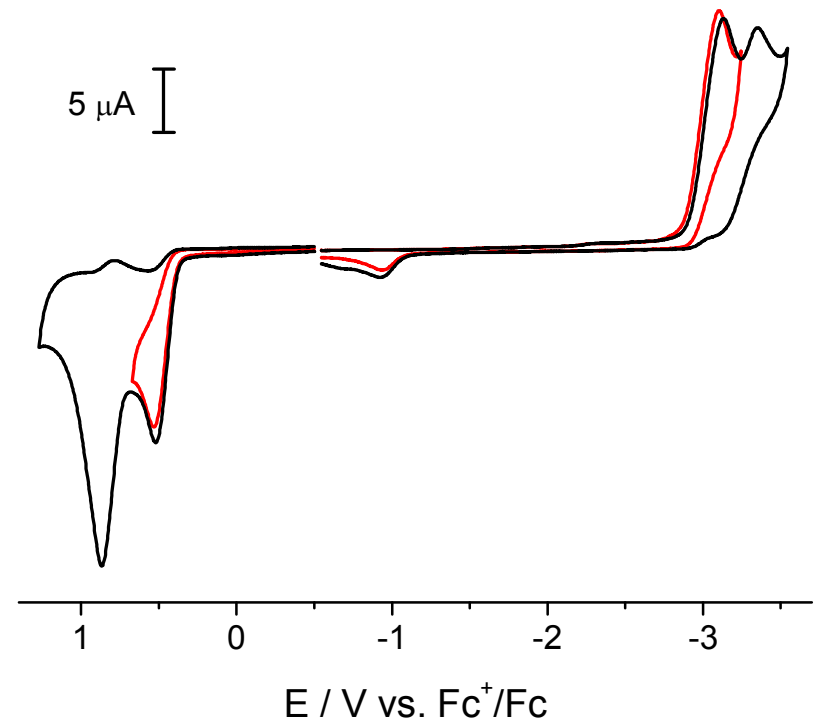

Figure S23. Cyclic voltammogram of $\mathrm{H}_{2}{ }^{\mathrm{Me}} \mathrm{PDP}$ in THF at room temperature (scan rate $50 \mathrm{mV} \mathrm{s}^{-1}, 0.1 \mathrm{M}\left[\mathrm{N}(n-\mathrm{Bu})_{4}\right] \mathrm{PF}_{6}$, glassy carbon working electrode). Two irreversible oxidations are observed at $\mathrm{E}_{\mathrm{pa}}=0.52$ and $0.87 \mathrm{~V}$, while two irreversible reduction events can be identified at $\mathrm{E}_{\mathrm{pc}}=-3.13$ and $-3.35 \mathrm{~V}$. 


\section{Photoredox Catalysis}

\subsection{Experimental Setup for Photoredox Reactions}

All photoredox experiments were performed using commercially available LED light strips with an emission maximum at $520 \mathrm{~nm}$. Constant room temperature conditions were maintained using a waterbath in a jacketed glass beaker with water cooling.
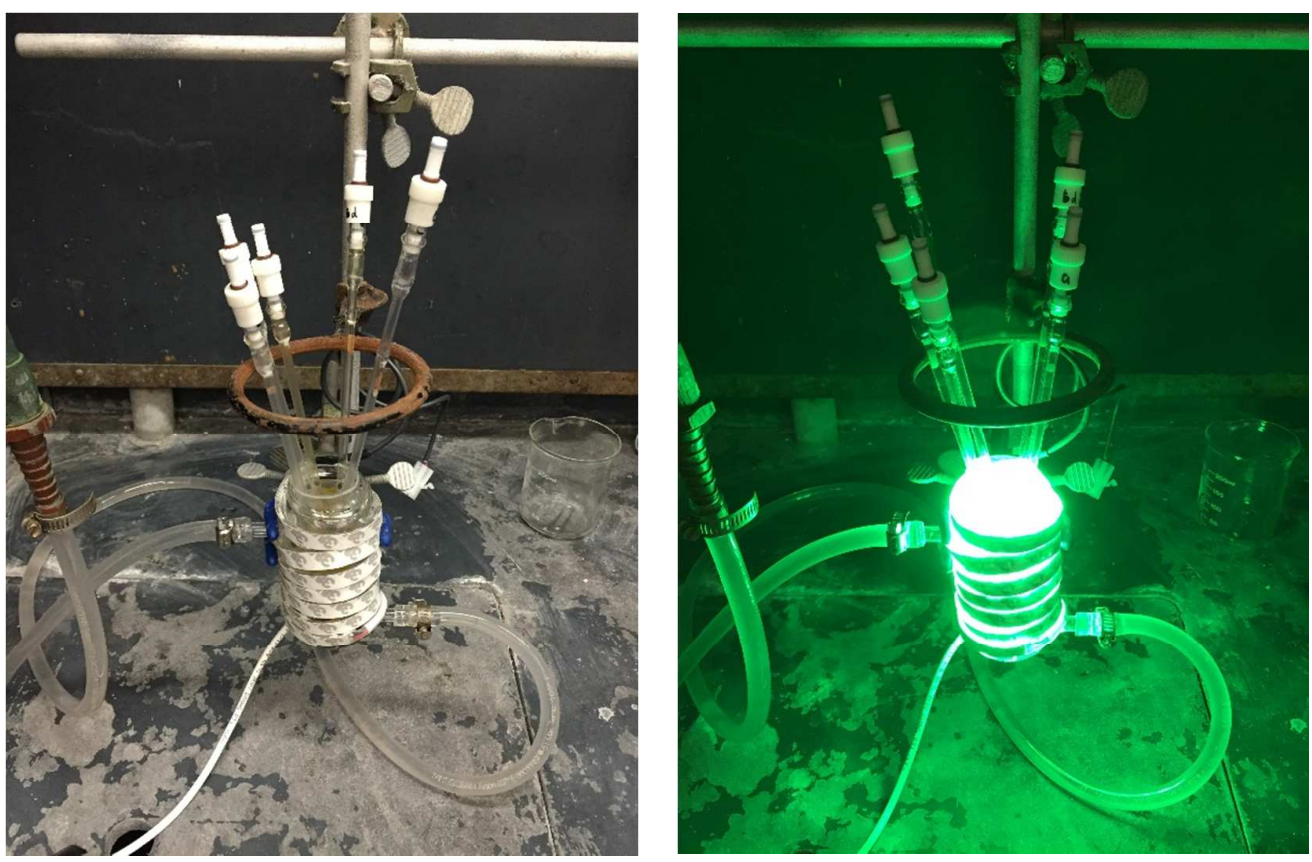

Figure S24. Experimental setup for irradiation of NMR tubes.

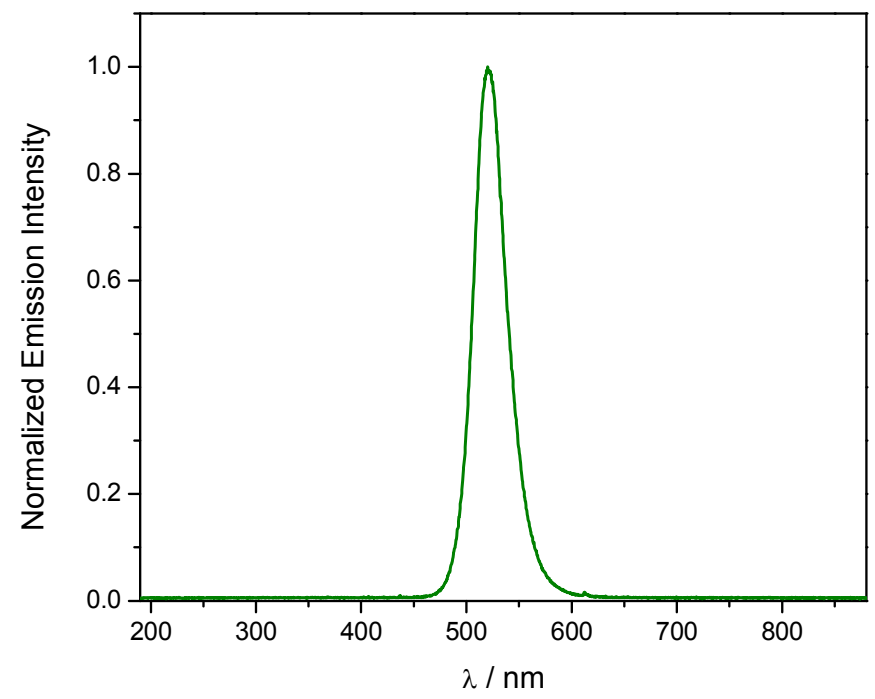

Figure S25. Emission profile of LED light strips used for photoredox reactions. 


\subsection{Photoredox-Catalyzed Debromination of Ethyl Bromodifluoroacetate.}

In the drybox, a J. Young NMR tube was charged with $\left({ }^{\mathrm{Me}} \mathrm{PDP}\right)_{2} \mathrm{Zr}(1 \mathrm{mg}, 0.001 \mathrm{mmol}, 0.02$ equiv), ${ }^{\mathrm{Me}} \mathrm{BIH}$ (14 mg, $0.059 \mathrm{mmol}, 1.00$ equiv), and ethyl bromodifluoroacetate (12 mg, 0.059 mmol, 1.00 equiv). $0.6 \mathrm{~mL}$ of $\mathrm{C}_{6} \mathrm{D}_{6}$ was added. 1,3,5-trimethoxybenzene was added as an internal standard. The mixture was placed in a jacketed glass beaker with water cooling and irradiated with green LED light $\left(\lambda_{\max }=520 \mathrm{~nm}\right)$. The reaction was complete (as judged by NMR analysis) after 2.5 hours. The products were analyzed by NMR spectroscopy and the yields are based on internal standard.

Table S2. Conditions and control experiments for the debromination of ethyl bromodifluoroacetate using photoredox catalysis.

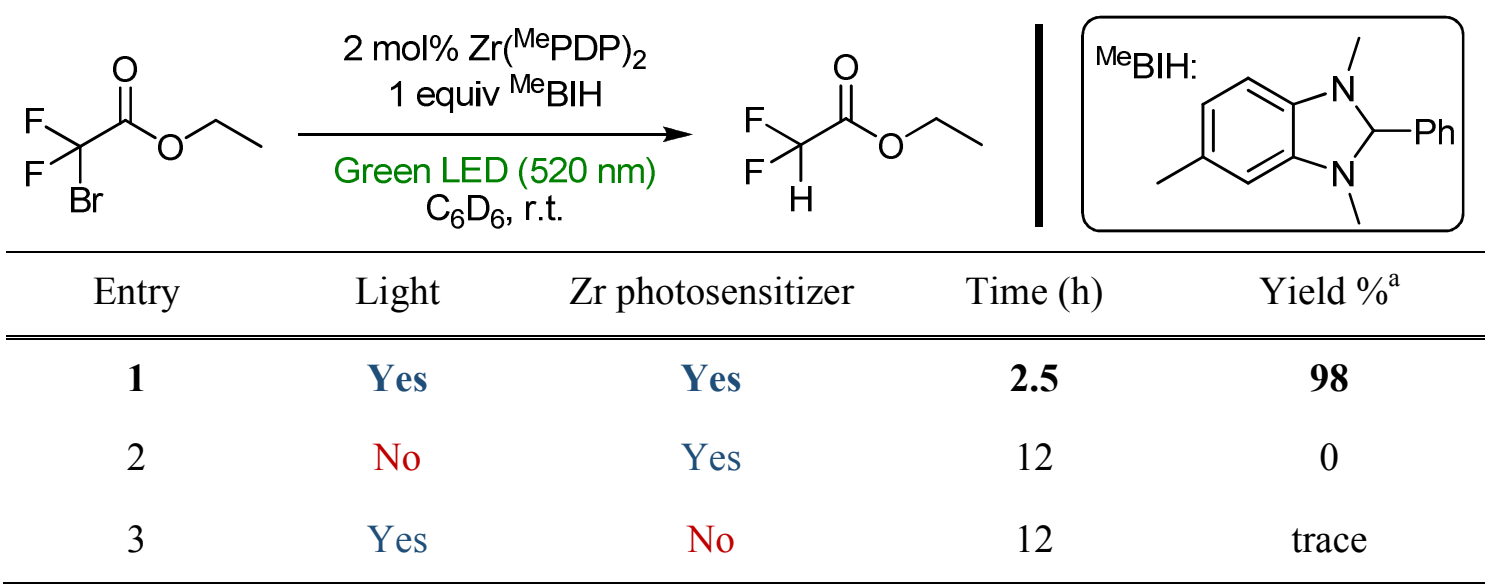

${ }^{\text {a }}$ H NMR yield using 1,3,5-trimethoxybenzene as the internal standard. 

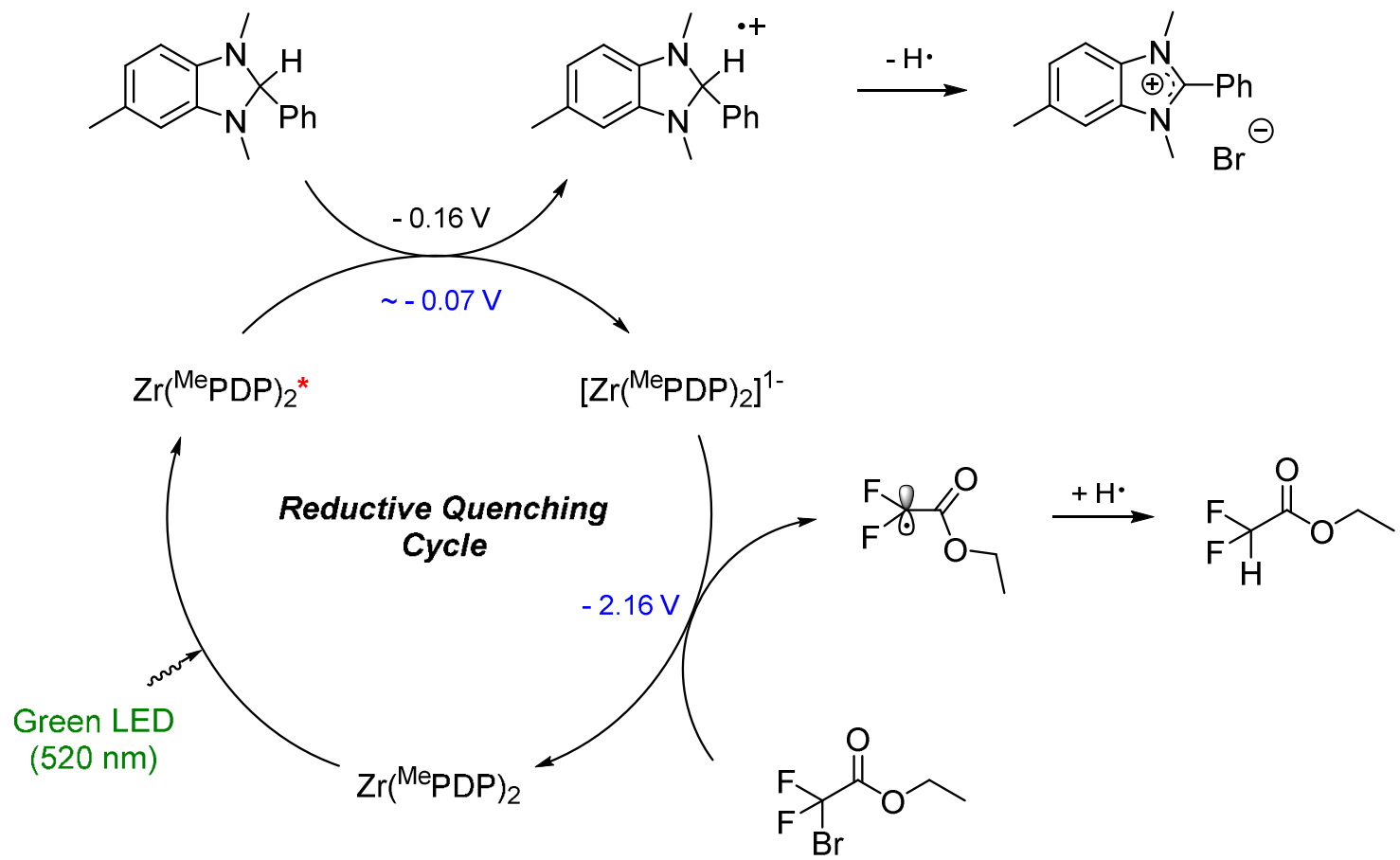

Figure S26. Proposed mechanism for the photoredox-catalyzed debromination of ethyl bromodifluoroacetate. All potentials are given versus $\mathrm{Fc}^{+} / \mathrm{Fc}$. 


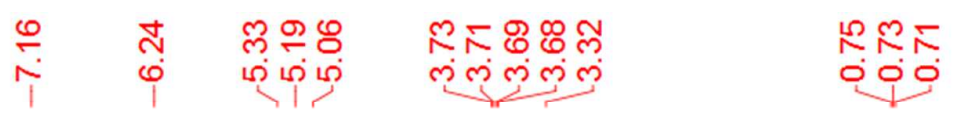

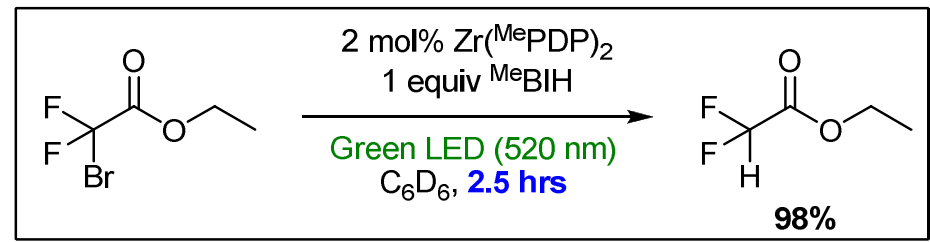

1,3,5-trimethoxybenzene

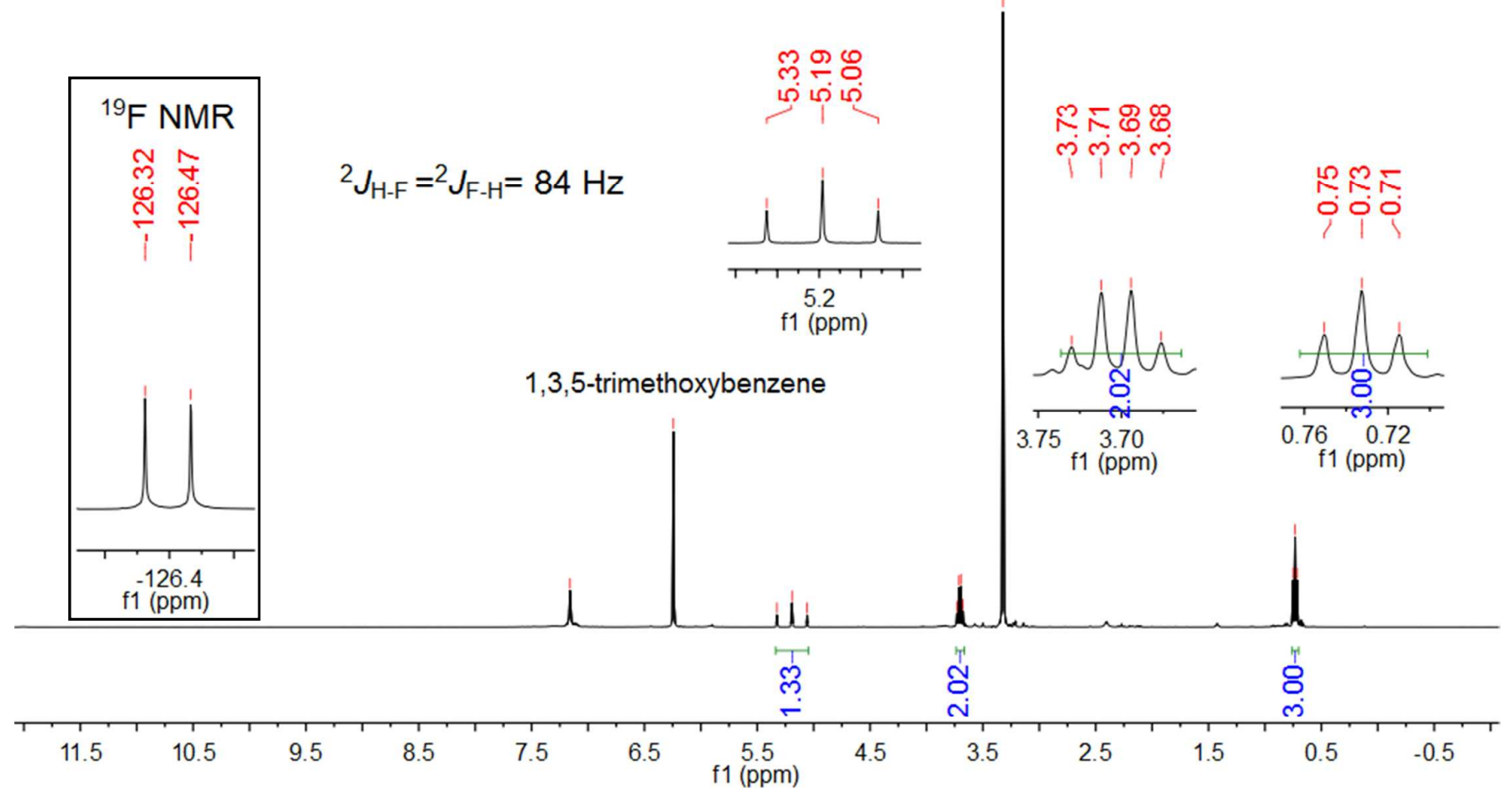

Figure S27. ${ }^{1} \mathrm{H}$ NMR spectrum of a mixture of ethyl bromodifluoroacetate and ${ }^{\mathrm{Me}} \mathrm{BIH}$ in the presence of $\mathrm{Zr}\left({ }^{\mathrm{Me}} \mathrm{PDP}\right)_{2}$ after irradiation. 


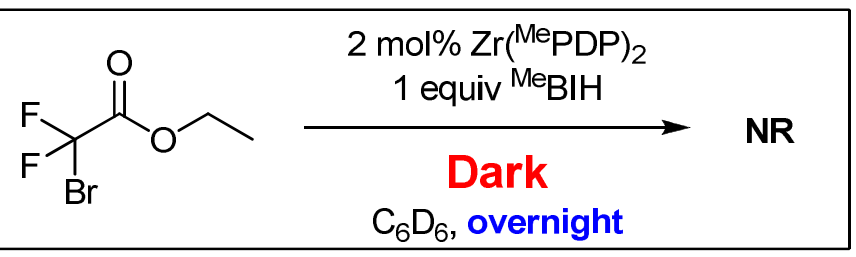

$\square \quad{ }^{\mathrm{Me}} \mathrm{BIH}$

ethyl bromodifluoroacetate

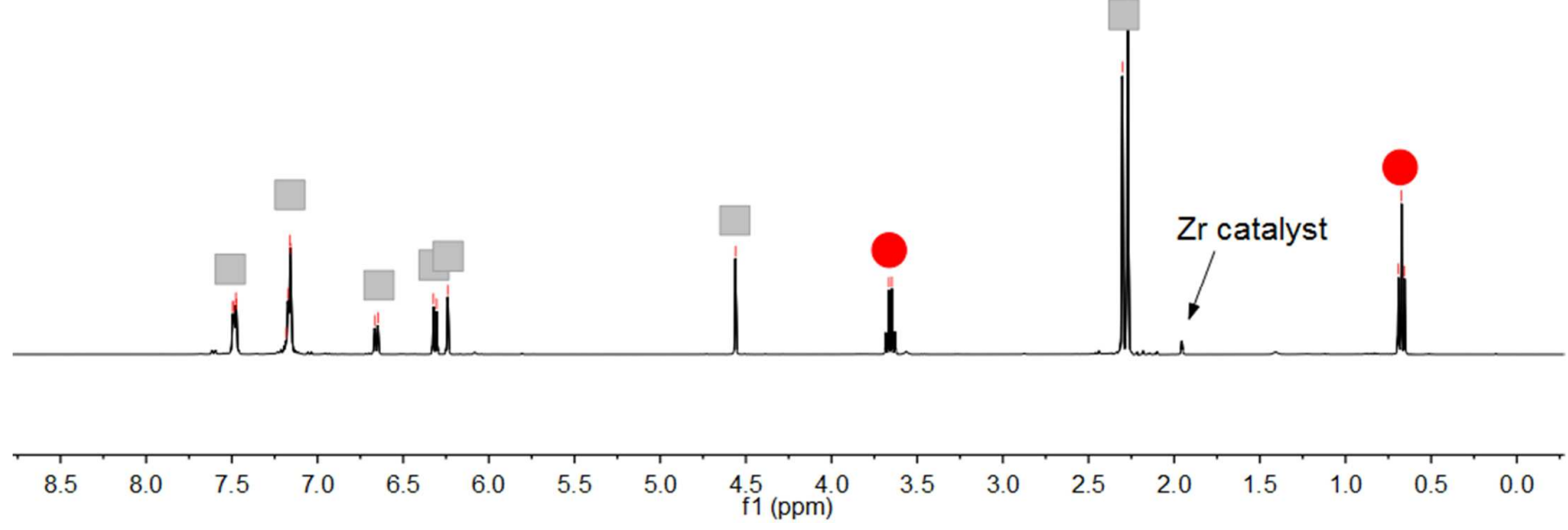

Figure S28. ${ }^{1} \mathrm{H}$ NMR spectrum of a mixture of ethyl bromodifluoroacetate and ${ }^{\mathrm{Me}} \mathrm{BIH}$ in the presence of $\mathrm{Zr}\left({ }^{\mathrm{Me}} \mathrm{PDP}\right)_{2}$ without irradiation. 


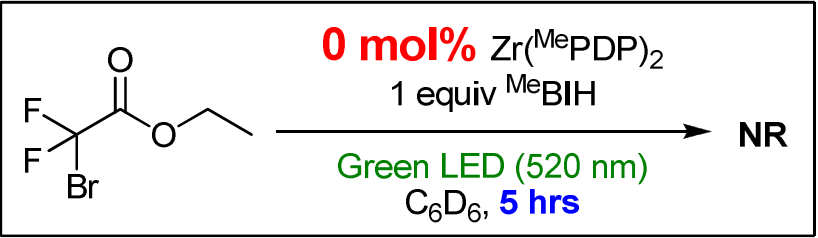

[ ${ }^{\mathrm{Me}} \mathrm{BIH}$

ethyl bromodifluoroacetate

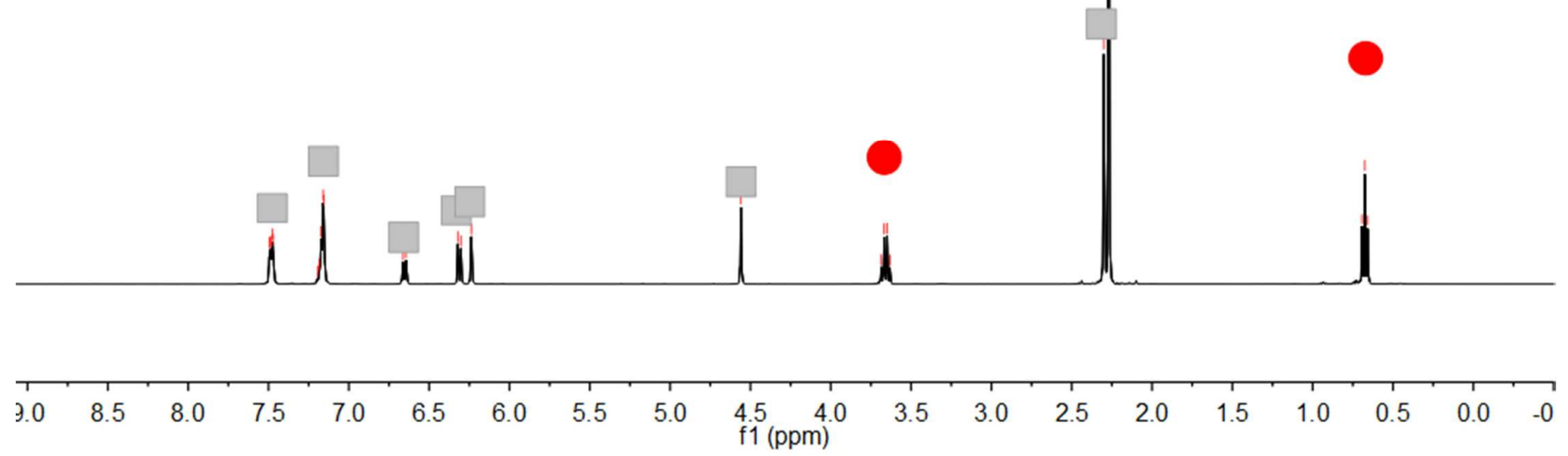

Figure S29. ${ }^{1} \mathrm{H}$ NMR spectrum of a mixture of ethyl bromodifluoroacetate and ${ }^{\mathrm{Me}} \mathrm{BIH}$ after irradiation for $5 \mathrm{~h}$. 


\subsection{Reduction of Diethyl Maleate using Photoredox Catalysis}

In the drybox, a J. Young NMR tube was charged with $\left({ }^{\mathrm{Me}} \mathrm{PDP}\right)_{2} \mathrm{Zr}(1 \mathrm{mg}, 0.001 \mathrm{mmol}, 0.02$ equiv), ${ }^{\mathrm{Me}} \mathrm{BIH}$ (see Table S3 for amounts), and diethyl maleate (4.1 mg, $0.024 \mathrm{mmol}, 1.00$ equiv). $0.6 \mathrm{~mL}$ of $\mathrm{C}_{6} \mathrm{D}_{6}$ was added. The mixture was placed in a water cooled glass vessel and irradiated with green LED light $\left(\lambda_{\max }=520 \mathrm{~nm}\right)$. Complete conversion of diethyl maleate was observed after 8 hours. The tube was opened to air and $\mathrm{H}_{2} \mathrm{O}(10 \mu \mathrm{L})$ was added to the reaction mixture. The biphasic system was shaken vigorously to ensure complete mixing of the organic and aqueous phases. A small amount of magnesium sulfate was added to absorb excess of water. 1,3,5-trimethoxybenzene was added as an internal standard. The products were analyzed by ${ }^{1} \mathrm{H}$ NMR spectroscopy and the yields are based on internal standard. The ${ }^{1} \mathrm{H}$ NMR spectroscopic data of diethyl maleate, diethyl fumarate, and diethyl succinate in $\mathrm{C}_{6} \mathrm{D}_{6}$ and $\mathrm{CDCl}_{3}$ were established from commercially available pure materials.

Table S3. Optimization of reaction conditions and control experiments for the reduction of diethyl maleate using photoredox catalysis.

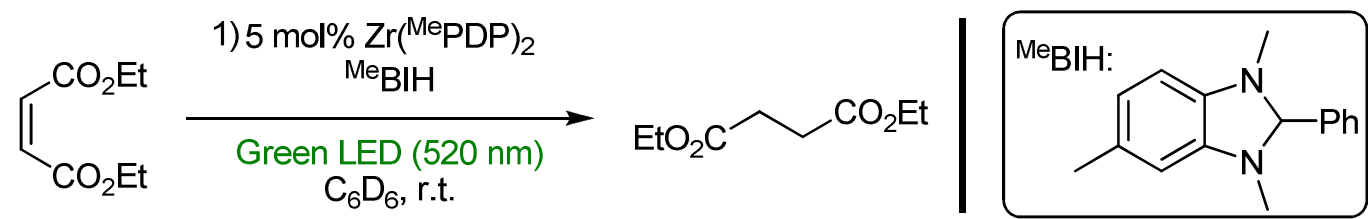

2) $\mathrm{H}_{2} \mathrm{O}$

\begin{tabular}{cccccc}
\hline Entry & Light & Zr photosensitizer & ${ }^{\mathrm{Me}}$ BIH (equiv) & Time (h) & Yield $^{\mathrm{a}}$ \\
\hline \hline 1 & Yes & No & 1.0 & 12 & $0 \%$ \\
2 & No & Yes & 1.0 & 24 & $0 \%$ \\
3 & Yes & Yes & 1.0 & 8 & $60 \%$ \\
4 & Yes & Yes & 0.5 & 8 & $22 \%$ \\
5 & Yes & Yes & 1.5 & 8 & $84 \%$ \\
$\mathbf{6}$ & Yes & Yes & $\mathbf{2 . 0}$ & $\mathbf{8}$ & $\mathbf{9 6 \%}$ \\
\hline
\end{tabular}

${ }^{\text {a }}{ }^{1} \mathrm{H}$ NMR yield using 1,3,5-trimethoxybenzene as the internal standard. 

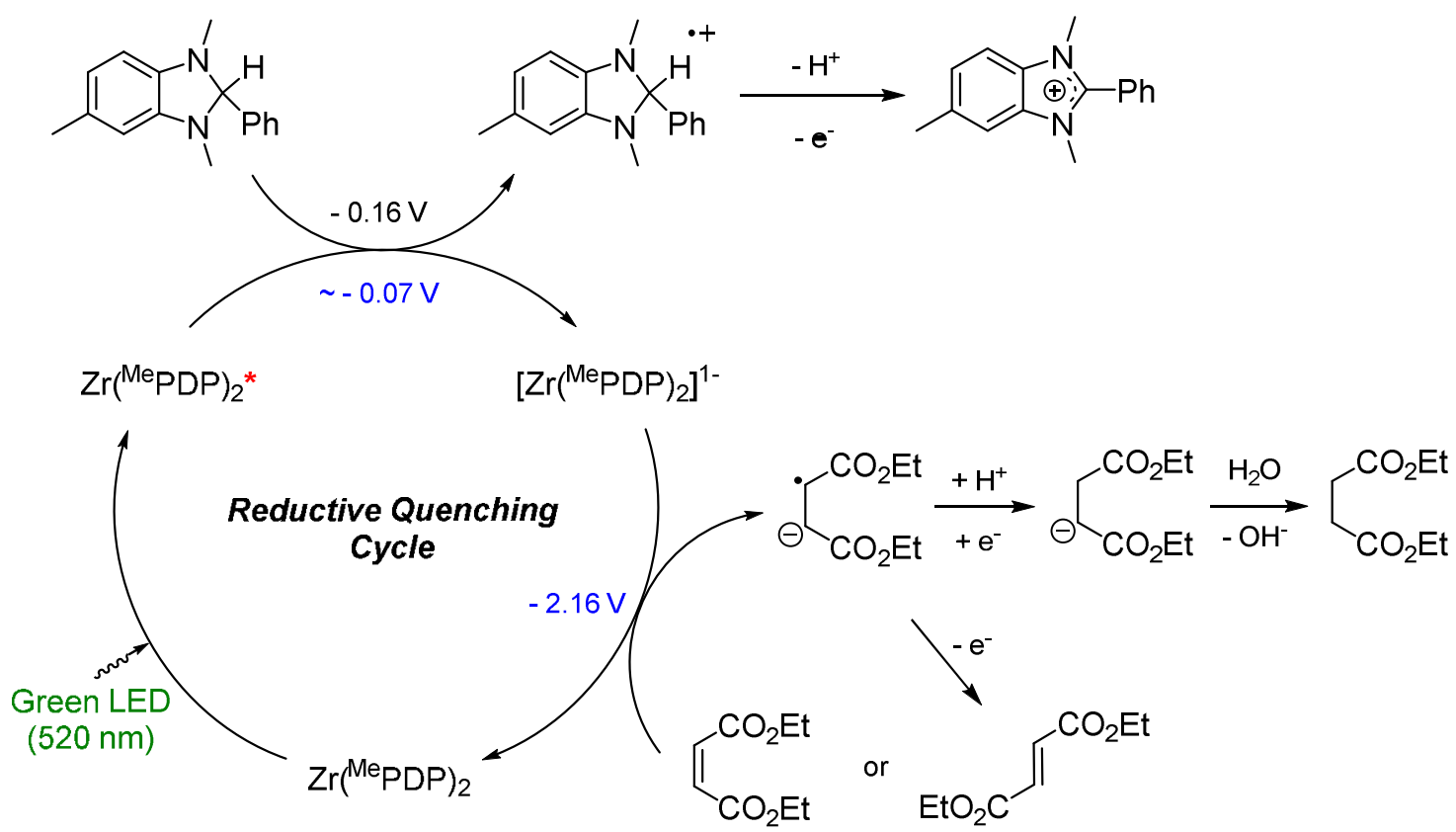

Figure S30. Proposed mechanism for the photoredox-catalyzed reduction of diethyl maleate. All potentials are given versus $\mathrm{Fc}^{+} / \mathrm{Fc}$. 


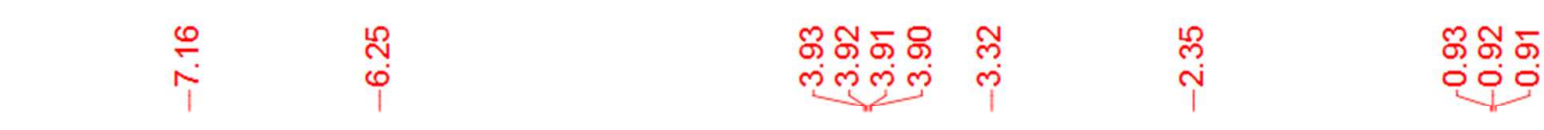

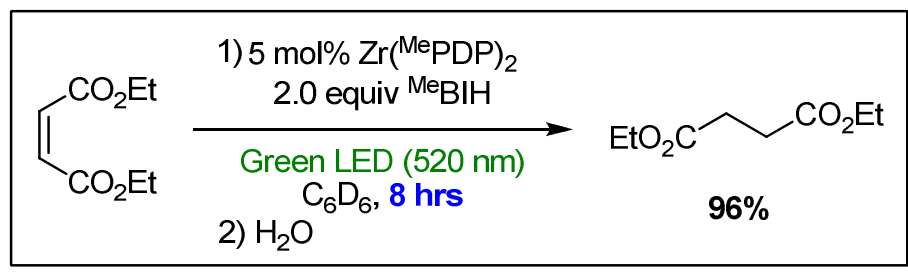

Diethyl succinate (product)

1,3,5-trimethoxybenzene

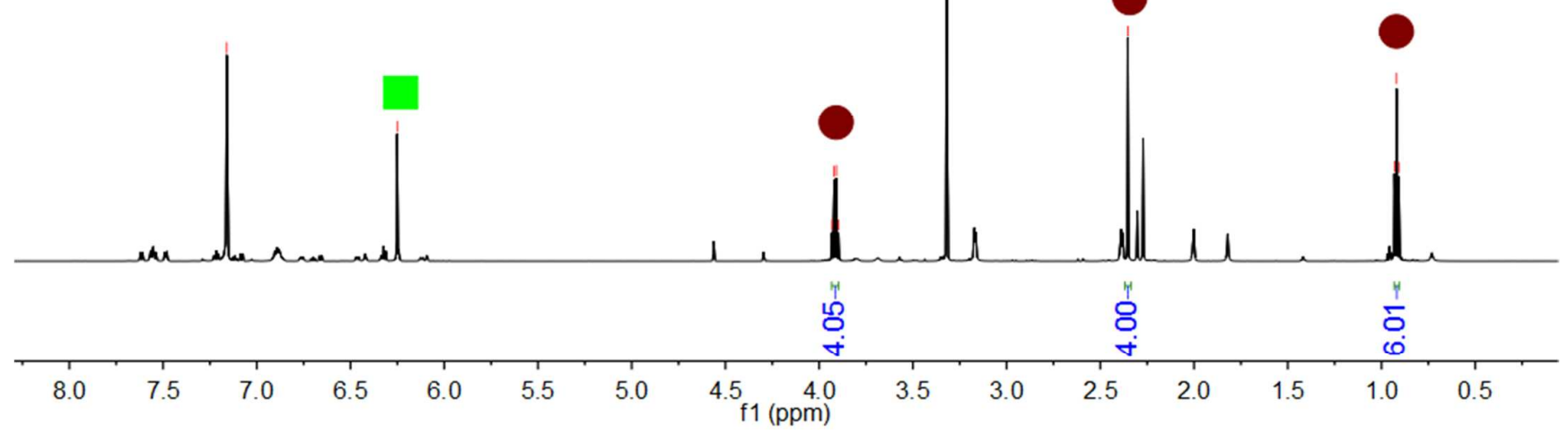

Figure S31. ${ }^{1} \mathrm{H}$ NMR spectrum of a mixture of diethyl maleate and ${ }^{\mathrm{Me}} \mathrm{BIH}$ in the presence of $\mathrm{Zr}\left({ }^{\mathrm{Me}} \mathrm{PDP}\right)_{2}$ after irradiation. 


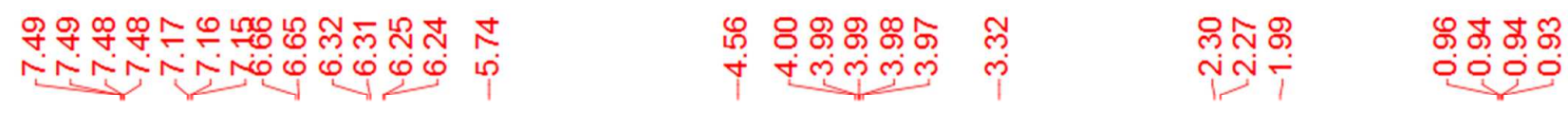

\begin{tabular}{|c|c|c|}
\hline & $\begin{array}{c}5 \mathrm{~mol} \% \mathrm{Zr}\left({ }^{\mathrm{Me}} \mathrm{PDP}\right)_{2} \\
1 \text { equiv }{ }^{\mathrm{Me}} \mathrm{BIH}\end{array}$ & No desired \\
\hline $\mathrm{CO}_{2} \mathrm{Et}$ & $\begin{array}{c}\text { Dark } \\
\mathrm{C}_{6} \mathrm{D}_{6} \text {, overnight }\end{array}$ & transfromation \\
\hline
\end{tabular}

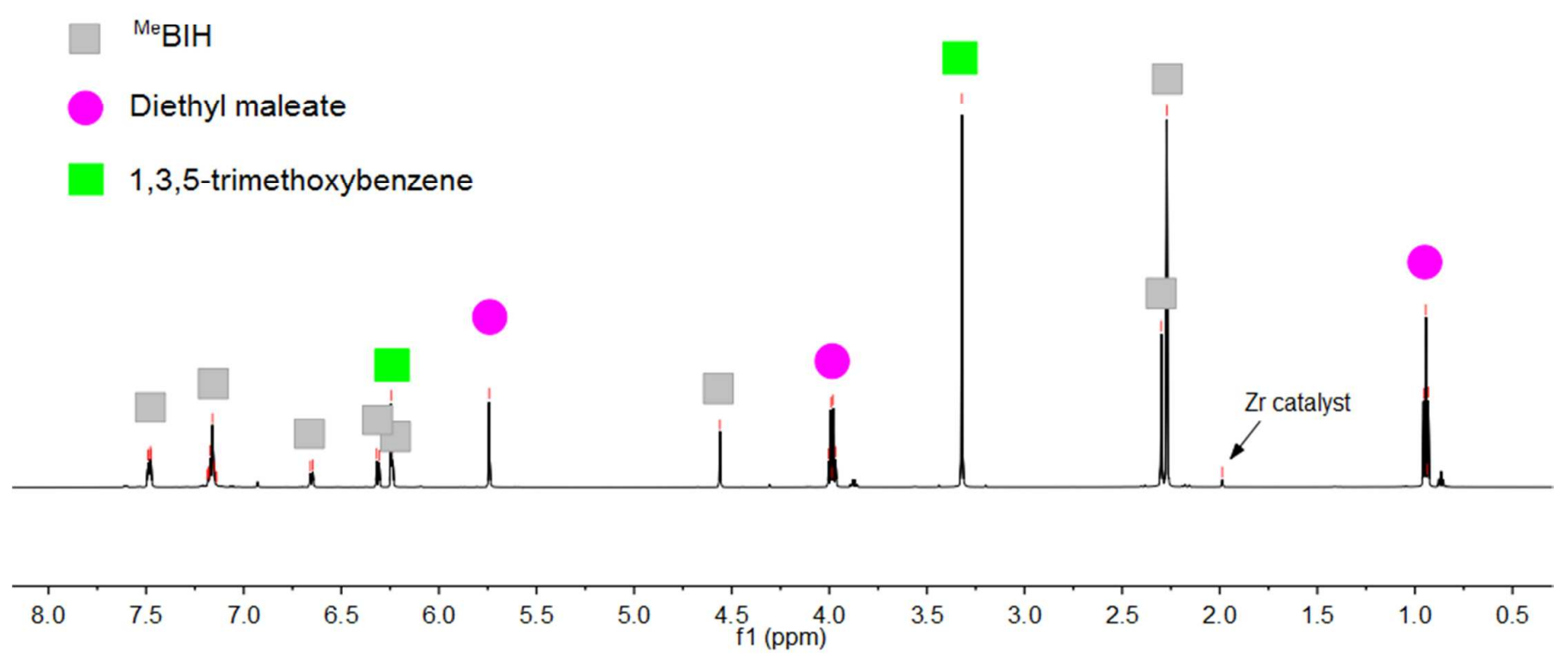

Figure S32. ${ }^{1} \mathrm{H}$ NMR spectrum of a mixture of diethyl maleate and ${ }^{\mathrm{Me}} \mathrm{BIH}$ in the presence of $\mathrm{Zr}\left({ }^{\mathrm{Me}} \mathrm{PDP}\right)_{2}$ without irradiation. 


\begin{tabular}{|c|c|c|}
\hline $\mathrm{CO}_{2} \mathrm{Et}$ & $\begin{array}{c}\left.0 \text { mol\% } \% \mathrm{Zr}^{\mathrm{Me}} \mathrm{PDP}\right)_{2} \\
1 \text { equiv }{ }^{\mathrm{Me}} \mathrm{BIH}\end{array}$ & \\
\hline $\mathrm{CO}_{2} \mathrm{Et}$ & $\begin{array}{c}\text { Green LED (520 nm) } \\
\mathrm{C}_{6} \mathrm{D}_{6}, \mathbf{2 4} \text { hrs }\end{array}$ & transfromation \\
\hline
\end{tabular}

\section{${ }^{\mathrm{Me}} \mathrm{BIH}$}

Diethyl maleate

1,3,5-trimethoxybenzene
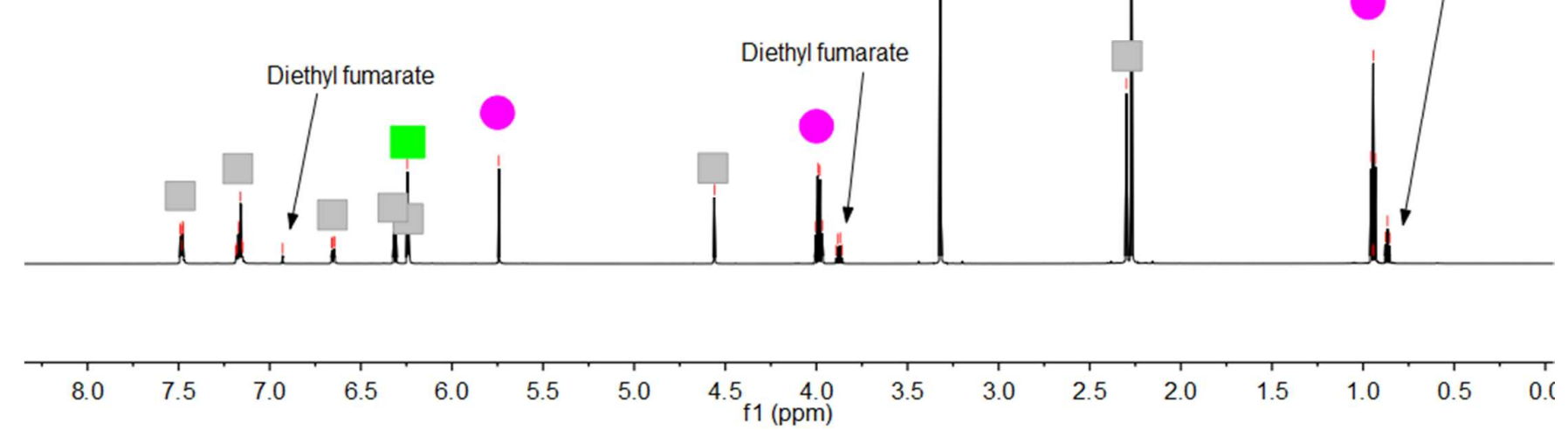

Figure S33. ${ }^{1} \mathrm{H}$ NMR spectrum of a mixture of diethyl maleate and ${ }^{\mathrm{Me}} \mathrm{BIH}$ after irradiation. 


\subsection{Reductive Coupling of Benzyl Bromide using Photoredox Catalysis}

In the drybox, a J. Young NMR tube was charged with $\mathrm{Zr}\left({ }^{\mathrm{Me}} \mathrm{PDP}\right)_{2}(1 \mathrm{mg}, 0.001 \mathrm{mmol}, 0.03$ equiv), sacrificial reductant, base and benzyl bromide (6.1 mg, $0.036 \mathrm{mmol}, 1.00$ equiv). 0.6 $\mathrm{mL}$ of $\mathrm{C}_{6} \mathrm{D}_{6}$ was added. The mixture was placed in a jacketed glass beaker with water cooling and irradiated with green LED light $\left(\lambda_{\max }=520 \mathrm{~nm}\right.$ ). After reaction was complete (as judged by NMR analysis), the products were analyzed by NMR spectroscopy and the yields are based on internal standard. Bibenzyl isolated for characterization was obtained via preparative TLC. ${ }^{1} \mathrm{H}$ NMR (600 MHz, $\mathrm{CDCl}_{3} ; \delta$, ppm): 7.30 - 7.27 (m, 4H, $\left.\mathrm{PhH}\right), 7.22$ - 7.17 (m, 6H, $\mathrm{PhH}), 2.93$ (s, 4H, $\left.\mathrm{CH}_{2} \mathrm{CH}_{2}\right) .{ }^{13} \mathrm{C} \mathrm{NMR}$ (151 MHz, $\left.\mathrm{CDCl}_{3} ; \delta, \mathrm{ppm}\right): 141.93,128.59$, 128.47, 126.05, 38.10. The ${ }^{1} \mathrm{H}$ NMR spectroscopic data of isolated bibenzyl in $\mathrm{C}_{6} \mathrm{D}_{6}$ and $\mathrm{CDCl}_{3}$ matched with commercially available pure material.

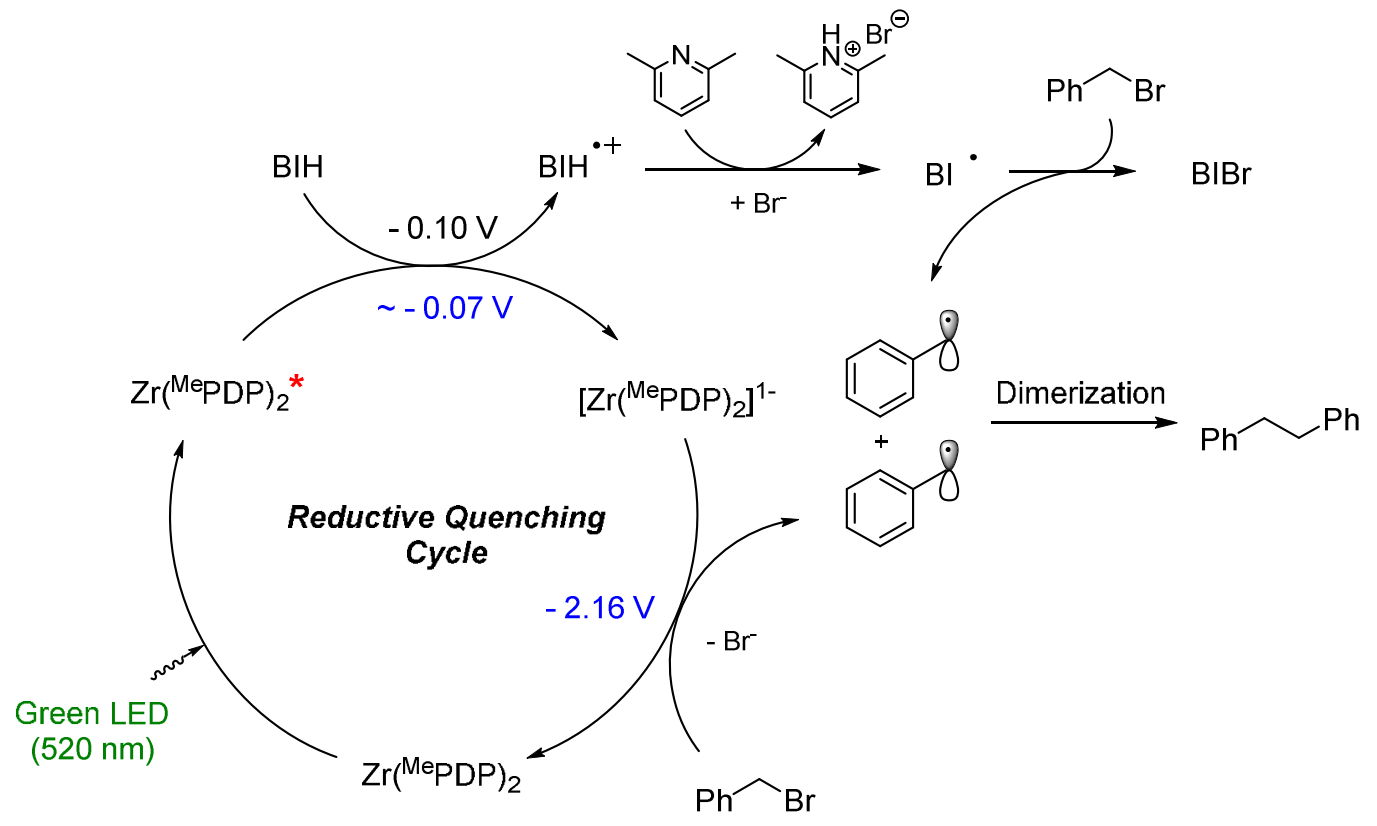

Figure S34. Proposed mechanism for the photoredox-catalyzed reductive coupling of benzyl bromide. All potentials are given versus $\mathrm{Fc}+/ \mathrm{Fc}$. 
Table S4. Optimization of reaction conditions and control experiments for the reductive coupling of benzyl bromide via photoredox catalysis.
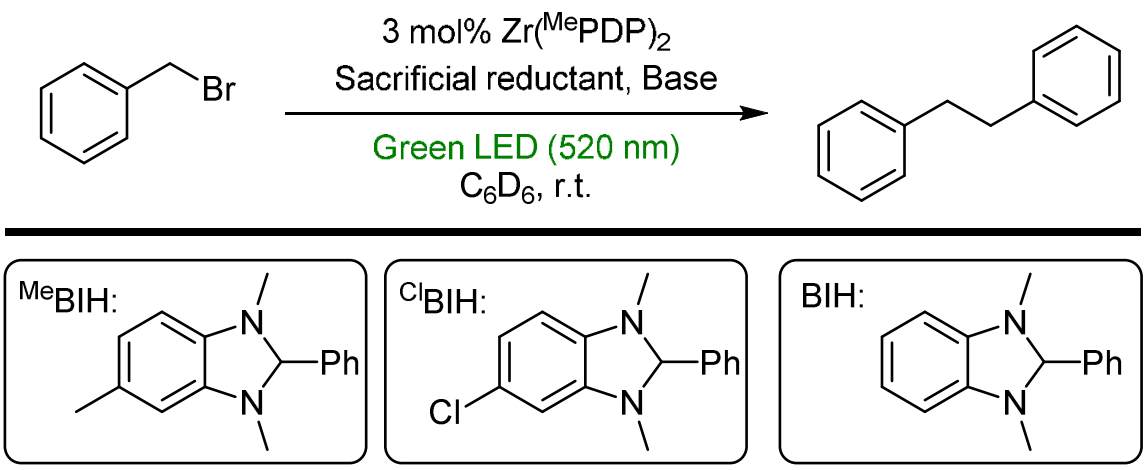

\begin{tabular}{|c|c|c|c|c|c|c|}
\hline Entry & Light & $\mathrm{Zr}\left({ }^{\mathrm{Me}} \mathrm{PDP}\right)_{2}$ & $\begin{array}{c}\text { Reductant } \\
\text { (equiv) }\end{array}$ & $\begin{array}{l}\text { Base }^{\mathrm{b}} \\
\text { (equiv) }\end{array}$ & $\begin{array}{l}\text { Time } \\
\text { (h) }\end{array}$ & $\begin{array}{l}\text { Yield \% }{ }^{\mathrm{a}} \\
\text { (Conv.\%) }\end{array}$ \\
\hline 1 & Yes & Yes & ${ }^{\mathrm{Me}} \mathrm{BIH}(1.0)$ & No & 16 & $6(47)$ \\
\hline 2 & Yes & No & ${ }^{\mathrm{Me}} \mathrm{BIH}(1.0)$ & No & 16 & N.R. \\
\hline 3 & Yes & Yes & ${ }^{\mathrm{Me}} \mathrm{BIH}(1.0)$ & Py (1.0) & 16 & $15(100)$ \\
\hline 4 & No & Yes & ${ }^{\mathrm{Me}} \mathrm{BIH}(1.0)$ & Py (1.0) & 72 & N.R. \\
\hline 5 & Yes & No & ${ }^{\mathrm{Me}} \mathrm{BIH}(1.0)$ & Py (1.0) & 24 & N.R. \\
\hline 6 & Yes & Yes & ${ }^{\mathrm{Me}} \mathrm{BIH}(0.5)$ & Py (1.0) & 24 & $16(76)$ \\
\hline 7 & Yes & Yes & BIH (1.0) & Py (2.0) & 48 & $35(63)$ \\
\hline 8 & Yes & Yes & ${ }^{\mathrm{Me}} \mathrm{BIH}(0.7)$ & $\mathrm{Lu}(2.0)$ & 24 & $30(99)$ \\
\hline 9 & Yes & Yes & $\mathrm{BIH}(0.7)$ & $\mathrm{Lu}(2.0)$ & 48 & $20(21)$ \\
\hline 10 & Yes & Yes & ${ }^{\mathrm{Cl}} \mathrm{BIH}(0.7)$ & $\mathrm{Lu}(2.0)$ & 108 & $29(31)$ \\
\hline $11^{\mathrm{c}}$ & Yes & Yes & $\mathrm{BIH}(0.7)$ & $\mathrm{Lu}(2.0)$ & 45 & 40 \\
\hline
\end{tabular}

${ }^{\text {a }} \mathrm{H}$ NMR yield using 1,3,5-trimethoxybenzene as the internal standard.

${ }^{\mathrm{b}} \mathrm{Py}=$ pyridine, $\mathrm{Lu}=2,6$-lutidine.

${ }^{c}$ Scaled-up experiment using $81 \mathrm{mg}$ of benzyl bromide in $\mathrm{C}_{6} \mathrm{H}_{6}$ solution. The reaction mixture was stirred in a $50 \mathrm{~mL}$ thick-walled glass vessel with a Teflon screw cap during irradiation. 


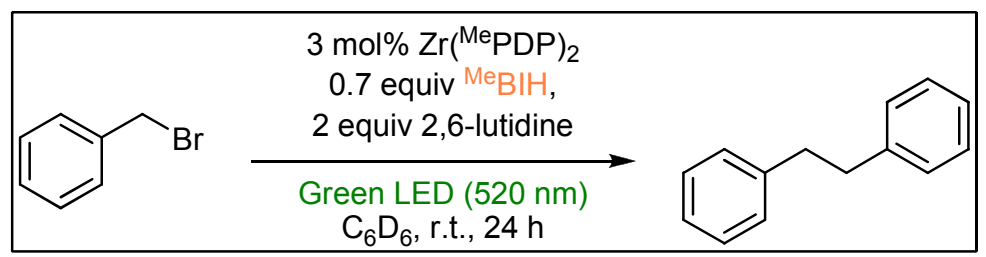

1,3,5-trimethoxybenzene $\mathrm{C}_{6} \mathrm{D}_{6}$, r.t., $24 \mathrm{~h}$

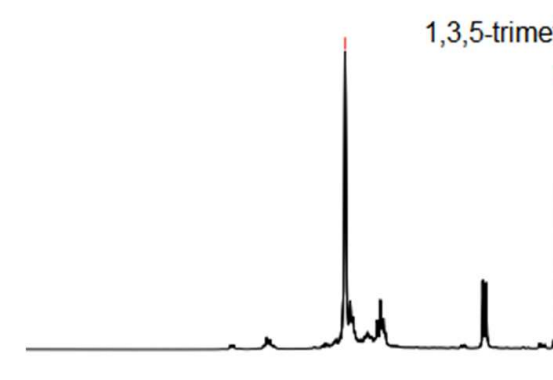

\section{,5-trimethoxybenzne}

$$
5
$$

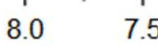

7.0

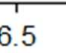

6.0

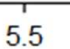

5.0 (ppm)

2,6-lutidine

Figure S35. ${ }^{1} \mathrm{H}$ NMR spectrum of a mixture of benzyl bromide, ${ }^{\mathrm{Me}} \mathrm{BIH}$, and 2,6-lutidine in the presence of $\mathrm{Zr}\left({ }^{\mathrm{Me}} \mathrm{PDP}\right)_{2}$ after irradiation. 


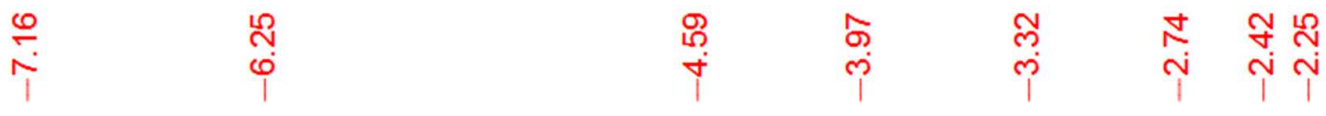

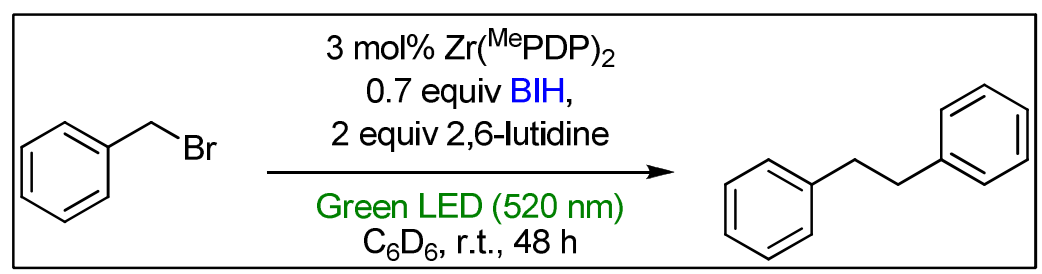

1,3,5-trimethoxybenzene
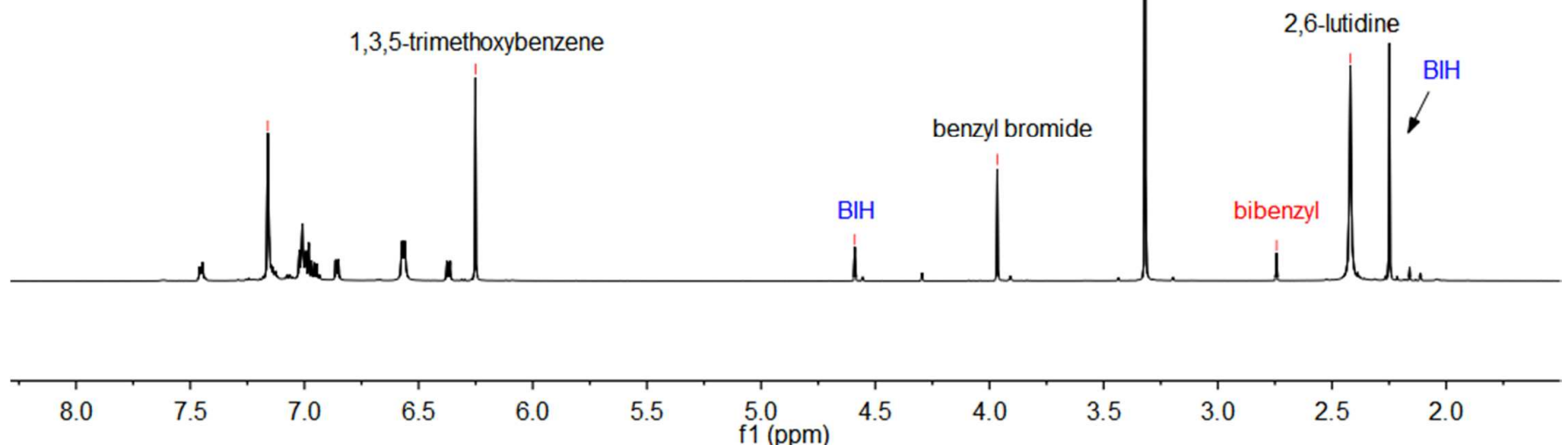

Figure S36. ${ }^{1} \mathrm{H}$ NMR spectrum of a mixture of benzyl bromide, BIH, and 2,6-lutidine in the presence of $\mathrm{Zr}\left({ }^{\mathrm{Me}} \mathrm{PDP}\right)_{2}$ after irradiation. 


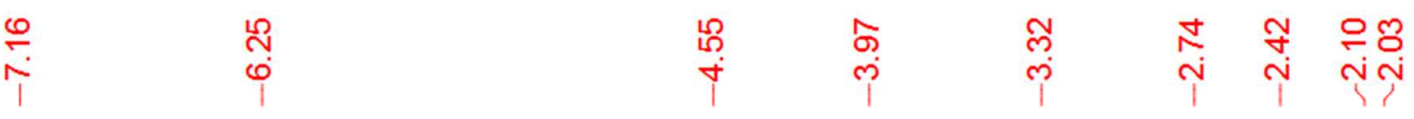

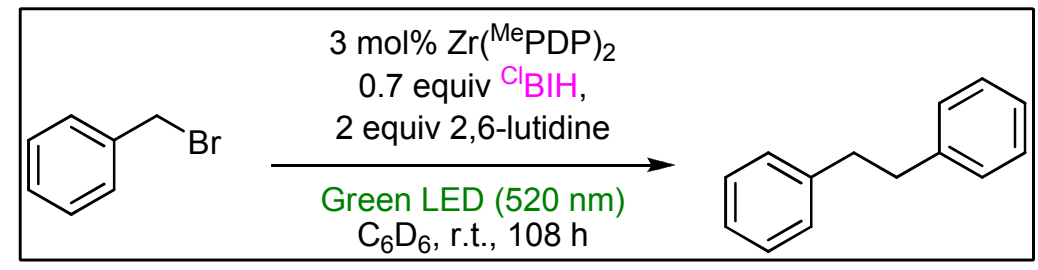

1,3,5-trimethoxybenzene
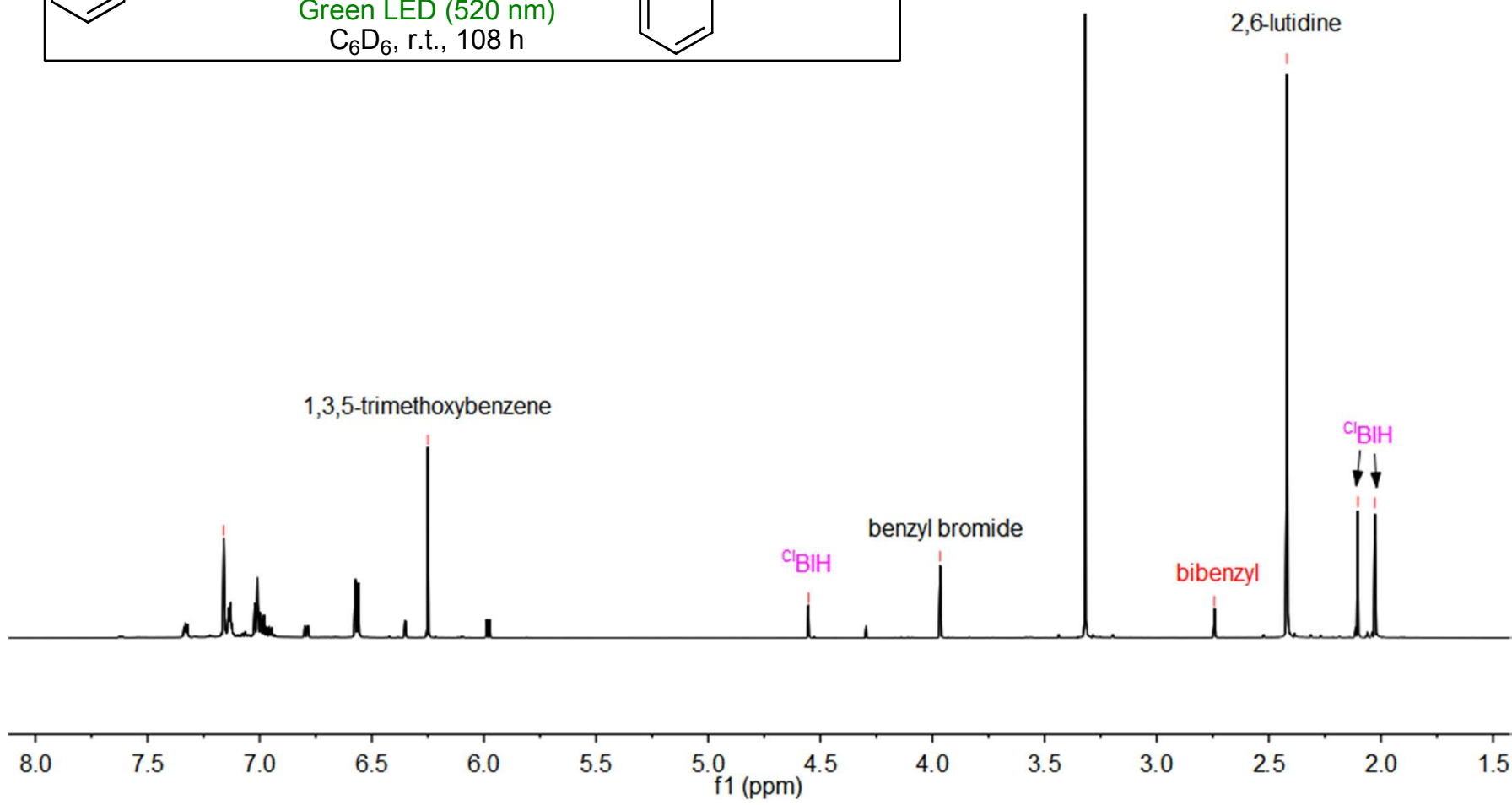

Figure S37. ${ }^{1} \mathrm{H}$ NMR spectrum of a mixture of benzyl bromide, ${ }^{\mathrm{Cl}} \mathrm{BIH}$, and 2,6-lutidine in the presence of $\mathrm{Zr}\left({ }^{\mathrm{Me}} \mathrm{PDP}\right)_{2}$ after irradiation. 


\section{DFT Calculations}

All DFT calculations were performed with the ORCA program package. ${ }^{14}$ Geometry optimizations of the complexes and single-point calculations on the optimized geometries were carried out at the B3LYP level of DFT. ${ }^{15-17}$ The all-electron Gaussian basis sets were those developed by the Ahlrichs group. ${ }^{18-20}$ Triple- $\zeta$ quality basis sets def2-TZVP with one set of polarization functions on the metal and on the atoms directly coordinated to the metal center were used. For the carbon and hydrogen atoms, slightly smaller polarized split-valence def2-SVP basis sets were used that were of double- $\zeta$ quality in the valence region and contained a polarizing set of $\mathrm{d}$ functions on the non-hydrogen atoms. Auxiliary basis sets to expand the electron density in the resolution-of-the-identity (RIJCOSX) ${ }^{21-23}$ approach were chosen to match the orbital basis. ${ }^{24-26}$ Time-dependent DFT calculations were performed at the B3LYP level of theory. The conductor-like screening model (COSMO) was applied to model the solvent effects of THF. ${ }^{27}$ All molecular orbital and spin density plots were generated using the program Gabedit. ${ }^{28}$

\subsection{Input File Examples}

Geometry Optimizations

! RKS B3LYP RIJCOSX SlowConv TightSCF def2-SVP def2-SVP/J Normalprint Opt

\%basis NewGTO 40 "def2-TZVP(-f)" end

NewGTO 7 "def2-TZVP(-f)" end

NewAuxGTO 40 "def2-TZVP/J" end

NewAuxGTO 7 "def2-TZVP/J" end

end

$\%$ scf MaxIter 500

TolE 1E-7

TolErr 1E-6

end

*xyz 01

xyz coordinates from X-ray structure

$*$ 


\section{TD-DFT Calculations}

! RKS B3LYP RIJCOSX SlowConv TightSCF def2-SVP def2-SVP/J COSMO(THF)

\%basis NewGTO 40 "def2-TZVP(-f)" end

NewGTO 7 "def2-TZVP(-f)" end

NewAuxGTO 40 "def2-TZVP/J" end

NewAuxGTO 7 "def2-TZVP/J" end

end

$\%$ scf MaxIter 500

TolE 1E-7

TolErr 1E-6

end

\%tddft nroots 50

MaxDim 500

triplets false

end

*xyz 01

xyz coordinates from geometry optimization

*

\subsection{TD-DFT Results}

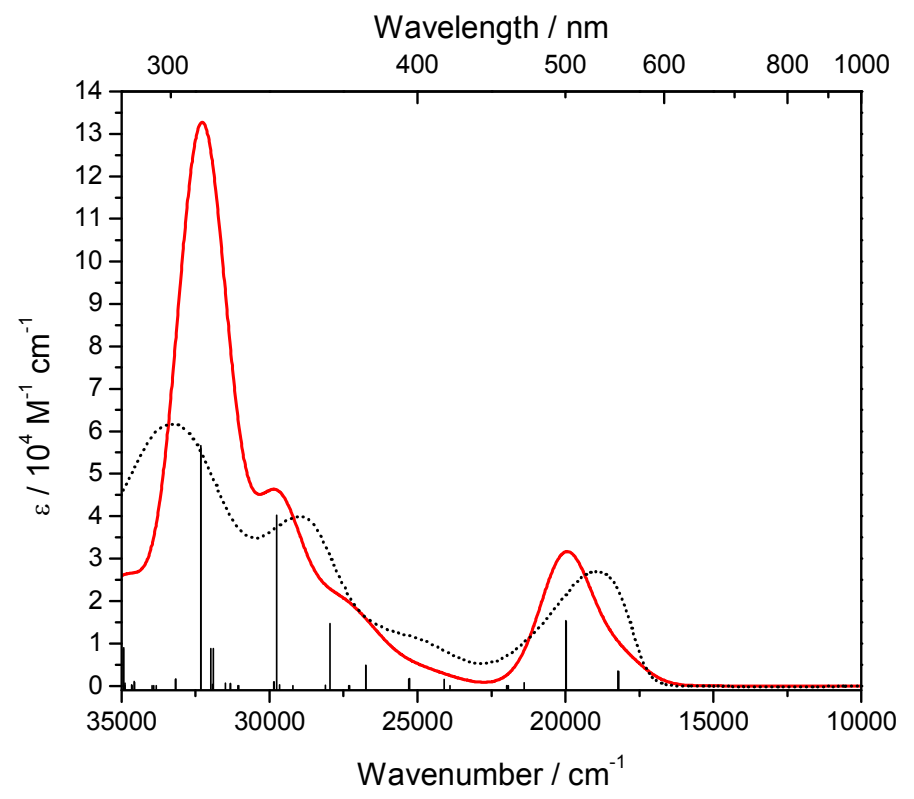

Figure S38. TD-DFT (COSMO) predicted electronic absorption spectrum of $\mathrm{Zr}\left({ }^{\mathrm{Me}} \mathrm{PDP}\right)_{2}$ between 35000 and $10000 \mathrm{~cm}^{-1}$ (red line). The calculated spectrum was plotted using Gaussian line shapes with a fwhm of $2000 \mathrm{~cm}^{-1}$. The vertical bars indicate the position of the predicted transitions. The experimental spectrum is shown as a dotted line for comparison. 


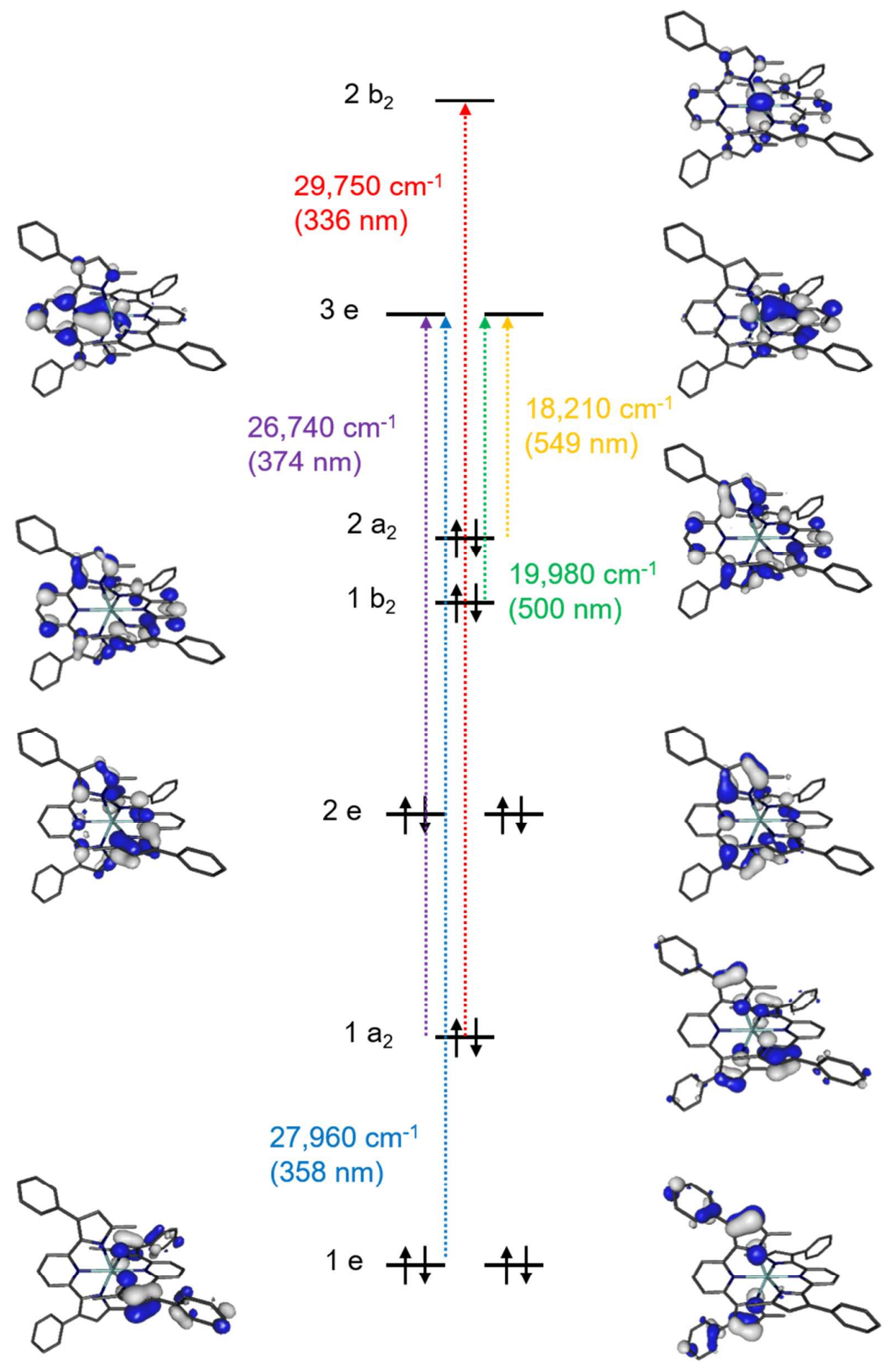

Figure S39. Qualitative MO scheme for $\mathrm{Zr}\left({ }^{\mathrm{Me}} \mathrm{PDP}\right)_{2}$. Distances between the orbitals are not quantitative representations of the calculated differences in orbital energy. Dotted arrows indicate major contributions to the transitions in the calculated electronic absorption spectrum. Symmetry labels are given for idealized $\mathrm{D}_{2 \mathrm{~d}}$ symmetry observed in solution by NMR spectroscopy. 


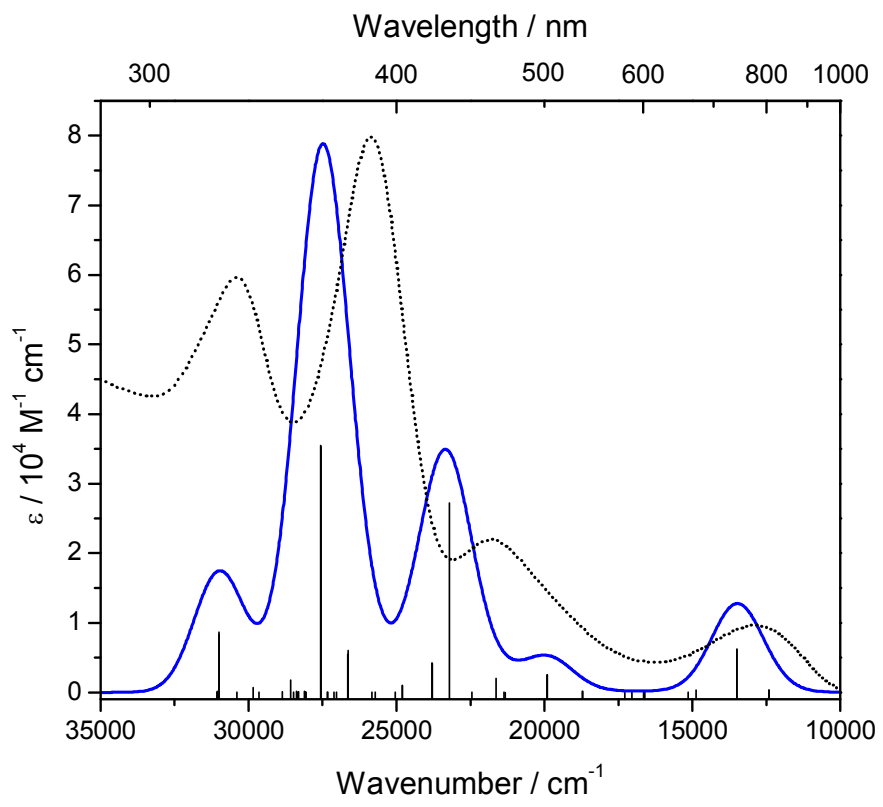

Figure S40. TD-DFT $\left(\right.$ COSMO) predicted electronic absorption spectrum of $\mathrm{Ti}\left({ }^{\mathrm{Me}} \mathrm{PDP}\right)_{2}$ between 35000 and $10000 \mathrm{~cm}^{-1}$ (blue line). The calculated spectrum was plotted using Gaussian line shapes with a fwhm of $2000 \mathrm{~cm}^{-1}$. The vertical bars indicate the position of the predicted transitions. The experimental spectrum is shown as a dotted line for comparison. 


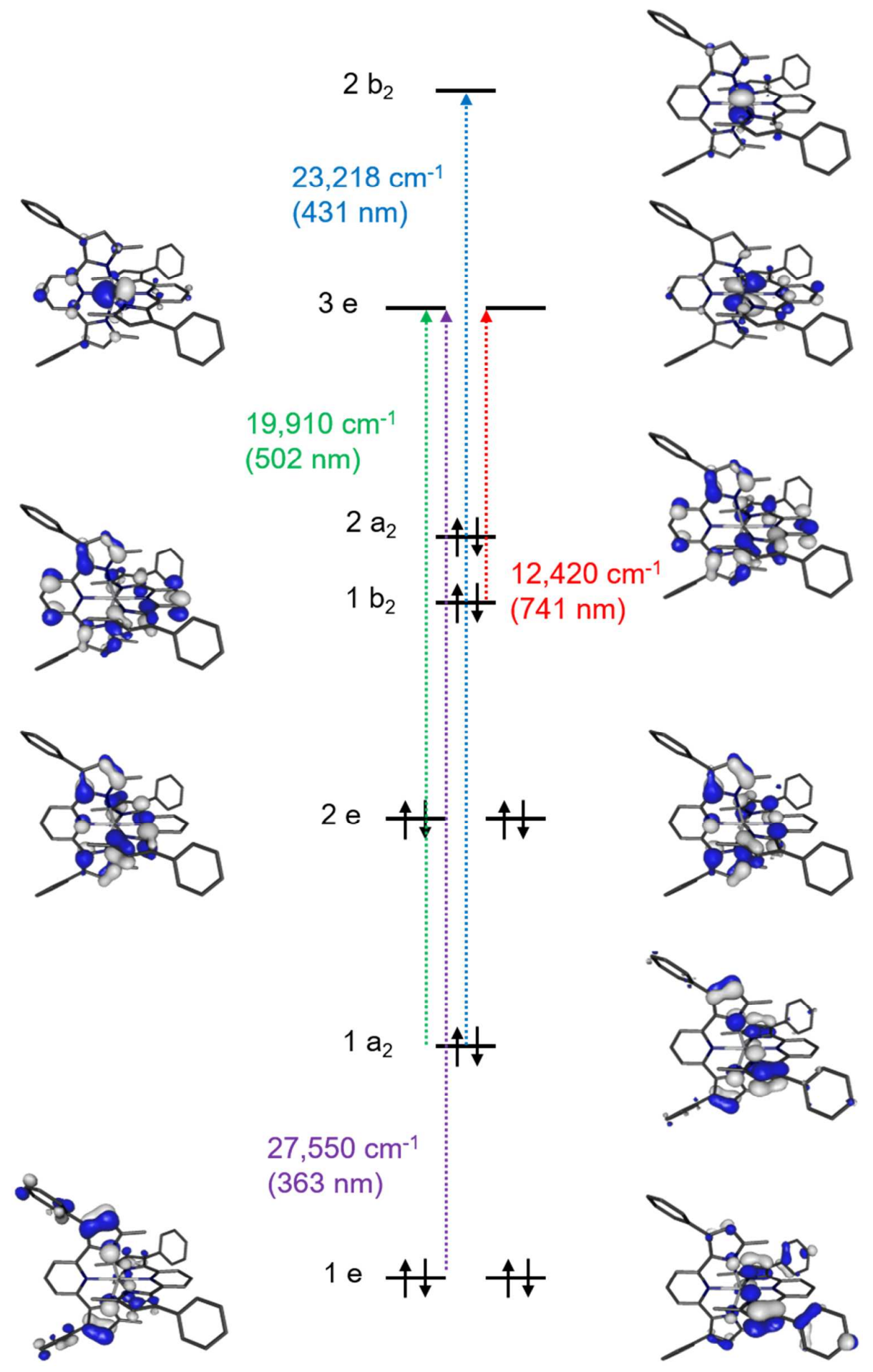

Figure S41. Qualitative MO scheme for $\mathrm{Ti}\left({ }^{\mathrm{Me}} \mathrm{PDP}\right)_{2}$. Distances between the orbitals are not quantitative representations of the calculated differences in orbital energy. Dotted arrows indicate major contributions to the transitions in the calculated electronic absorption spectrum. Symmetry labels are given for idealized $\mathrm{D}_{2 \mathrm{~d}}$ symmetry observed in solution by NMR spectroscopy. 


\subsection{Optimized Geometries}

$\begin{array}{llll}\mathbf{Z r}\left({ }^{\mathrm{Me}} \mathbf{P D P}\right)_{2} & & \\ \mathrm{Zr} & -0.021634 & 0.033219 & -0.001960 \\ \mathrm{~N} & 2.312684 & -0.025715 & -0.016193 \\ \mathrm{~N} & -2.356042 & 0.092772 & -0.013185 \\ \mathrm{~N} & 0.745257 & -0.330114 & 2.022182 \\ \mathrm{~N} & -0.734768 & 2.078297 & 0.353120 \\ \mathrm{~N} & -0.832023 & -1.977296 & -0.342792 \\ \mathrm{~N} & 0.735598 & 0.354086 & -2.036129 \\ \mathrm{C} & 0.074823 & -0.489286 & 3.211982 \\ \mathrm{C} & -0.925962 & 4.309192 & 0.609215 \\ \mathrm{C} & 1.457844 & 3.279466 & 0.664037 \\ \mathrm{C} & -0.032854 & 3.246327 & 0.535723 \\ \mathrm{C} & -4.447814 & 4.452244 & 1.555368 \\ \mathrm{C} & -2.246220 & 3.789556 & 0.499017 \\ \mathrm{C} & -2.090330 & 2.401053 & 0.338890 \\ \mathrm{C} & -3.478574 & 4.616812 & 0.545449 \\ \mathrm{C} & -5.588868 & 5.259363 & 1.598096 \\ \mathrm{C} & -4.825503 & 6.439651 & -0.367852 \\ \mathrm{C} & -3.682838 & 5.634208 & -0.408095 \\ \mathrm{C} & -5.785626 & 6.252730 & 0.632289 \\ \mathrm{C} & -3.702455 & -4.350910 & -0.687540 \\ \mathrm{C} & -3.994940 & -5.395312 & 0.211756 \\ \mathrm{C} & -5.807346 & -4.824707 & -1.834353 \\ \mathrm{C} & -2.429545 & -3.598183 & -0.568378 \\ \mathrm{C} & -4.626800 & -4.085265 & -1.717850 \\ \mathrm{C} & -0.189734 & -3.179543 & -0.527464 \\ \mathrm{C} & -5.176362 & -6.134730 & 0.096406 \\ \mathrm{C} & -2.202838 & -2.224725 & -0.372415 \\ \mathrm{C} & -1.137564 & -4.189125 & -0.648941 \\ \mathrm{C} & 1.300002 & -3.294964 & -0.610006 \\ \mathrm{C} & 2.110028 & -0.363847 & 2.301012 \\ \mathrm{C} & 3.557392 & -0.630953 & 4.473192 \\ \mathrm{C} & 4.493535 & -1.663008 & 4.260935 \\ \mathrm{C} & 0.998257 & -0.596881 & 4.245378 \\ \mathrm{C} & 2.304309 & -0.533063 & 3.683670 \\ \mathrm{C} & 5.652922 & -1.755543 & 5.036989 \\ \mathrm{C} & 3.815672 & 0.294134 & 5.504589 \\ \mathrm{C} & 5.902443 & -0.818453 & 6.045859 \\ \mathrm{C} & 3.097101 & 0.317772 & -2.331164 \\ \mathrm{C} & 0.976621 & 0.597677 & -4.263861 \\ & 1.507850 & -4.336891\end{array}$




$\begin{array}{llll}\mathrm{C} & -1.426856 & 0.693982 & -3.285883 \\ \mathrm{C} & 0.060565 & 0.541878 & -3.219631 \\ \mathrm{C} & 3.756701 & -0.460693 & -5.521449 \\ \mathrm{C} & 2.284002 & 0.470097 & -3.716381 \\ \mathrm{C} & -3.050560 & -1.070246 & -0.178034 \\ \mathrm{C} & -2.992825 & 1.290098 & 0.140093 \\ \mathrm{C} & -4.395430 & 1.350995 & 0.100132 \\ \mathrm{C} & -4.455094 & -1.060550 & -0.152192 \\ \mathrm{C} & -5.112402 & 0.162445 & -0.028543 \\ \mathrm{C} & -6.090147 & -5.848639 & -0.923391 \\ \mathrm{C} & 2.974714 & 0.110528 & -1.201839 \\ \mathrm{C} & 4.377591 & 0.048015 & -1.235675 \\ \mathrm{C} & 2.982391 & -0.192943 & 1.161256 \\ \mathrm{C} & 4.386887 & -0.190486 & 1.177958 \\ \mathrm{C} & 5.069463 & -0.084992 & -0.032851 \\ \mathrm{C} & 5.663398 & 1.539579 & -5.118956 \\ \mathrm{C} & 5.877311 & 0.565708 & -6.100795 \\ \mathrm{C} & 4.917120 & -0.431577 & -6.301599 \\ \mathrm{C} & 4.975969 & 0.203257 & 6.279996 \\ \mathrm{C} & -1.417651 & -0.562259 & 3.291939 \\ \mathrm{H} & -0.662541 & 5.353983 & 0.771932 \\ \mathrm{H} & 1.814579 & 2.588156 & 1.445357 \\ \mathrm{H} & 1.793047 & 4.290160 & 0.938688 \\ \mathrm{H} & 0.737431 & 0.760816 & -5.314455 \\ \mathrm{H} & 4.339707 & 2.277690 & -3.578301 \\ \mathrm{H} & 1.965111 & 3.000181 & -0.275313 \\ \mathrm{H} & -4.296062 & 3.684905 & 2.319264 \\ \mathrm{H} & -6.325844 & 5.113223 & 2.393439 \\ \mathrm{H} & -4.969943 & 7.216309 & -1.124612 \\ \mathrm{H} & -2.937914 & 5.785106 & -1.194220 \\ \mathrm{H} & -6.681305 & 6.879321 & 0.660648 \\ \mathrm{H} & -3.286001 & -5.619622 & 1.013072 \\ \mathrm{H} & -6.508700 & -4.601647 & -2.643583 \\ \mathrm{H} & -4.406816 & -3.294808 & -2.440057 \\ \mathrm{H} & -5.387670 & -6.935885 & 0.810419 \\ \mathrm{H} & -0.927715 & -5.243439 & -0.827645 \\ \mathrm{H} & 1.720016 & -2.621321 & -1.375085 \\ \mathrm{H} & 1.586448 & -4.321619 & -0.880817 \\ \mathrm{H} & 4.299953 & -2.406271 & 3.483120 \\ \mathrm{H} & 0.763130 & -0.753771 & 5.297822 \\ & -2.567451 & 4.854586 \\ & & \\ \mathrm{H} & & \\ \mathrm{H} & & \end{array}$




$\begin{array}{llll}\mathrm{H} & -1.955237 & -0.232915 & -3.004551 \\ \mathrm{H} & -1.736063 & 0.959798 & -4.307232 \\ \mathrm{H} & -1.785279 & 1.491012 & -2.613487 \\ \mathrm{H} & 3.011122 & -1.243978 & -5.683356 \\ \mathrm{H} & -4.903990 & 2.308301 & 0.192898 \\ \mathrm{H} & -5.009780 & -1.991265 & -0.249785 \\ \mathrm{H} & -6.205738 & 0.190597 & -0.032693 \\ \mathrm{H} & -7.015357 & -6.424198 & -1.011606 \\ \mathrm{H} & 4.905513 & 0.125898 & -2.183778 \\ \mathrm{H} & 4.922171 & -0.291726 & 2.119609 \\ \mathrm{H} & 6.162892 & -0.108216 & -0.039490 \\ \mathrm{H} & 6.400988 & 2.332339 & -4.962278 \\ \mathrm{H} & 6.786766 & 0.585013 & -6.707481 \\ \mathrm{H} & 5.075508 & -1.194670 & -7.069248 \\ \mathrm{H} & 5.161066 & 0.937825 & 7.069091 \\ \mathrm{H} & -1.825833 & -1.325065 & 2.608398 \\ \mathrm{H} & -1.896909 & 0.397572 & 3.033489 \\ \mathrm{H} & -1.730732 & -0.830257 & 4.311465\end{array}$

$\begin{array}{llll}\mathbf{T i}\left({ }^{\mathrm{Me}} \mathbf{P D P}\right)_{\mathbf{2}} & & \\ \mathrm{Ti} & -0.052854 & -0.054028 & 0.023748 \\ \mathrm{~N} & -0.067570 & -0.068089 & -2.132128 \\ \mathrm{~N} & -0.009730 & -0.001127 & 2.178802 \\ \mathrm{~N} & 0.395867 & 1.883465 & -0.571272 \\ \mathrm{~N} & -1.979346 & 0.404158 & 0.633709 \\ \mathrm{~N} & 1.891042 & -0.523059 & 0.575697 \\ \mathrm{~N} & -0.525642 & -1.987924 & -0.542674 \\ \mathrm{C} & 0.616536 & 3.048162 & 0.125973 \\ \mathrm{C} & -4.200260 & 0.728292 & 0.845946 \\ \mathrm{C} & -3.228194 & 0.694178 & -1.549517 \\ \mathrm{C} & -3.150187 & 0.599944 & -0.059869 \\ \mathrm{C} & -4.256489 & 1.728519 & 4.370733 \\ \mathrm{C} & -3.670078 & 0.642784 & 2.161359 \\ \mathrm{C} & -2.288673 & 0.441506 & 1.989572 \\ \mathrm{C} & -4.473824 & 0.724739 & 3.405588 \\ \mathrm{C} & -5.037207 & 1.795426 & 5.528914 \\ \mathrm{C} & -6.295203 & -0.132088 & 4.791201 \\ \mathrm{C} & -5.516209 & -0.196706 & 3.631755 \\ \mathrm{C} & -6.055076 & 0.860392 & 5.747538 \\ \mathrm{C} & 4.496637 & -0.660937 & 3.259690 \\ \mathrm{C} & 5.533911 & 0.283204 & 3.397204 \\ \mathrm{C} & 5.150118 & -1.610004 & 5.414599 \\ \mathrm{C} & 3.645594 & -0.658718 & 2.044004 \\ \mathrm{C} & 4.328068 & -1.614575 & 4.283542\end{array}$




\begin{tabular}{|c|c|c|c|}
\hline C & 3.031459 & -0.775061 & -0.150578 \\
\hline $\mathrm{C}$ & 6.353312 & 0.290985 & 4.530392 \\
\hline $\mathrm{C}$ & 2.258507 & -0.464679 & 1.916462 \\
\hline $\mathrm{C}$ & 4.119182 & -0.841453 & 0.717442 \\
\hline $\mathrm{C}$ & 3.051491 & -0.988791 & -1.630560 \\
\hline $\mathrm{C}$ & 0.374095 & 2.209888 & -1.924149 \\
\hline $\mathrm{C}$ & 0.589891 & 4.409927 & -3.328108 \\
\hline $\mathrm{C}$ & 1.576452 & 4.225620 & -4.317498 \\
\hline $\mathrm{C}$ & 0.700258 & 4.109372 & -0.772755 \\
\hline $\mathrm{C}$ & 0.560726 & 3.594059 & -2.088737 \\
\hline $\mathrm{C}$ & 1.597194 & 5.016734 & -5.470352 \\
\hline $\mathrm{C}$ & -0.362341 & 5.430339 & -3.523833 \\
\hline $\mathrm{C}$ & 0.631962 & 6.012180 & -5.658812 \\
\hline $\mathrm{C}$ & -0.510785 & -2.341756 & -1.887888 \\
\hline $\mathrm{C}$ & -0.726071 & -4.573879 & -3.240423 \\
\hline $\mathrm{C}$ & -0.828420 & -4.216502 & -0.691872 \\
\hline $\mathrm{C}$ & -1.695502 & -4.396310 & -4.247873 \\
\hline $\mathrm{C}$ & -0.894331 & -3.161505 & 1.669404 \\
\hline $\mathrm{C}$ & -0.741098 & -3.135868 & 0.182429 \\
\hline $\mathrm{C}$ & 0.210641 & -5.615275 & -3.398714 \\
\hline $\mathrm{C}$ & -0.696334 & -3.729665 & -2.020632 \\
\hline $\mathrm{C}$ & 1.177778 & -0.191748 & 2.824208 \\
\hline $\mathrm{C}$ & -1.167845 & 0.227542 & 2.864509 \\
\hline $\mathrm{C}$ & -1.163195 & 0.240615 & 4.268414 \\
\hline $\mathrm{C}$ & 1.236679 & -0.117416 & 4.225183 \\
\hline $\mathrm{C}$ & 0.052533 & 0.083225 & 4.933348 \\
\hline $\mathrm{C}$ & 6.162180 & -0.652390 & 5.545504 \\
\hline $\mathrm{C}$ & -0.273282 & -1.246946 & -2.789514 \\
\hline $\mathrm{C}$ & -0.243439 & -1.284560 & -4.192273 \\
\hline $\mathrm{C}$ & 0.134373 & 1.101045 & -2.806751 \\
\hline $\mathrm{C}$ & 0.102269 & 1.117504 & -4.210884 \\
\hline $\mathrm{C}$ & -0.070393 & -0.088531 & -4.888641 \\
\hline $\mathrm{C}$ & -1.713160 & -5.212920 & -5.382814 \\
\hline $\mathrm{C}$ & -0.762597 & -6.228677 & -5.534515 \\
\hline $\mathrm{C}$ & 0.195881 & -6.429490 & -4.535465 \\
\hline $\mathrm{C}$ & -0.344669 & 6.218707 & -4.678712 \\
\hline $\mathrm{C}$ & 0.783324 & 3.117904 & 1.610153 \\
\hline $\mathrm{H}$ & -5.242355 & 0.913790 & 0.587061 \\
\hline $\mathrm{H}$ & -2.532327 & 1.449225 & -1.946236 \\
\hline $\mathrm{H}$ & -4.244989 & 0.983377 & -1.852779 \\
\hline $\mathrm{H}$ & -2.986636 & -0.262291 & -2.041057 \\
\hline $\mathrm{H}$ & -3.470479 & 2.469217 & 4.201788 \\
\hline $\mathrm{H}$ & -4.850052 & 2.584746 & 6.262925 \\
\hline $\mathrm{H}$ & -7.091819 & -0.864190 & 4.952426 \\
\hline
\end{tabular}




$\begin{array}{llll}\mathrm{H} & -5.705327 & -0.977433 & 2.890099 \\ \mathrm{H} & -6.660749 & 0.907226 & 6.656601 \\ \mathrm{H} & 5.688173 & 1.024886 & 2.608477 \\ \mathrm{H} & 4.999234 & -2.360726 & 6.196219 \\ \mathrm{H} & 3.544569 & -2.370750 & 4.183611 \\ \mathrm{H} & 7.144940 & 1.040319 & 4.623407 \\ \mathrm{H} & 5.148494 & -1.052587 & 0.428867 \\ \mathrm{H} & 2.318031 & -1.748871 & -1.939065 \\ \mathrm{H} & 4.046806 & -1.336739 & -1.943769 \\ \mathrm{H} & 2.824584 & -0.067737 & -2.192046 \\ \mathrm{H} & 2.339180 & 3.455881 & -4.172171 \\ \mathrm{H} & 0.892518 & 5.149182 & -0.509638 \\ \mathrm{H} & 2.374060 & 4.855464 & -6.223731 \\ \mathrm{H} & -1.130069 & 5.595557 & -2.762914 \\ \mathrm{H} & 0.641629 & 6.625394 & -6.564114 \\ \mathrm{H} & -1.018830 & -5.250549 & -0.405799 \\ \mathrm{H} & -2.447600 & -3.611352 & -4.131411 \\ \mathrm{H} & 0.050669 & -2.939683 & 2.192147 \\ \mathrm{H} & -1.233228 & -4.156171 & 1.994107 \\ \mathrm{H} & -1.636799 & -2.424773 & 2.011451 \\ \mathrm{H} & 0.964856 & -5.776361 & -2.623434 \\ \mathrm{H} & -2.090863 & 0.396018 & 4.815161 \\ \mathrm{H} & 2.188080 & -0.240561 & 4.738519 \\ \mathrm{H} & 0.078197 & 0.118907 & 6.026104 \\ \mathrm{H} & 6.799895 & -0.641585 & 6.433883 \\ \mathrm{H} & -0.378377 & -2.229097 & -4.715180 \\ \mathrm{H} & 0.236162 & 2.054100 & -4.748142 \\ \mathrm{H} & -0.070556 & -0.097002 & -5.982260 \\ \mathrm{H} & -2.476086 & -5.055246 & -6.151111 \\ \mathrm{H} & -0.769693 & -6.862030 & -6.425987 \\ \mathrm{H} & 0.939623 & -7.224318 & -4.644397 \\ \mathrm{H} & -1.100662 & 6.997169 & -4.817327 \\ \mathrm{H} & 1.555316 & 2.418653 & 1.965295 \\ \mathrm{H} & -0.147695 & 2.878596 & 2.149143 \\ \mathrm{H} & 1.090870 & 4.132608 & 1.902680\end{array}$

\section{References}

(1) Peng, Y.; Li, Z.; Zeng, Y.; Xie, X.; Wang, H.; Li, L.; Liu, X. Microchim. Acta 2010, 170, 17.

(2) Zhu, X.-Q.; Zhang, M.-T.; Yu, A.; Wang, C.-H.; Cheng, J.-P. J. Am. Chem. Soc. 2008, 130, 2501.

(3) Yang, D.; Fokas, D.; Li, J.; Yu, L.; Baldino, C. M. Synthesis 2005, 47.

(4) Lee, C. K.; Lee, I. S. H. Heterocycles 2009, 78, 425. 
(5) APEX2 is a Bruker AXS crystallographic software package for single crystal data collection, reduction and preparation.

(6) Sheldrick, G. M. SHELXL-2014, Crystallographic software package, Bruker AXS, Inc., Madison, Wisconsin, USA.

(7) Nagata, T.; Tanaka, K. Bull. Chem. Soc. Jpn. 2002, 75, 2469.

(8) Jones, R. A.; Karatza, M.; Voro, T. N.; Civeir, P. U.; Franck, A.; Ozturk, O.; Seaman, J. P.; Whitmore, A. P.; Williamson, D. J. Tetrahedron 1996, 52, 8707.

(9) PLATON was written by Professor Anthony J. Spek, Bijvoet Centre for Biomolecular Research. Current versions of PLATON for Windows are available from Professor Louis J. Farrugia, Department of Chemistry of Glasglow at www.chem.gla.ac.uk/ louis/software/.

(10) Van Der Sluis, P.; Spek, A. L. Acta Crystallogr. Sect. A 1990, 46, 194.

(11) Brouwer, A. M. Pure Appl. Chem. 2011, 83, 2213.

(12) Würth, C.; Grabolle, M.; Pauli, J.; Spieles, M.; Resch-Genger, U. Nat. Protoc. 2013, 8, 1535.

(13) Fischer, M.; Georges, J. Chem. Phys. Lett. 1996, 260, 115.

(14) Neese, F. Wiley Interdiscip. Rev. Comput. Mol. Sci. 2012, 2, 73.

(15) Becke, A. D. J. Chem. Phys. 1986, 84, 4524.

(16) Becke, A. D. J. Chem. Phys. 1993, 98, 5648.

(17) Lee, C.; Yang, W.; Parr, R. G. Phys. Rev. B 1988, 37, 785.

(18) Schäfer, A.; Horn, H.; Ahlrichs, R. J. Chem. Phys. 1992, 97, 2571.

(19) Schäfer, A.; Huber, C.; Ahlrichs, R. J. Chem. Phys. 1994, 100, 5829.

(20) Weigend, F.; Ahlrichs, R. Phys. Chem. Chem. Phys. 2005, 7, 3297.

(21) Neese, F.; Wennmohs, F.; Hansen, A.; Becker, U. Chem. Phys. 2009, 356, 98.

(22) Kossmann, S.; Neese, F. Chem. Phys. Lett. 2009, 481, 240.

(23) Neese, F. J. Comput. Chem. 2003, 24, 1740.

(24) Eichkorn, K.; Treutler, O.; Öhm, H.; Häser, M.; Ahlrichs, R. Chem. Phys. Lett. 1995, 240, 283.

(25) Eichkorn, K.; Treutler, O.; Öhm, H.; Häser, M.; Ahlrichs, R. Chem. Phys. Lett. 1995, 242, 652.

(26) Eichkorn, K.; Weigend, F.; Treutler, O.; Ahlrichs, R. Theor. Chem. Acc. 1997, 97, 119.

(27) Klamt, A.; Schüürmann, G. J. Chem. Soc. Perkin Trans. II 1993, 799.

(28) Allouche, A.-R. J. Comput. Chem. 2011, 32, 174. 